\title{
Journal of

\section{Development and Pharmacological Characterization of Selective Blockers of 2-Arachidonoyl Glycerol Degradation with Efficacy in Rodent Models of Multiple Sclerosis and Pain}

Margherita Brindisi, ${ }^{\dagger}$ Samuele Maramai, ${ }^{\dagger}$ Sandra Gemma, ${ }^{\dagger}$ Simone Brogi, ${ }^{\dagger}$ Alessandro Grillo, ${ }^{\dagger}$ Lorenzo Di Cesare Mannelli, ${ }^{\|}$Emanuele Gabellieri, ${ }^{\dagger}$ Stefania Lamponi, ${ }^{\dagger}$ Simona Saponara, ${ }^{\ddagger}$ Beatrice Gorelli, ${ }^{\ddagger}$ Daniele Tedesco, ${ }^{\S}$ Tommaso Bonfiglio, ${ }^{\perp}$ Christophe Landry, ${ }^{\#}$ Kwang-Mook Jung, ${ }^{\nabla}$ Andrea Armirotti, ${ }^{\bigcirc}$ Livio Luongo, Alessia Ligresti, ${ }^{\text {Pl }}$ Fabiana Piscitelli, ${ }^{\text {II }}$ Carlo Bertucci, ${ }^{\S}$ Marie-Pierre Dehouck, ${ }^{\#}$ Giuseppe Campiani, ${ }^{* \dagger \dagger}$ Sabatino Maione, ${ }^{\bullet}$ Carla Ghelardini, ${ }^{\|}$Anna Pittaluga, ${ }^{\perp,+}$ Daniele Piomelli, ${ }^{\nabla}$ Vincenzo Di Marzo, ${ }^{\mathrm{TI}}$ and Stefania Butini ${ }^{\dagger}$

${ }^{\dagger}$ European Research Centre for Drug Discovery and Development (NatSynDrugs), University of Siena, via Aldo Moro 2, I-53100 Siena, Italy

${ }^{\ddagger}$ Department of Life Sciences, University of Siena, via Aldo Moro 2, I-53100 Siena, Italy

${ }^{\S}$ Department of Pharmacy and Biotechnology Alma Mater Studiorum, University of Bologna, Via Belmeloro 6, 40126 Bologna, Italy

"Department of Neuroscience, Psychology, Drug Research and Child Health, Section of Pharmacology and Toxicology,

University of Firenze, V.le G. Pieraccini 6, 50139 Firenze, Italy

${ }^{\perp}$ Department of Pharmacy, Section of Pharmacology and Toxicology, University of Genova, Viale Cembrano 4, Genova, 16148, Italy

\#Laboratoire de la Barrière Hémato-Encéphalique (LBHE), University of Artois, EA 2465, F62300 Lens, France

${ }^{\nabla}$ Department of Anatomy and Neurobiology, University of California, Irvine, California 92617, United States

ODrug Discovery and Development, Istituto Italiano di Tecnologia, 16163 Genova, Italy

Endocannabinoid Research Group, Department of Experimental Medicine, Division of Pharmacology "L. Donatelli”, Second University of Napoli, 80138 Napoli, Italy

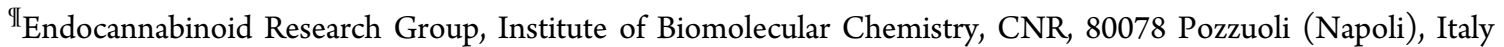

${ }^{+}$Center of Excellence for Biomedical Research, University of Genova, Viale Benedetto XV, 16132 Genova, Italy

Supporting Information
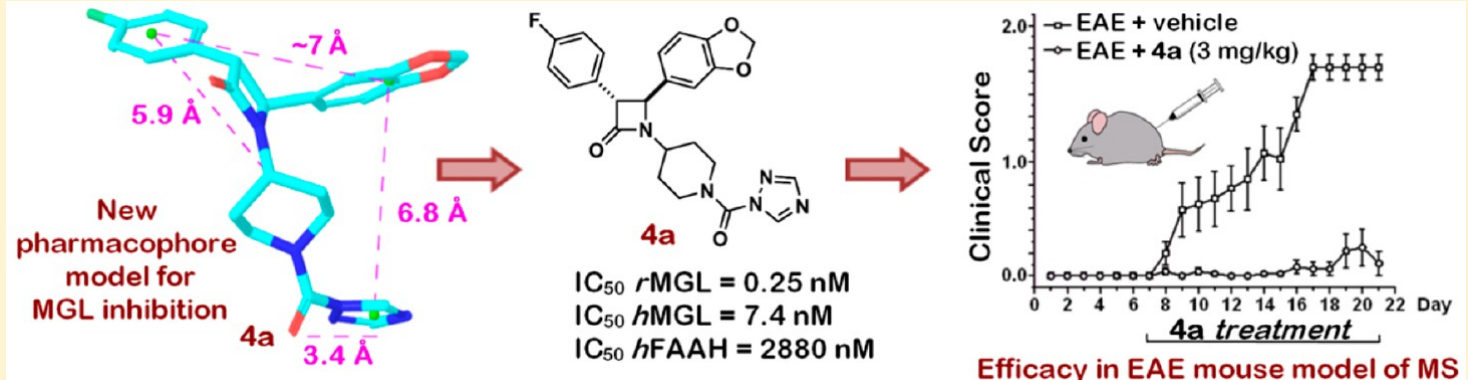

ABSTRACT: We report the discovery of compound 4a, a potent $\beta$-lactam-based monoacylglycerol lipase (MGL) inhibitor characterized by an irreversible and stereoselective mechanism of action, high membrane permeability, high brain penetration evaluated using a human in vitro blood-brain barrier model, high selectivity in binding and affinity-based proteomic profiling assays, and low in vitro toxicity. Mode-of-action studies demonstrate that 4a, by blocking MGL, increases 2-arachidonoylglycerol and behaves as a cannabinoid (CB1/CB2) receptor indirect agonist. Administration of $\mathbf{4 a}$ in mice suffering from experimental autoimmune encephalitis ameliorates the severity of the clinical symptoms in a CB1/CB2-dependent manner. Moreover, 4a produced analgesic effects in a rodent model of acute inflammatory pain, which was antagonized by CB1 and CB2 receptor antagonists/inverse agonists. 4a also relieves the neuropathic hypersensitivity induced by oxaliplatin. Given these evidence, $\mathbf{4 a}$, as MGL selective inhibitor, could represent a valuable lead for the future development of therapeutic options for multiple sclerosis and chronic pain. 


\section{INTRODUCTION}

Multiple sclerosis (MS) is a neuroinflammatory autoimmune disease characterized by demyelination and axonal damage leading to loss of cerebral functions. ${ }^{1}$ The treatment landscape of MS includes several anti-inflammatory agents and monoclonal antibodies for immunotherapy. Besides demyelination and inflammation, thought to play the major role in MS progression, central neuronal defects also occur and have been associated with the onset of symptoms such as spasticity and pain.

In the past few years, an increasing body of evidence has suggested that cannabinoids may have beneficial effects on the symptoms of MS. ${ }^{2}$ More recently, attention has focused on small molecules modulating the endocannabinoid system, although more investigation is needed to prove whether endocannabinoid system modulation may represent a valuable therapeutic option to successfully reverse the clinical progression of MS. ${ }^{3}$ In fact, therapeutic inhibition of endocannabinoid degrading enzymes increases the endocannabinoids (ECs) tissue levels and is less likely to cause psychoactive effects than direct agonism of cannabinoid receptor 1 (CB1) while maintaining other beneficial effects of $\mathrm{CB} 1 / 2$ receptors activation. ${ }^{4-6}$

ECs such as Anandamide (AEA) and 2-arachidonoyl-sn-glycerol (2-AG) are signaling lipids that exert their biological actions by interacting with cannabinoid receptors (CBRs); ${ }^{7}$ they modulate multiple physiological processes including pain, inflammation, appetite, memory, and emotion. ${ }^{8}$ In the brain, $2-A G$ is produced by diacylglycerol lipases and it is deactivated through monoacylglycerol lipase (MGL)-mediated hydrolysis. Because of its prominent role in 2-AG catabolism, selective inactivation of MGL represents an attractive approach for eliciting the desirable effects of indirect CBR activation. MGL is a serine hydrolase with a catalytic triad represented by Ser122, His269, and Asp239.' Inhibitors of 2-AG degradation have been developed such as the carbamate biphenyl-3-ylcarbamic acid cyclohexyl ester (URB602), ${ }^{10-12}$ the tetrahydrolipstatin $(S)-1-((2 S, 3 S)-3-$ hexyl-4-oxooxetan-2-yl)tridecan-2-yl 2-formamidoacetate (OMDM169), ${ }^{13}$ the 4-(bis-benzo[1,3] dioxol-5-ylhydroxy-methyl)piperidine-1-carboxylic acid 4-nitro-phenyl ester 1 (JZL184), ${ }^{14}$ the ureidic 4-(bis(4-fluorophenyl)methyl)piperazin-1-yl)(1H-1,2,4-triazol-1-yl)methanone 2 (SAR629), ${ }^{15}$ and their analogue (4-(bis(benzo[ $d][1,3]$ dioxol-5-yl)methyl)piperidin-1-yl)(1H-1,2,4-triazol-1-yl)methanone 3 (JJKK-048). ${ }^{16}$

Despite the variety of MGL inhibitors available, the structural diversity of chemical templates explored to date remains poor. Compound 1, which shares with most MGL inhibitors the diphenylmethane core, is frequently used as experimental tool but it exhibits only submicromolar activity against the human MGL ( $h$ MGL) enzyme.

We describe herein the development of a set of $\beta$-lactam-based inhibitors $(\mathbf{4} \mathbf{a}-\mathbf{h}$, Chart 1$)$ of human MGL which led to the identification of $\mathbf{4 a}$ as the prototypic compound of this class of analogues. 4a was characterized as a novel, ultrapotent $h \mathrm{MGL}$ inhibitor, with high selectivity toward the AEAinactivating enzyme, fatty acid amide hydrolase (FAAH), other serine hydrolases from the rat brain proteome, and CBRs. The unique profile of this prototypic inhibitor combines selectivity, potency, and favorable pharmacokinetic properties, highlighting its potential as a novel MGL inhibitor for further development (Table 1). As expected for a potent and selective MGL inhibitor, in vivo administration of $\mathbf{4 a}$ reduced the clinical severity of the disease in mice suffering from experimental autoimmune encephalomyelitis (EAE), a rodent demyelinating disease model. ${ }^{17}$
Chart 1. Representative Diphenylmethane Inhibitors (Compounds 1-3) and General Structure of Title Compounds $4 a-h$
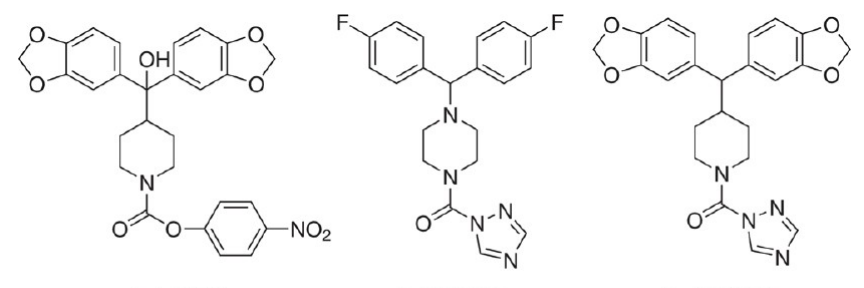

1, JZL184

2, SAR629

3, JJKK048

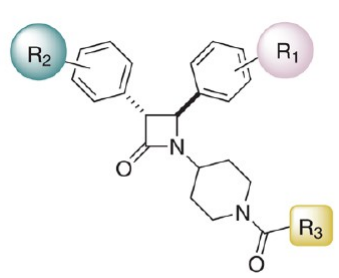

4a-h, as defined in Scheme 1 and Table 1

In vivo tests confirmed the analgesic profile of $\mathbf{4 a}$ in mouse models and evidenced a clear-cut dependence of its pharmacological efficacy upon the increased 2-AG levels and subsequent indirect CBRs modulation. Remarkably, the efficacy of 4a further supports the hypothesis ${ }^{2}$ of a tight intersection between the endocannabinoid system and MS.

\section{CHEMISTRY}

Synthesis of compounds $( \pm)-,(+)-$, and $(-)-4 a,( \pm)-4 b-h$, $( \pm)-5 a-e,( \pm)-6 a-e,( \pm)-7,( \pm)-8$, and 9 is reported in Schemes 1-3.

Aldehydes $10 a-c$ were reacted with 4-amino-1-benzylpiperidine to form the intermediate imines $11 \mathbf{a}-\mathbf{c}$. These latter were subjected to the Staudinger reaction ${ }^{18}$ using the suitable phenylacetic acid, in the presence of triphosgene, to obtain the $\beta$-lactam systems $( \pm)-5 a-e$ in the trans configuration. The benzyl groups of $( \pm)-5 a-e$ were then cleaved by means of a palladium catalyzed hydrogenation leading to free amines $( \pm)-6 \mathbf{a}-\mathbf{e}$. Amines $( \pm)-6 a-e$ were reacted with $1 H-1,2,4$-triazole in the presence of phosgene and DMAP, providing final compound $( \pm)-\mathbf{4 a}, \mathbf{e}-\mathbf{h}$. Enantiomerically pure amines $(3 R, 4 S)-(+)-6 \mathbf{a}$ and $(3 S, 4 R)$ (-)-6a, separated by HPLC as reported in the Supporting Information, were also submitted to final reaction with $1 H-1,2,4-$ triazole in the presence of phosgene, leading to enantiomerically pure final compounds $(3 R, 4 S)-(+)-4 \mathbf{a}$ and $(3 S, 4 R)-(-)-4 \mathbf{a}$, respectively. Compounds $\mathbf{4 b}, \mathbf{4 c}$, and $4 \mathrm{~d}$ were prepared by reaction of amine $( \pm)$-6a with 4-nitrophenyl chloroformate, 1,1carbonyldiimidazole, 1,1,1,3,3,3-hexafluoroisopropanol, and triphosgene, respectively (Scheme 1).

Compound $( \pm)-12$ was prepared by alane reduction of compound $( \pm)-5 \mathbf{a}$. Subsequent hydrogenation and treatment of the resulting amine $( \pm)$-13 with $1 \mathrm{H}-1,2,4$-triazole, phosgene, and DMAP led to derivative ( \pm )-7 (Scheme 2).

Catalyst 16 (Scheme 3), used for the diastereoselective synthesis of the trans-3,4-diarylsubstituted $\beta$-lactam system, was prepared by refluxing 14 with 3-amino-1-propanol in chlorobenzene and successive treatment of the intermediate $\mathbf{1 5}$ with mesyl chloride in the presence of $N, N$-diisopropylethylamine (DIPEA). ${ }^{19}$ Meanwhile, imine 17, obtained by heating at reflux 10a with 4-toluenesulfonamide in absolute ethanol, was subjected to the cyclization reaction ${ }^{20}$ using 4-fluorophenylacetic acid, in the presence of tosyl chloride and catalyst 16, obtaining the 
Scheme 1. Synthesis of Title Compounds $4 a-h^{a}$
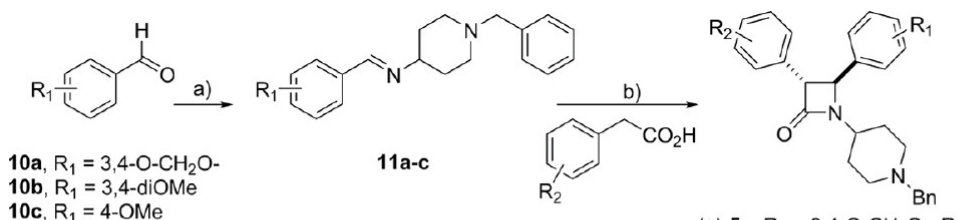

$( \pm)-5 a, \mathrm{R}_{1}=3,4-\mathrm{O}-\mathrm{CH}_{2} \mathrm{O}-, \mathrm{R}_{2}=4-\mathrm{F}$

( \pm -5b, $\mathrm{R}_{1}=3,4-\mathrm{O}-\mathrm{CH}_{2} \mathrm{O}-, \mathrm{R}_{2}=4-\mathrm{OMe}$

$( \pm)-5 c, R_{1}=3,4-d i O M e, R_{2}=4-O M e$

$( \pm)-5 d, R_{1}=R_{2}=3,4-d i O M e$

$( \pm)-5 e, R_{1}=R_{2}=4-O M e$
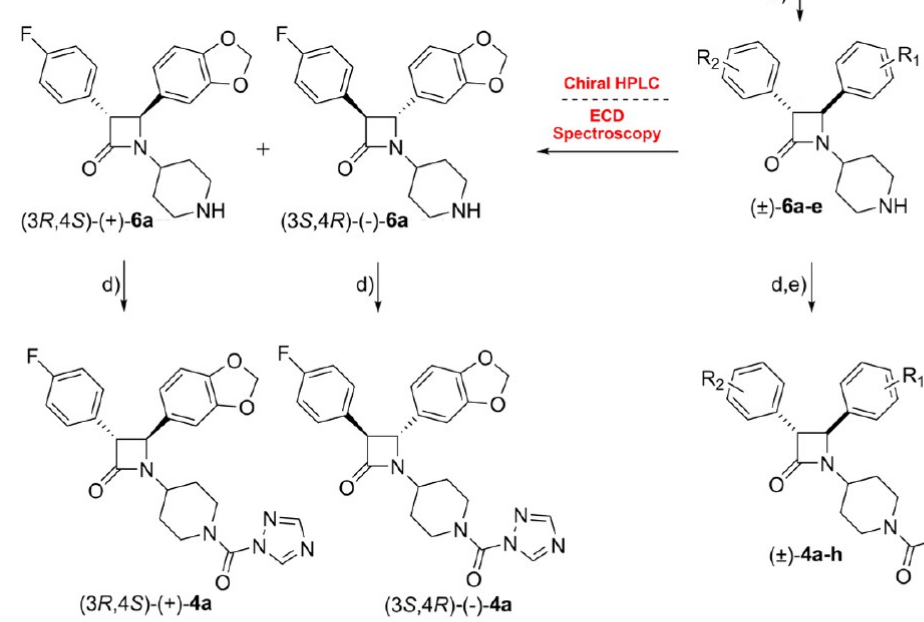

d)

d,e)

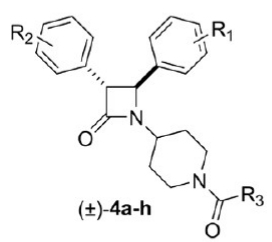

$(3 S, 4 R)-(-)-4 a$

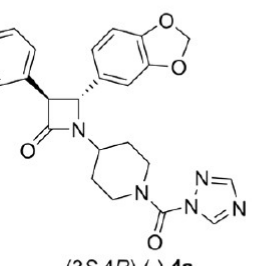

\begin{tabular}{|c|c|c|c|}
\hline & $\mathrm{R}_{1}$ & $\mathrm{R}_{2}$ & $\mathrm{R}_{3}$ \\
\hline $4 \mathbf{a}$ & $3,4-\mathrm{O}-\mathrm{CH}_{2} \mathrm{O}-$ & $4-\mathrm{F}$ & $1 H$-1,2,4-triazolyl \\
\hline $4 b$ & $3,4-\mathrm{O}-\mathrm{CH}_{2} \mathrm{O}-$ & $4-\mathrm{F}$ & 4-nitrophenoxy \\
\hline $4 c$ & $3,4-\mathrm{O}-\mathrm{CH}_{2} \mathrm{O}-$ & $4-\mathrm{F}$ & $1 \mathrm{H}$-imidazolyl \\
\hline $4 d$ & $3,4-\mathrm{O}-\mathrm{CH}_{2} \mathrm{O}-$ & $4-\mathrm{F}$ & hexafluoropropan-2- \\
\hline $4 e$ & $3,4-\mathrm{O}-\mathrm{CH}_{2} \mathrm{O}-$ & 4-OMe & 1H-1,2,4-triazolyl \\
\hline $4 \mathrm{f}$ & 3,4-diOMe & 4-OMe & $1 \mathrm{H}-1,2,4$-triazolyl \\
\hline $4 \mathrm{~g}$ & 3,4-diOMe & 3,4-diOMe & $1 H$-1,2,4-triazolyl \\
\hline $4 h$ & 4-OMe & 4-OMe & $1 H-1,2,4$-triazolyl \\
\hline
\end{tabular}

${ }^{a}$ Reagents and conditions: (a) 4-amino-1-benzylpiperidine, EtOH, $80{ }^{\circ} \mathrm{C}, 12 \mathrm{~h}$; (b) triphosgene, dry DCM, $50{ }^{\circ} \mathrm{C}, 0.5 \mathrm{~h}, \mathrm{TEA}, 50{ }^{\circ} \mathrm{C}, 12 \mathrm{~h}$; (c) $\mathrm{H}_{2}, \mathrm{Pd} / \mathrm{C} 10 \%, \mathrm{MeOH}, 25{ }^{\circ} \mathrm{C}, 2 \mathrm{~h}$; (d) $1 \mathrm{H}$-1,2,4-triazole, phosgene (20\% in toluene), DMAP, dry DCM, $25{ }^{\circ} \mathrm{C}, 12 \mathrm{~h}$; (e) for 4b, 4-nitrophenyl chloroformate, TEA, dry DCM, $25{ }^{\circ} \mathrm{C}, 12 \mathrm{~h}$; for $4 \mathrm{c}, 1,1$-carbonyldiimidazole, dry DCM, $25{ }^{\circ} \mathrm{C}, 12 \mathrm{~h} ;$ for $4 \mathrm{~d}, 1,1,1,3,3,3-$ hexafluoroisopropanol, triphosgene, DIPEA, dry DCM, $25^{\circ} \mathrm{C}, 12 \mathrm{~h}$; for $\mathbf{4 a}, \mathbf{e}-\mathbf{h}, 1 \mathrm{H}-1,2,4-$ triazole, phosgene (20\% in toluene), DMAP, dry DCM, $25^{\circ} \mathrm{C}, 12 \mathrm{~h}$.

$N$-tosylated trans- $\beta$-lactam ( \pm$)$-18. This latter was treated with a solution of $\mathrm{SmI}_{2}$ in tetrahydrofuran to give the final compound $( \pm)-8$. Compound 9 was prepared by reaction of piperidine (19) with $1 H-1,2,4$-triazole and phosgene in the presence of DMAP.

To evaluate the stereoselectivity of the interaction of $( \pm)-4 a$ with $h$ MGL (see Table 1 in next paragraph), we resolved the racemic mixture of amine ( \pm )-6a by using chiral HPLC (see Supporting Information). The two amines, (+)-6a and (-)-6a, showing an optical purity $>98 \%$ (Supporting Information, Figure S2), underwent the final reaction to yield the two enantiomers of $4 a$. Enantiomers (+)-6a and (-)-6a yielded (+)-4a and (-)-4a, respectively. The absolute configuration of (+)-trans-6a was established by means of electronic circular dichroism (ECD) spectroscopy combined with time-dependent density functional theory (TD-DFT) calculations of the theoretical chiroptical properties of $(3 R, 4 S)-6 a^{21}$ As shown in Figure 1, the theoretical UV and ECD spectra of $(3 R, 4 S)-6$ a are in agreement with the experimental spectra of $(+)$-trans-6, allowing us to assign a $(3 R, 4 S)$ configuration to $(+)-6 \mathbf{a}$ and, consequently, to $(+)-\mathbf{4 a}$.

\section{RESULTS AND DISCUSSION}

Rational Design, Structure-Activity Relationships, and Molecular Modeling Studies. The MGL-2 cocrystal structure $^{22}$ defined the structural basis for MGL inhibition. This complex also shed light on the size of the lipophilic portion of the MGL binding pocket, which is of particular interest for designing novel and selective enzyme ligands. An in-depth examination of this X-ray structure, combined with the analysis of the structural elements of other diphenylmethane inhibitors, allowed us to develop a novel 3D pharmacophore model and to rationally design innovative MGL inhibitors based on a $\beta$-lactam skeleton (Chart 1, and Figure S1 of the Supporting Information). In particular, to improve the binding properties over current inhibitors such as $\mathbf{1}$, we chose the trans-3,4-diarylsubstituted $\beta$-lactam structural motif to obtain the correct distance and reciprocal orientation of the aromatic rings (see Supporting Information for details). In this frame, the combination of the 4-fluorophenyl and the methylene-3,4-dioxyphenyl moieties provides the key hydrophobic interactions with the enzyme (Supporting Information, Figure S1) and guarantees an improved 
Scheme 2. Synthesis of Analogue $( \pm)-7^{a}$<smiles>C[13CH2][13CH3]</smiles><smiles>Fc1ccc([C@@H]2CN(C3CCN(Cc4ccccc4)CC3)[C@H]2c2ccc3c(c2)OCO3)cc1</smiles><smiles>O=C(N1CCC(N2C[C@H](c3ccc(F)cc3)[C@H]2c2ccc3c(c2)OCO3)CC1)n1cncn1</smiles><smiles>Fc1ccc([C@@H]2CN(C3CCNCC3)[C@H]2c2ccc3c(c2)OCO3)cc1</smiles>

${ }^{a}$ Reagents and conditions: (a) $\mathrm{LiAlH}_{4}, \mathrm{AlCl}_{3}$, dry $\mathrm{THF}, 0{ }^{\circ} \mathrm{C}, 45 \mathrm{~min}$ then $10 \%$ aqueous $\mathrm{NaOH}, 0{ }^{\circ} \mathrm{C}, 30 \mathrm{~min}$; (b) $\mathrm{H}_{2}, 10 \% \mathrm{Pd} / \mathrm{C}, \mathrm{MeOH}$, $25{ }^{\circ} \mathrm{C}, 2 \mathrm{~h}$; (c) $1 \mathrm{H}$-1,2,4-triazole, phosgene (20\% in toluene), DMAP, dry DCM, $25^{\circ} \mathrm{C}, 12 \mathrm{~h}$.

Scheme 3. Synthesis of $\beta$-Lactam $( \pm)-8$, and of Compound $9^{a}$
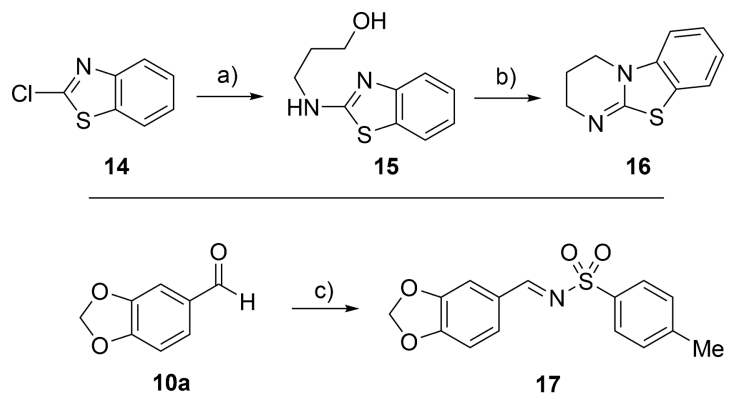

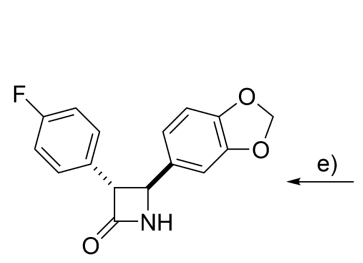

$( \pm)-8$

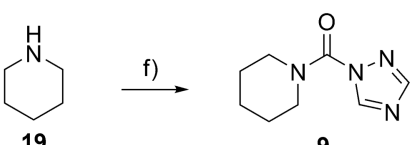

${ }^{a}$ Reagents and conditions: (a) 3-amino-1-propanol, DIPEA, chlorobenzene, $130{ }^{\circ} \mathrm{C}, 4 \mathrm{~h}$; (b) TEA, $\mathrm{MsCl}$, dry DCM, 0-25 ${ }^{\circ} \mathrm{C}, 1.5 \mathrm{~h}$ then $\mathrm{MeOH}$, TEA, $50{ }^{\circ} \mathrm{C}, 1.5 \mathrm{~h}$; (c) 4-toluensulfonamide, $\mathrm{BF}_{3} \cdot \mathrm{Et}_{2} \mathrm{O}$, dry toluene, $130{ }^{\circ} \mathrm{C}, 12 \mathrm{~h}$; (d) 4-fluorophenylacetic acid, TsCl, DIPEA, dry DCM, $0{ }^{\circ} \mathrm{C}, 30 \mathrm{~min}$ then 16, DIPEA, $25^{\circ} \mathrm{C}, 5 \mathrm{~h}$; (e) $\mathrm{SmI}_{2} 0.1 \mathrm{~N}$ solution in THF, dry THF, $25{ }^{\circ} \mathrm{C}, 15 \mathrm{~min}$; (f) $1 \mathrm{H}$-1,2,4-triazole, phosgene (20\% in toluene), DMAP, dry DCM, $25^{\circ} \mathrm{C}, 12 \mathrm{~h}$.

drug-like profile. The diaryl $\beta$-lactam system of compounds $\mathbf{4 a - h}$ represents a novelty in the field of MGL inhibition because the potent inhibitors so far described (compounds 1-3) all share a diphenylmethane-based structure.

The experimental data shown in Table 1 confirmed that the $\beta$-lactam is a key substructure for potent and selective MGL
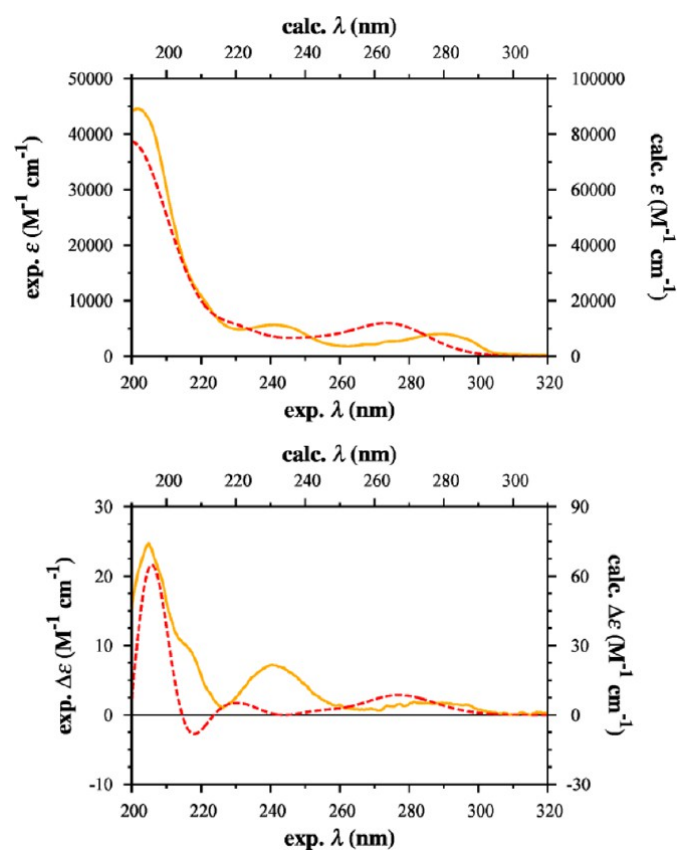

Figure 1. Absolute configuration determination of compound 6a. Experimental UV and ECD spectra of (+)-trans-6a (solid line) compared to the $\mathrm{PBE} 0 / \mathrm{TZ2P} / / \mathrm{B} 97 \mathrm{D} / \mathrm{TZ2P}$ calculated spectra of $(3 R, 4 S)-6 a$ (dashed line). Computational details are given in Experimental Section and Supporting Information.

inhibition. When compound $\mathbf{4 a}$ was tested in vitro for its ability to inhibit human and rat MGL, it resulted in being a very potent inhibitor of $h \mathrm{MGL}\left(\mathrm{IC}_{50}=7.4 \mathrm{nM}\right.$, Table 1$)$ and a picomolar inhibitor of rat MGL ( $r$ MGL, $\left.\mathrm{IC}_{50}=250 \mathrm{pM}\right)$. Selectivity toward human recombinant FAAH was measured, and 4a proved to be more than 380 -fold selective over human FAAH ( $h$ FAAH) (Table 1). Notably, the two enantiomers showed a stereoselective interaction with $h \mathrm{MGL}$ (Table 1 ), the eutomer $(3 R, 4 S)$ $(+)-4 a$ being nearly 7 times more potent than the distomer $(3 S, 4 R)-(-)-4 a$. The selectivity versus $h$ FAAH was maintained, with both enantiomers still being highly selective for $h \mathrm{MGL}$ (Table 1).

Further in vitro tests revealed that $\mathbf{4 a}$ does not significantly interact $\left(\mathrm{IC}_{50}>10 \mu \mathrm{M}\right)$ with either $\mathrm{CB} 1$ or $\mathrm{CB} 2$ receptors in displacement assays carried out with a high affinity radiolabeled ligand of such receptors. A time-course experiment showed that 4a inhibits $h \mathrm{MGL}$ with an $\mathrm{IC}_{50}=195.8 \mathrm{nM}$ (Table 2) when the assay was conducted without the standard $10 \mathrm{~min}$ preincubation, thus suggesting an irreversible mechanism of action.

We developed and tested a small set of analogues of $4 a(4 b-h$, Table 1) in order to investigate: (i) the role played by the leaving group linked to the piperidine ring $(\mathbf{4 b}-\mathbf{d}$, Table 1$)$ and (ii) the effect of a small number of focused substitutions aimed at modifying steric hindrance and electronic properties of the aromatic systems placed on the $\beta$-lactam skeleton $(\mathbf{4} \mathbf{e}-\mathbf{h}$, Table 1$)$.

When studying the mechanism of action of irreversible MGL inhibitors, we applied the concept advanced by Aaltonen and coworkers ${ }^{16}$ according to whom the effects of the leaving group are strictly dependent upon its physicochemical properties, although steric hindrance may also play a role. In fact, we found that the effect on potency seems to be related to the $\mathrm{p} K_{\mathrm{a}}$ of the leaving group's conjugated acid (ideal $\mathrm{p} K_{\mathrm{a}} \sim 10$ ). Accordingly, the best profile among compounds $\mathbf{4 a}-\mathbf{d}$ was achieved with the triazole $\left(\mathrm{p} K_{\mathrm{a}}=10\right)$, while the imidazole $\left(\mathrm{p} K_{\mathrm{a}}=14\right)$ provided a 1500 -fold 
Table 1. Inhibition Activity of Compounds $4 \mathrm{a}-\mathrm{h}, 5 \mathrm{a}, 6 \mathrm{a}$, and 7-9 on Human and Rat MGL Enzymes (IC $\left.\mathrm{F}_{50}, \mathrm{nM}\right)$ and on Human or Rat FAAH Enzymes $\left(\mathrm{IC}_{50}, \mathrm{nM}\right)^{a}$
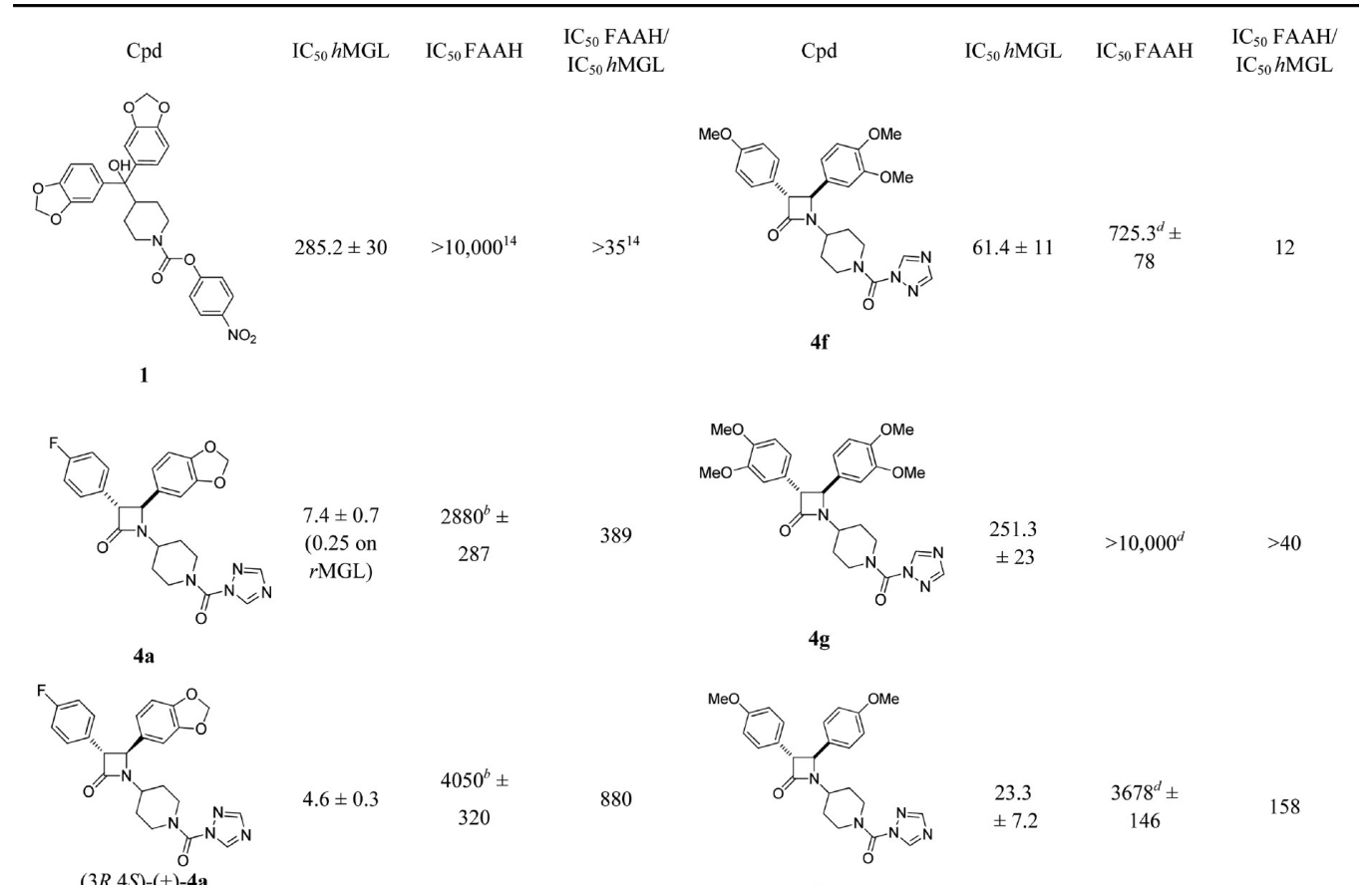

$4 h$<smiles></smiles>
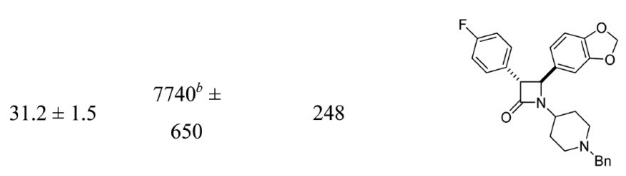

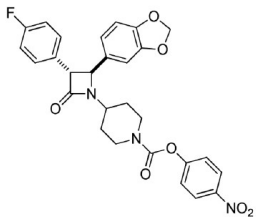
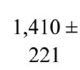

$>10,000^{b}$

$4 b$<smiles>O=C(c1ccncc1)N1CCC(N(c2ccc3c(c2)OCO3)C2c3ccc(F)cc3C2C(=O)n2ccnc2)CC1</smiles>

$5 \mathbf{a}$

$>10,000$<smiles>O=C1C(c2ccc3c(c2)OCO3)C(=O)N(C2CCNCC2)C1c1ccc(F)cc1</smiles>

$>10,000$

$6 a$<smiles>O=C(c1ccc2c(c1)OCO2)N1CCC(N2CC(c3ccc(F)cc3)C2)CC1</smiles>

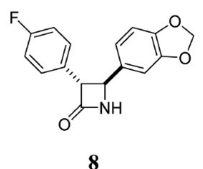

10,000

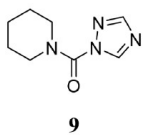

$376 \pm 154$
$>10,000$

$4 \mathrm{c}$<smiles>O=C(OC(F)(F)C(F)(F)F)N1CCC(N2CC(c3ccc4c(c3)OCO4)C(c3ccc(F)cc3)C2=O)CC1</smiles>

$97.5^{c} \pm$

20.7

$>50,000^{d}$

$>513$

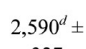

327

196

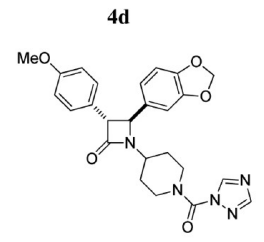

${ }^{a_{T}}$ Tests were performed as described in the Experimental Section; values are means of three experiments and all SD are within $10 \% .{ }^{b} h \mathrm{FAAH} \mathrm{IC}_{50}$. ${ }^{c} \mathrm{COS}$ cells MGL IC $50 \cdot{ }^{d} \mathrm{FAAH} \mathrm{IC} \mathrm{IO}_{50}$. 
Table 2. Inhibition Activity of Reference Compound 1 and Compounds $4 \mathrm{a},(3 R, 4 S)-(+)-4 \mathrm{a}$, and $(3 S, 4 R)-(-)-4 \mathrm{a}$ on Human MGL $\left(\mathrm{IC}_{50}, \mathrm{nM}\right)^{a}$

$\begin{array}{lc} & \mathrm{IC}_{50} h \mathrm{MGL}(\mathrm{nM}) \\ \mathbf{1} & 4440 \pm 268 \\ \mathbf{4 a} & 195.8 \pm 9 \\ (3 R, 4 S)-(+)-\mathbf{4 a} & 104.4 \pm 12 \\ (3 S, 4 R)-(-)-\mathbf{4 a} & 728.5 \pm 21\end{array}$

${ }^{a}$ The effect of the compounds on MGL activity was measured after a $20 \mathrm{~min}$ of incubation with the enzyme in the presence of the specific substrate, as described in the Experimental Section; values are means of three experiments and all SD are within $10 \%$.

reduction in potency ( $\mathbf{4 b}$ vs $\mathbf{4 a}$, Table 1 ), the $p$-nitrophenoxy group (1) $\left(\mathrm{p} K_{\mathrm{a}}=7\right)$ displayed a 200 -fold drop of potency (4c vs $\left.4 \mathrm{a}\right)$, and the hexafluoroisopropyl alcohol $\left(\mathrm{p} K_{\mathrm{a}}=9\right)$ gave an analogue (4d) 17 times less potent than 4 a.

The modification of steric hindrance and electronic properties of the aromatic systems placed on the $\beta$-lactam skeleton was also crucial for potency and selectivity of our MGL inhibitors. The replacement of the 4-fluoro of 4a with a methoxy group led to inhibitor $4 \mathbf{e}$ with a slight loss of inhibitory potency $\left(\mathrm{IC}_{50}=\right.$ 13.2 nM, Table 1). Compound 4f, in which the methylene-3,4dioxyphenyl moiety was replaced by a dimethoxyphenyl system, resulted in a 10 times less potent analogue $\left(\mathrm{IC}_{50}=61.4 \mathrm{nM}\right.$, Table 1) and displayed the lowest degree of selectivity toward FAAH $\left(\mathrm{IC}_{50} r \mathrm{FAAH} / \mathrm{IC}_{50} h \mathrm{MGL}=12\right)$. Substitution (with methoxy groups) at para and meta positions on both the aromatic rings $(\mathbf{4 g})$ was detrimental and led to a sensible decrease of MGL inhibition potency $\left(\mathrm{IC}_{50}=251.3 \mathrm{nM}\right)$. By contrast, a decreased steric hindrance, by substitution (with methoxy groups) at the para positions only (4h), triggered a partial recovery of inhibitory potency $\left(\mathrm{IC}_{50}=23.3 \mathrm{nM}\right)$.

Taken together, these studies point out to the 4-F-phenyl system at C3 of the $\beta$-lactam skeleton and a methylene-3,4dioxyphenyl moiety at $\mathrm{C} 4$, combined to the triazole system, (4a) as the optimal structural arrangement for both potency and selectivity.

Further studies were dedicated to gain insight into the mechanism of action of $\mathbf{4 a}$. We applied a molecular deconstruction procedure aimed at defining the essential structural determinants contributing to the high potency of $\mathbf{4 a}$ (Chart 2). To this aim, synthetic intermediates $\mathbf{5 a}$ and $\mathbf{6 a}$ were also tested in order to

Chart 2. Molecular Deconstruction Units of Compound 4a

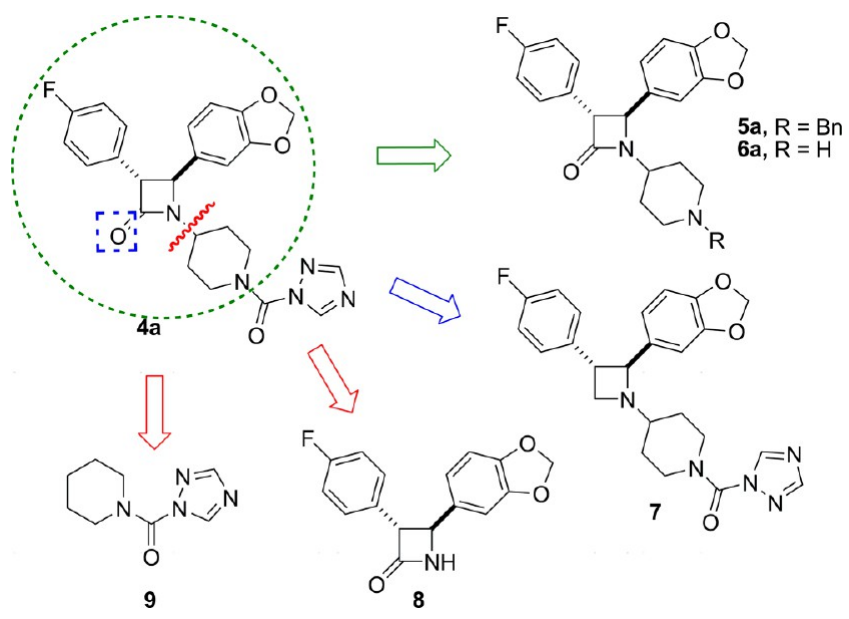

assess the importance of the leaving triazole group. In line with the hypothesized irreversible mechanism of action, both amines 5a and 6a lacked inhibitory activity toward MGL (Table 1). We also explored the role of the azetidinone system by synthesizing the azetidine 7. This compound, displaying a 2-fold drop in inhibitory potency $\left(\mathrm{IC}_{50}=376 \mathrm{nM}\right)$, underlined the pivotal role played by the $\beta$-lactam amide carbonyl (Table 1$)$. Finally, the isolated 3,4-trans-diaryl- $\beta$-lactam system (8) and the piperidine triazole urea disconnection unit 9 were found to be extremely weak MGL inhibitors $\left(\mathrm{IC}_{50}>10 \mu \mathrm{M}\right)$. Overall, molecular deconstruction confirmed the original design hypothesis leading to $4 \mathbf{a}$ as a synergistic combination of key structural elements for the fine-tuning of potency.

The interaction of $\mathbf{4 a}$ with $r \mathrm{MGL}$ was also studied by combining top-down and bottom-up proteomics experiments (Figure 2) (see Supporting Information for details). These
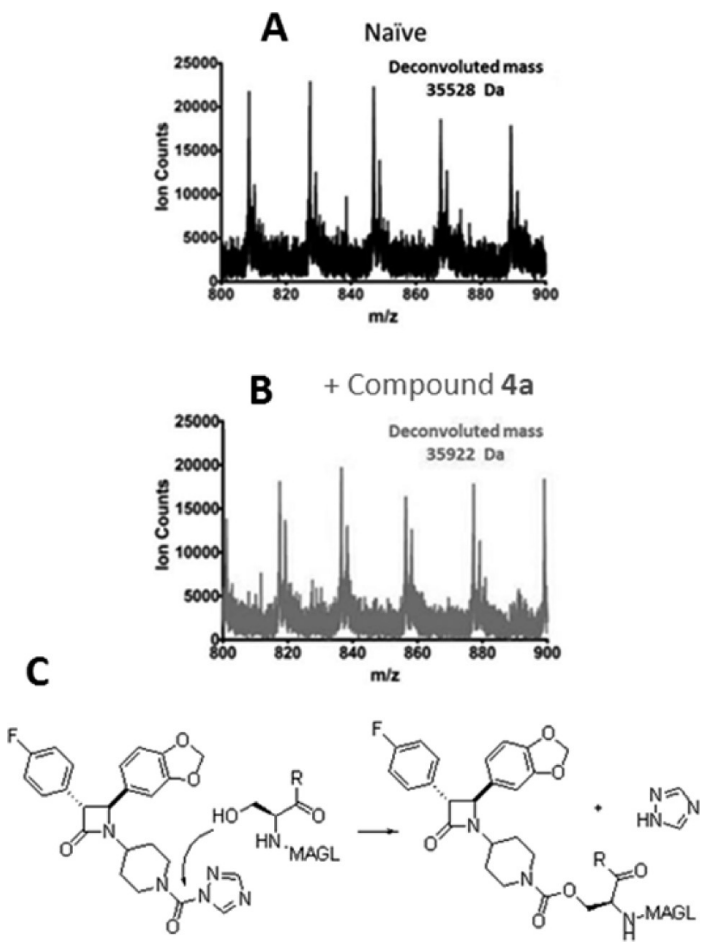

Figure 2. Investigation of the mechanism of action of compound $4 a$ by high resolution mass spectrometry experiments. Multiply charged mass spectra of intact $r$ MGL naive (A) or incubated with 4a (B) and nucleophilic attack of Ser122 on the urea moiety of 4a, with formation of a carbamate $(\mathrm{C})$.

studies, which were consistent with a covalent interaction of $\mathbf{4 a}$ with MGL, also indicated that the covalent MGL-4a adduct was achieved with 1:1 stoichiometry, under the assay conditions. Furthermore, the outcome of the bottom-up proteomic analyses, performed to map the binding site of $\mathbf{4 a}$ in MGL, indicated that the carbamoyl adduct of the tryptic peptide with $4 a$ (Figure 2C) contains six serine residues, including the catalytic Ser122. Tandem mass analysis allowed us to unequivocally assign Ser 122 as the site of modification induced by the nucleophilic attack on the urea moiety of $\mathbf{4 a}$ (Figures S2-S5; see Supporting Information for details).

The stereoselective interaction of $\mathbf{4 a}$ with $h \mathrm{MGL}$ was investigated by docking studies (Glide, version 5.7, Schrödinger, LLC, New York, NY, 2011). The eutomer (3R,4S)-4a shows a different pattern of interactions with respect to the distomer 


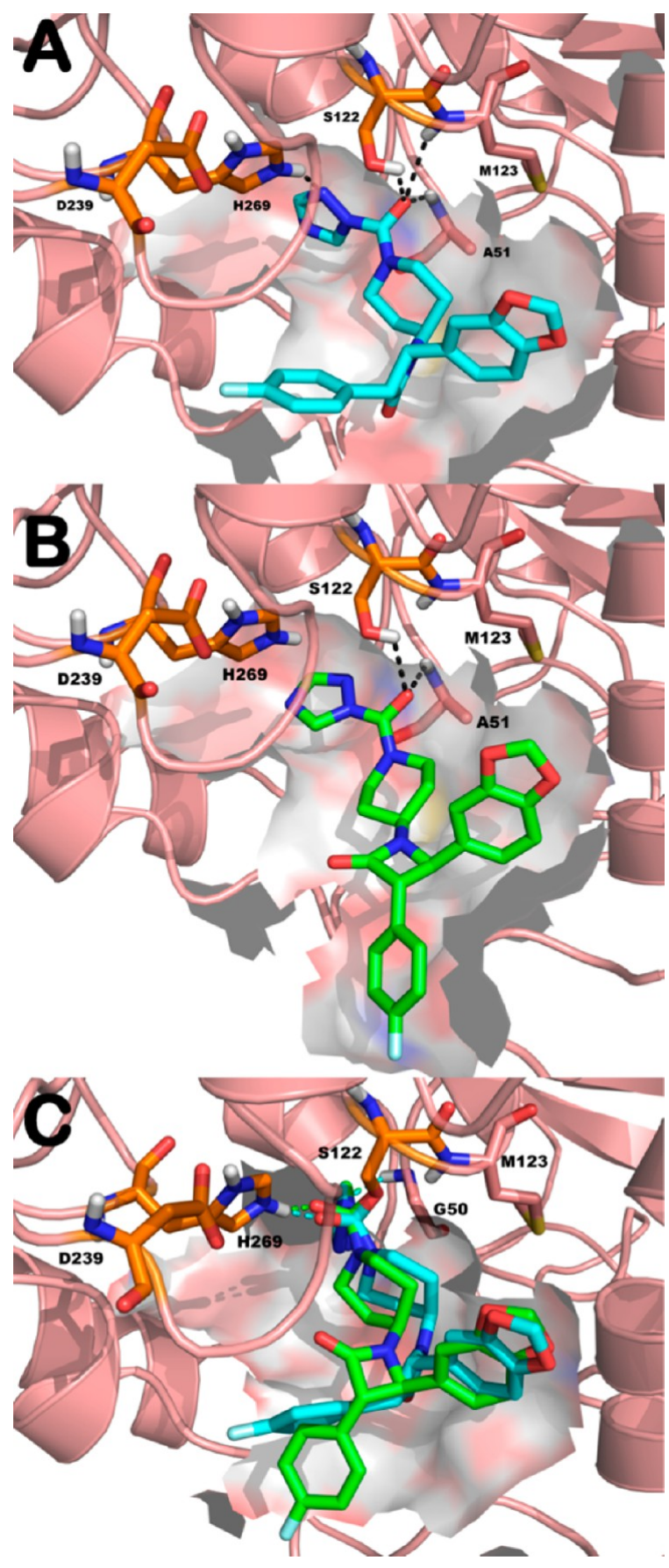

Figure 3. Molecular modeling studies on $\mathbf{4 a}$. Docked pose of $(3 R, 4 S)-\mathbf{4 a}$ (cyan sticks) (A) and of (3S,4R)-4a (green sticks) (B) in the $h \mathrm{MGL}$ binding site (salmon cartoon). The catalytic triad is represented by orange sticks, while oxyanion hole residues are represented by salmon sticks. Nonpolar hydrogen atoms have been omitted. (C) Tetrahedral complex of $h$ MGL (salmon cartoon) and (3R,4S)-4a (cyan sticks) and $(3 S, 4 R)-\mathbf{4 a}$ (green sticks). H-bonds are indicated by dotted lines in the same colors of the ligands.

$(3 S, 4 R)-4 a$ (Figure 3A,B). (3R,4S)-4a establishes a series of H-bonds with His269, Ala51, Met123, and with the catalytic Ser122, while $(3 S, 4 R)-4 a$ only interacts with Ser122 and Ala51. These differences of interactions are translated into slightly different Glide XP score values $((3 R, 4 S)-4 \mathbf{a}-11.181 \mathrm{kcal} / \mathrm{mol}$, and $(3 S, 4 R)-4 \mathbf{a}-10.608 \mathrm{kcal} / \mathrm{mol})$ and in different estimated free-binding energy values calculated by using Prime MM/GBSA $\left(\Delta G_{\text {bind }}(3 R, 4 S)-4 \mathbf{a}=-119.05 \mathrm{kcal} / \mathrm{mol}\right.$, and $\Delta G_{\text {bind }}(3 S, 4 R)-4 \mathbf{a}$
$=-117.39 \mathrm{kcal} / \mathrm{mol})$. Notably, the key interactions with His269, Ala51, and Met123, the two latter residues being constituents of the oxyanion hole, are relevant for MGL inhibition. ${ }^{9}$ Our computational analysis also highlights the peculiar interactions of both enantiomers into the $h$ MGL binding site, with the catalytic residues (Ser122 and His 269 for $(3 R, 4 S)-4 a$ and only Ser 122 for $(3 S, 4 R)-4 a)$ and with the oxyanion hole residues (Ala51 and Met123 for $(3 R, 4 S)-\mathbf{4 a}$ and only Ala51 for $(3 S, 4 R)-\mathbf{4 a})$.

Proteomic analysis proved the formation of a carbamoylated adduct of the enzyme with $\mathbf{4 a}$. This data suggests the formation of an initial tetrahedral intermediate which was also probed, in silico, by a covalent docking approach. A tetrahedral complex generated by using GOLD software ${ }^{23}$ for $(3 R, 4 S)-4 a$ and (3S,4R)-4a in complex with $h \mathrm{MGL}$ (Figure 3C) highlighted that the binding mode found from classical docking studies (Figure $3 \mathrm{~A}-\mathrm{C})$ is maintained and $(3 R, 4 S)-\mathbf{4 a}$ and $(3 S, 4 R)-\mathbf{4 a}$ similarly establish a H-bond with Gly50 (oxyanion hole residue), deeply positioned into the binding site. Consequently, we can assume that stereoselectivity of the interaction of $\mathbf{4 a}$ enantiomers with $h \mathrm{MGL}$ can rely on the different enantiomer/enzyme reciprocal recognition at the early stage of interactions, as explained by the docking studies (Figures 3A,B).

$h$ FAAH/hMGL selectivity ratio (Table 1$)$ for $(3 R, 4 S)$ - and $(3 S, 4 R)-4 a$ was explained by docking studies on the $h$ FAAH enzyme. $(3 R, 4 S)-4 \mathbf{a}$ and $(3 S, 4 R)-4 \mathbf{a}$ are not able to completely reach the active site of the enzyme (Figures $4 A, B$ ), as they do not lie in a favorable position into $h F A A H$ active site but are accommodated in a pocket located in the upper part of the catalytic site. The XP-scoring function explains the micromolar affinity for $h$ FAAH (4a Glide score values: -6.804 and $-6.452 \mathrm{kcal} / \mathrm{mol}$ for $(3 R, 4 S)$ - and (3S,4R)-4a respectively).

Affinity-Based Proteomic Profiling (ABPP) Assay. Compound 4a was found to potently inhibit MGL with an $\mathrm{IC}_{50}$ of $\sim 10 \mathrm{nM}$ in a competitive ABPP assay carried out in the rat brain proteome and did not exhibit cross-reactivity with other rat brain serine hydrolase off-targets up to $500 \mathrm{nM}$, including FAAH, ABHD6, and ABHD12 (Figure 5A). Only at concentrations $\geq 500 \mathrm{nM}$ some inhibition of lysophopholipase A1/2 was observed (Figure 5B).

Preliminary in Vitro ADME+T Profiling. Besides its in vitro profile, additional features that contribute to designate $\mathbf{4 a}$ as an excellent MGL inhibitor are the lack of mutagenic effect in the Salmonella typhimurium strains TA98 and TA100 at any of the concentrations tested (following the assay conditions of the Ames' test, Figure 6) along with its experimentally determined physicochemical features. 4a showed a favorable solubility and a chemical stability profile at both neutral and acidic $\mathrm{pH}$ (Supporting Information, Figure S7A). Metabolic stability to $h$ CYP3A4 and parallel artificial membrane permeability assay confirmed the stability and high permeability through artificial membranes of $\mathbf{4 a}$ (Supporting Information, Figures S7B,C).

Brain penetration, evaluated by using a human in vitro bloodbrain barrier model, is high $\left(P_{\text {app }}=47 \times 10^{-6} \mathrm{~cm} / \mathrm{s} \pm 6.81\right)$, showing that 4 a may easily cross the human blood-brain barrier. Notably, the measured $P_{\text {app }}$ for Lucifer yellow, the nonpermeant molecule used as marker of endothelium integrity and coincubated with $100 \mu \mathrm{M} 4 \mathrm{a}$ (see Experimental Section for details), is low $\left(P_{\mathrm{app}}=9.48 \times 10^{-6} \mathrm{~cm} / \mathrm{s} \pm 1.68\right)$ and is in the same range found when Lucifer yellow is administered alone. This data indicates that transport of $\mathbf{4 a}$ across the blood-brain barrier is not due to any toxic effect on the endothelium.

Cardiovascular adverse effects heavily contribute to drug withdrawals from the market and represent one of the major 


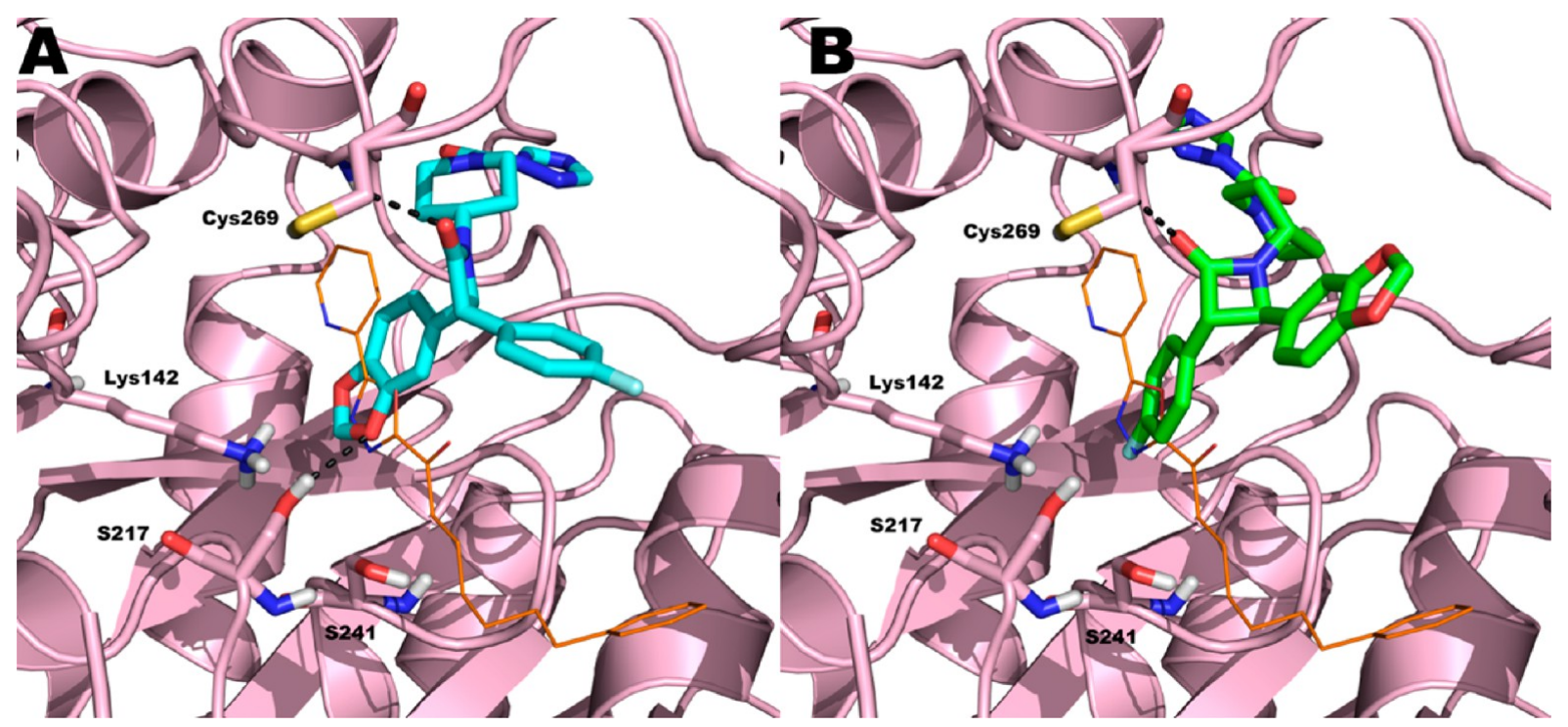

Figure 4. XP-Glide predicted binding mode into $h$ FAAH (pink cartoon) binding site of (3R,4S)-4a (cyan sticks) (A) and of (3S,4R)-4a (green sticks) (B). Catalytic triad (Ser241-Ser217-Lys142) is indicated by sticks, and the H-bonds are represented by black dotted line. Moreover, the crystallized ligand was superposed to the docking complex, and it is represented by orange lines in order to highlight the impossibility of both enantiomers of $4 \mathbf{a}$ to reach the catalytic Ser241 of $h$ FAAH. In fact, $(3 R, 4 S)-4 a(A)$ is able to interact with one of the residues belonging to the catalytic triad (Ser217), but no interactions with the catalytic Ser241 are observed. For $(3 S, 4 R)-4 a(B)$, no contacts with the catalytic triad are observed.

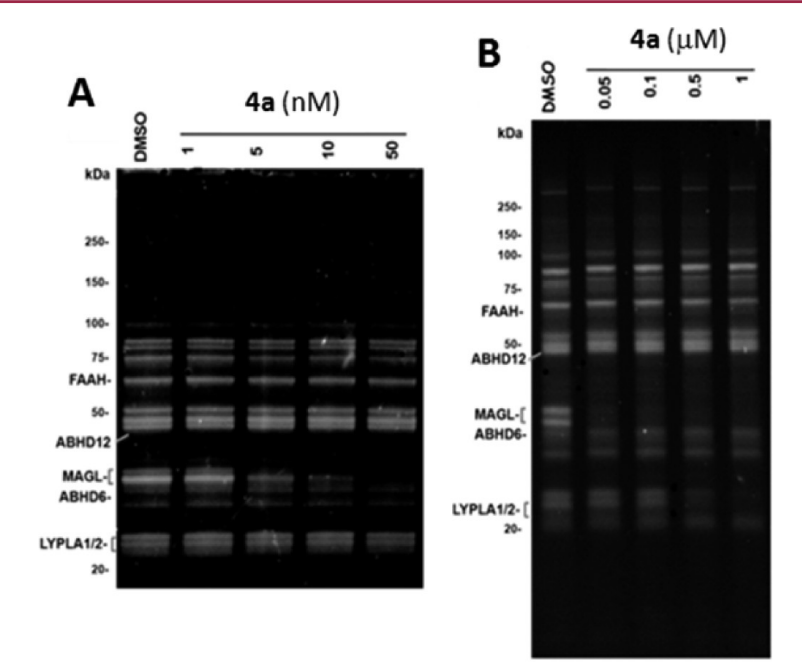

Figure 5. In vitro competitive ABPP of $4 a$ using the serine hydrolasedirected probe $\mathrm{FP}-\mathrm{Rh}$ in the membrane fraction of the rat brain proteome. (A) 4a potently and selectively inhibits FP-Rh labeling of MGL, with lysophopholipase Al/2 (LYPLAl/2) being the only detectable off-target (B) (from $500 \mathrm{nM}$ to $1 \mu \mathrm{M}$ of $4 \mathrm{a}$ ).

hurdles in the development of new drugs. To evaluate the potential cardiovascular toxicity of compound $4 a$, its effect on cardiac mechanical function and electrocardiogram (ECG) in Langendorff-isolated rat hearts was assessed, as previously described. ${ }^{24}$ Under control conditions, left ventricle pressure (LVP) and coronary perfusion pressure (CPP) values of $60.07 \pm$ 8.96 and $57.45 \pm 2.58 \mathrm{mmHg}(n=4)$, respectively, were obtained. At the maximum concentration tested $(1 \mu \mathrm{M})$, 4a significantly increased CPP to $75.19 \pm 7.80 \mathrm{mmHg}(n=4, * * P<0.01$, repeated measures ANOVA and Dunnett's post test). Moreover, 4a, up to $1 \mu \mathrm{M}$, did not affect surface ECG (Table 3).

At the maximum concentration tested, $4 \mathbf{a}$ increases coronary perfusion pressure leaving unaltered heart contractility and ECG, thus allowing us to exclude cardiac toxicity for this compound.
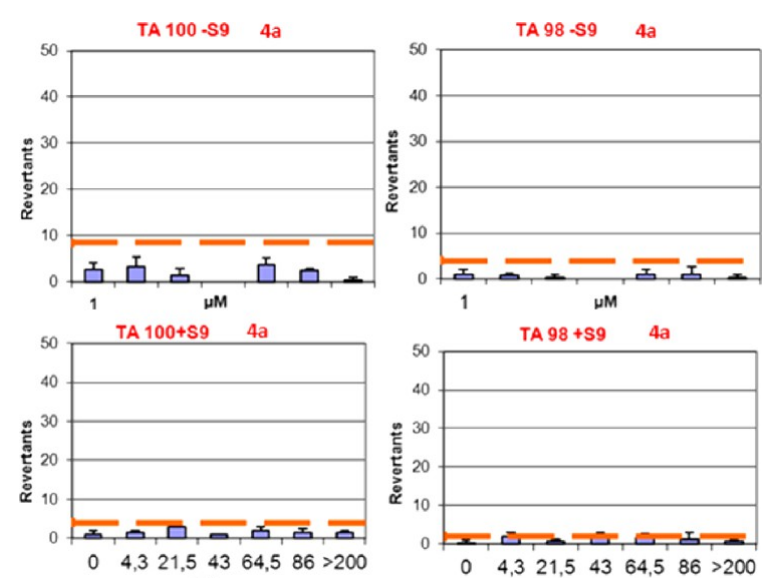

$\mu \mathrm{M}$

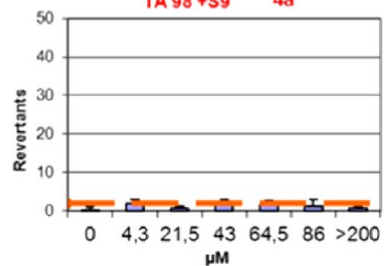

Figure 6. Ames test performed on S. typhimurium TA98 and TA100 strains for compound $\mathbf{4 a}$.

In Vivo Efficacy of Compound 4a. Efficacy of $4 a$ on the Experimental Autoimmune Encephalomyelitis (EAE) Model of $M S$ in Rodents. Although no single animal model exists recapitulating all the features of MS, EAE is considered an animal model suitable for studying it ${ }^{25}$ because it shares some important features with human MS, such as the chronic course and histopathological evidence of demyelination and neuroinflammation. ${ }^{26}$ We therefore evaluated $\mathbf{4 a}$ in the myelin glycoprotein 35-55 ( $\left.\mathrm{MOG}_{35-55}\right)$-induced EAE rodent model (the disease was induced as detailed in the Experimental Section). Drug prophylactic treatment $(4 \mathrm{a}, 3 \mathrm{mg} / \mathrm{kg}$, ip) started at the asymptomatic stage of disease at day 6 postimmunization (dpi), up to the acute stage of the disease $(21 \pm 0.1 \mathrm{dpi}$, when the maximal score gravity is observed). Administration of 4a clearly influenced the disease progression, as assessed by the significant lower daily clinical score observed in 4a-administered EAE mice when compared to vehicletreated EAE mice starting from $8 \mathrm{dpi}$, as well as by the dramatic change in the cumulative score level (Figure 7). Interestingly, we found that the reduction of the daily clinical score induced by 
Table 3. Effects of 4a on HR, RR, PQ QRS, QT, QTc in Langendorff Perfused Rat Hearts ${ }^{a}$

$\begin{array}{lcccccc}4 \mathrm{a}(\mu \mathrm{M}) & \text { HR }(\mathrm{BPM}) & \mathrm{RR}(\mathrm{ms}) & \text { PQ }(\mathrm{ms}) & \text { QRS }(\mathrm{ms}) & \text { QT }(\mathrm{ms}) \\ \text { none } & 252.78 \pm 9.28 & 238.38 \pm 9.23 & 45.62 \pm 4.49 & 14.26 \pm 0.71 & 75.65 \pm 0.87 & 155.26 \pm 2.96 \\ 0.001 & 254.38 \pm 9.83 & 236.93 \pm 9.51 & 46.03 \pm 4.81 & 14.02 \pm 0.71 & 76.38 \pm 1.14 \\ 0.01 & 254.18 \pm 8.35 & 236.80 \pm 7.85 & 46.46 \pm 5.25 & 13.50 \pm 0.29 & 76.17 \pm 0.48 \\ 0.1 & 252.65 \pm 7.66 & 238.15 \pm 7.23 & 46.18 \pm 5.84 & 13.75 \pm 0.48 & 15.13 \pm 2.45 \\ 1 & 255.50 \pm 7.36 & 235.48 \pm 6.90 & 46.67 \pm 5.23 & 13.75 \pm 0.47 & 76.02 \pm 1.84\end{array}$

${ }^{a}$ Each value represents mean \pm SEM $(n=4)$. HR, frequency; RR, cycle length; PQ atrioventricular conduction time; QRS, intraventricular conduction time; QT, duration of ventricular depolarization and repolarization, i.e., the action potential duration; QTc, corrected QT.
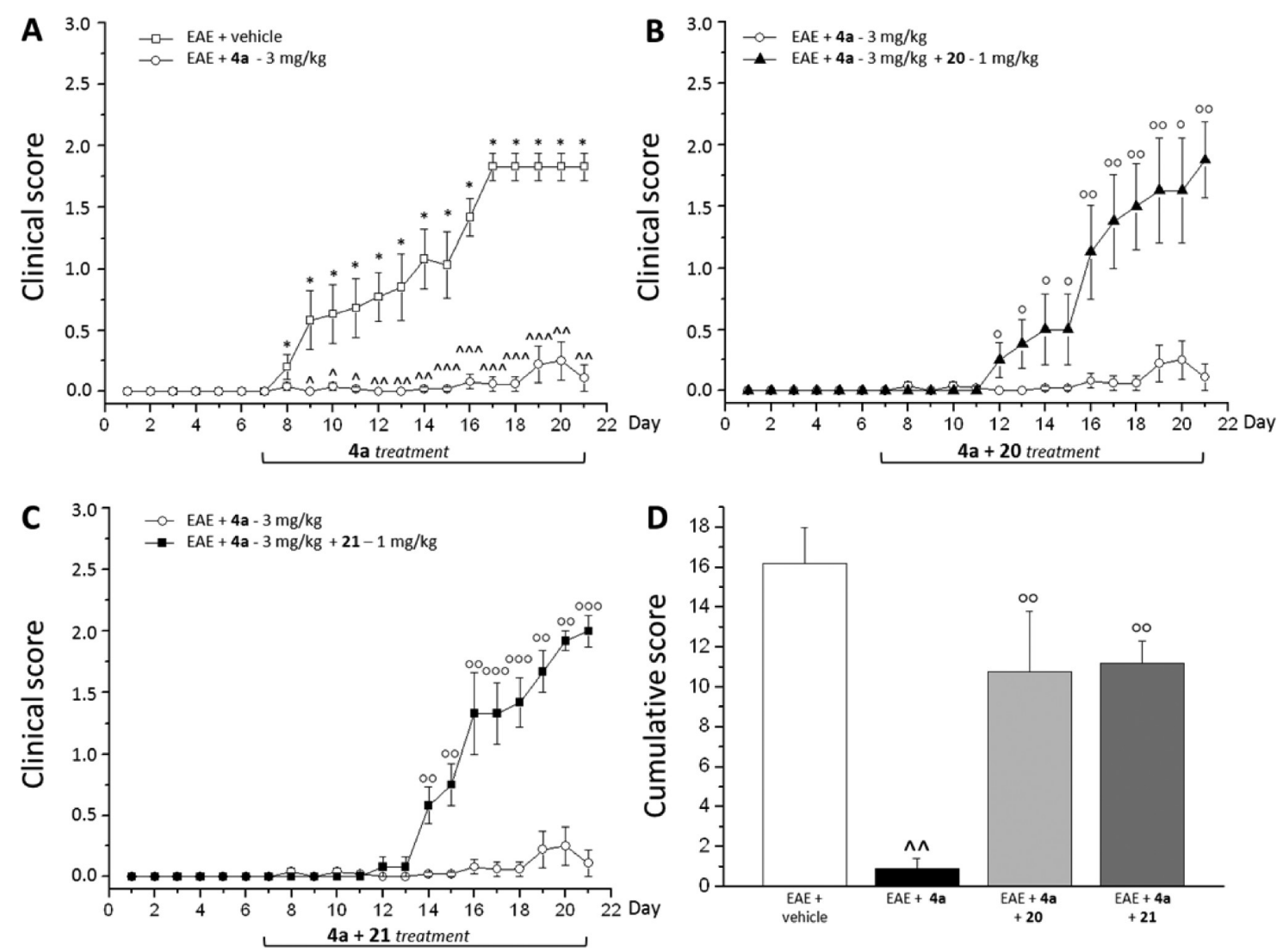

Figure 7. In vivo effects of compound 4a on EAE mice. Female C57BL/6J mice were immunized with the MOG $35-55$ peptide and were randomly assigned to the following group: untreated EAE mice, $4 \mathrm{a}(3 \mathrm{mg} / \mathrm{kg}$ ip $)$ treated EAE mice; $\mathbf{4 a}(3 \mathrm{mg} / \mathrm{kg}$ ip $) / 20(1 \mathrm{mg} / \mathrm{kg})$-treated EAE mice; $4 \mathrm{a}(3 \mathrm{mg} / \mathrm{kg}$ ip) $/ 21(1 \mathrm{mg} / \mathrm{kg})$ treated EAE mice. Mice were administered drugs daily. 20 and 21 were administered $10 \mathrm{~min}$ before 4a. Clinical score is expressed as average (media \pm SEM) daily score $(A-C)$ or as cumulative score $(D)$. Data are means \pm SEM from untreated EAE mice (A, white square, 7 animals), from $4 \mathrm{a}(3 \mathrm{mg} / \mathrm{kg}$ ip) treated EAE mice (A-C white circle, 9 animals); from $\mathbf{4 a}(3 \mathrm{mg} / \mathrm{kg}$ ip) $/ \mathbf{2 0}(1 \mathrm{mg} / \mathrm{kg})$ treated EAE mice (B, black triangle, 4 animals); from $4 \mathrm{a}(3 \mathrm{mg} / \mathrm{kg}$ ip $) / 21(1 \mathrm{mg} / \mathrm{kg})$ treated EAE mice $(\mathrm{C}$, black square, 6 animals $) .{ }^{*} P<0.05$ vs EAE + vehicle $1 \mathrm{dpi} ;{ }^{\wedge} P<0.05$ vs EAE + vehicle in the same day; ${ }^{\wedge} P<0.01$ vs EAE + vehicle in the same day; ${ }^{\wedge \wedge} P<0.001$ vs EAE + vehicle.

prophylactic 4a could involve the modulation of the endocannabinoid system. Actually, administration (starting from 6 dpi for 14 days) of the selective $\mathrm{CB} 1$ antagonist/inverse agonist $N$-(piperidin-1-yl)-5-(4-iodophenyl)-1-(2,4-dichlorophenyl)-4methyl-1H-pyrazole-3-carboxamide $20(\mathrm{AM} 251)^{27}$ and the CB2 antagonist/inverse agonist 6-iodo-2-methyl-1-[2-(4-morpholinyl)ethyl]-1H-indol-3-yl] (4-methoxyphenyl)methanone 21 (AM630), ${ }^{28}$ each used at $1 \mathrm{mg} / \mathrm{kg}$, ip, both prevented the protecting effect of $\mathbf{4 a}$ starting at $12 \mathrm{dpi}$. Although activation of both $\mathrm{CB} 1$ and $\mathrm{CB} 2$ receptors by endogenous $2-\mathrm{AG}$ could be beneficial for the course of the disease, ${ }^{2}$ we found that the blockade of each one of the two receptors significantly reduced the positive effects exerted by $\mathbf{4 a}$, leading us to conclude that in $\mathbf{4 a - t r e a t e d ~ E A E ~ m i c e ~ b o t h ~}$ receptors did not compensate but synergize with each other mediating the $4 \mathbf{a}$-induced amelioration of the clinical score. The respective contribution of $\mathrm{CB} 1$ and $\mathrm{CB} 2$ in ameliorating the course of the demyelinating disorder in EAE mice chronically administered 4a deserves further investigation to be clarified.

Changes in spontaneous locomotor activity were not observed in $\mathbf{4 a - a d m i n i s t e r e d ~ c o n t r o l ~ ( n o n i m m u n i z e d ) ~ m i c e ~ w h e n ~ c o m p a r e d ~}$ to control (not shown).

Following these encouraging results, we performed histological evaluation of myelin using the Luxol Fast Blue staining (Figure 8). Pallor of Luxol Fast Blue stain is associated with a reduction in the density of staining for myelin. Representative images of spinal cord of each experimental group are shown in Figure 8. In the spinal cord white matter of the control group, a normal structural organization of myelin is evident. By contrast, in EAE mice demyelinated areas are present (arrows). The EAE mice treated with $\mathbf{4 a}$ exhibited myelin-density staining that was 

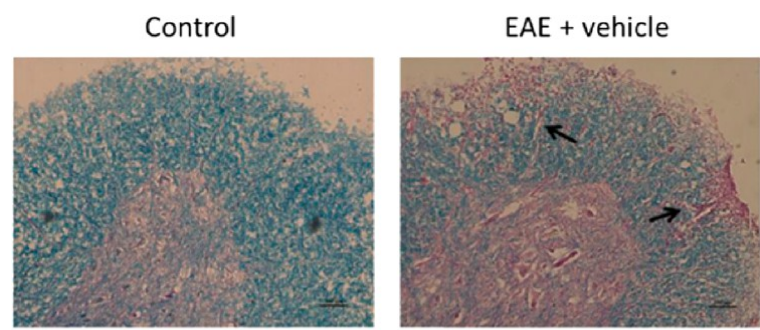

$\mathrm{EAE}+4 \mathrm{a}$

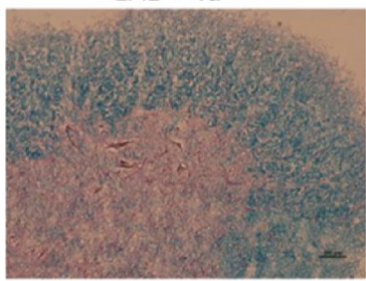

$E A E+4 a+20$
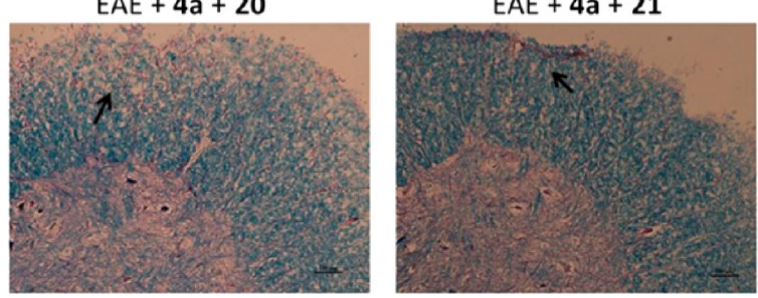

Figure 8. Myelin in the white matter of mice spinal cord. Luxol Fast Blue staining shows areas of intact myelin (blue) and demyelination (pink). Arrows indicate the demyelinated areas in EAE, EAE $+\mathbf{4 a}+\mathbf{2 0}$ and $\mathrm{EAE}+\mathbf{4 a}+\mathbf{2 1}$ groups. Scale bar: $100 \mu \mathrm{m}$.

comparable to that of control animals. Treatment with 4 a plus 20 or $\mathbf{2 1}$ revealed the presence of some demyelinated areas in comparison to control animals and to 4a-treated groups, but these areas were less extended than in EAE group (Figure 8).

In Figure 9A, a panel of representative microglia staining in the spinal cord is shown. Cells were stained with Ibal antibody. Immunofluorescence staining for microglia revealed an increase of Ibal-positive cells/optic field in the white matter anterior fasciculus of EAE mice $(247.66 \pm 11.50)$. The results of the quantitative measurements of microglia density are shown in Figure 9B. 4a administration in EAE mice caused a reduction in the number of Ibal positive cells in the area evaluated that was, at least in part, reverted by coadministration of 20 or 21 (Figure 9A,B).

Antinociceptive Effects of $\mathbf{4 a}$ in Animal Models of Inflammatory and Neuropathic Pain. The in vivo antinociceptive profile of $\mathbf{4 a}$ was also evaluated in two different animal models of pain. The compound inhibited both the first and second phase of the nocifensive response to formalin in mice (model of acute inflammatory pain). The maximum effect was reached at the dose of $0.3 \mathrm{mg} / \mathrm{kg}$ (ip) (Figure 10A). MGL inhibition may also produce therapeutic actions by impeding the conversion of 2-AG into arachidonic acid and hence prostaglandins, thus acting in an endocannabinoid- and CBR-independent manner. ${ }^{29}$ However, we found that the effect of $4 a$ in the formalin test was mediated by both $\mathrm{CB} 1$ and $\mathrm{CB} 2$ receptors because both the selective CB1 antagonist/inverse agonist 20 and the CB2 antagonist/inverse agonist 21 (each used at $1 \mathrm{mg} / \mathrm{kg}$, ip), administered $10 \mathrm{~min}$ prior to $4 \mathrm{a}$, antagonized the antinociceptive actions of the compound (Figure 10B). Importantly, 5 min after the administration of $4 \mathrm{a}(0.3 \mathrm{mg} / \mathrm{kg}$, ip $)$, the levels of $2-\mathrm{AG}$ in the spinal cord and paw skin of mice coadministered with formalin, measured by LC-MS, were found to be elevated (Table 4, see

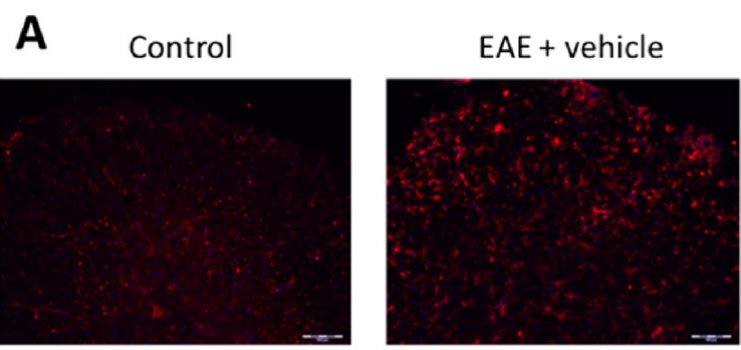

$\mathrm{EAE}+4 \mathrm{a}$

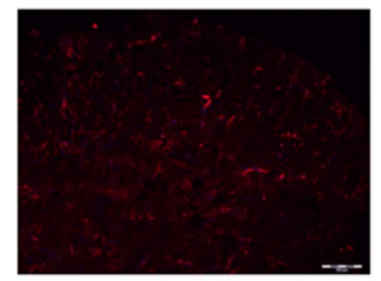

$E A E+4 a+20$

$E A E+4 a+21$
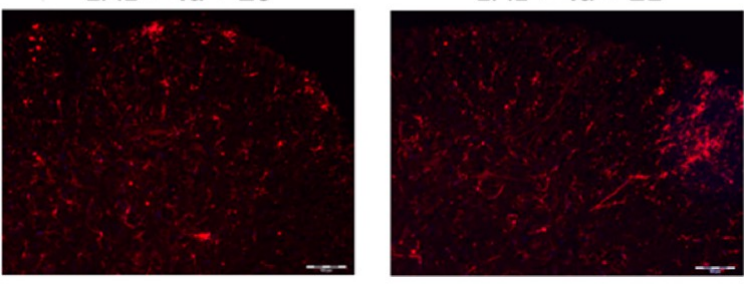

B

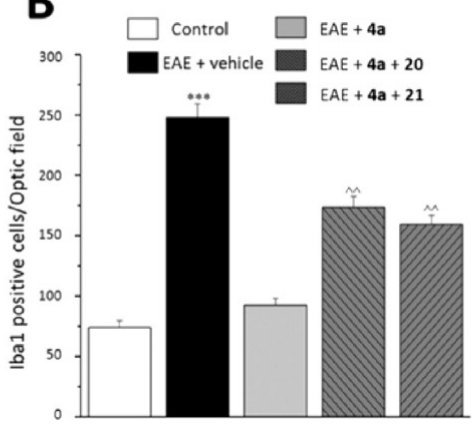

Figure 9. Microglia positive cells in the white matter of mice spinal cord. (A) Representative images of microglia cells stained with IBAl (red) and cell nuclei stained with DAPI (blue) in mice white matter of each experimental group are shown. Scale bar: $100 \mu \mathrm{m}$. (B) Quantitative measurements of the number of Ibal positive cells in the white matter spinal cord (anterior fasciculus). Statistical analysis. One-Way ANOVA followed by Bonferroni comparison test: $* * * P<0.001$ vs control and $\mathrm{EAE}+4 \mathrm{a} ;{ }^{\wedge \wedge} P<0.01$ vs control, $\mathrm{EAE}+$ vehicle and $\mathrm{EAE}+4 \mathrm{a}$.

Experimental Procedures for details). These results suggest that compound $\mathbf{4 a}$ alleviates the pain behavior in the formalin test by elevating endogenous 2-AG levels (Table 4), thus indirectly activating both $\mathrm{CB} 1$ and $\mathrm{CB} 2$ receptors, as previously reported for other MGL inhibitors. ${ }^{10}$

Next we evaluated the effect of $4 \mathbf{a}$ in a mouse model of nociceptive behavior caused by the chemotherapeutic agent, oxaliplatin (OXP, Figures 7C,D) ${ }^{30}$ (model of neuropathic pain which is also a common symptom in MS patients). After oral administration, the inhibitor dose-dependently reversed the lowering of the threshold to cold stimuli (cold plate test) induced by OXP, after acute administration on day 14 of OXP treatment, when changes in pain thresholds were fully established (Figure 10C). As shown in Figure 10D, 4a maintained its efficacy after repeated treatments following a preventive protocol (daily oral administration with OXP). Moreover, when subchronically 

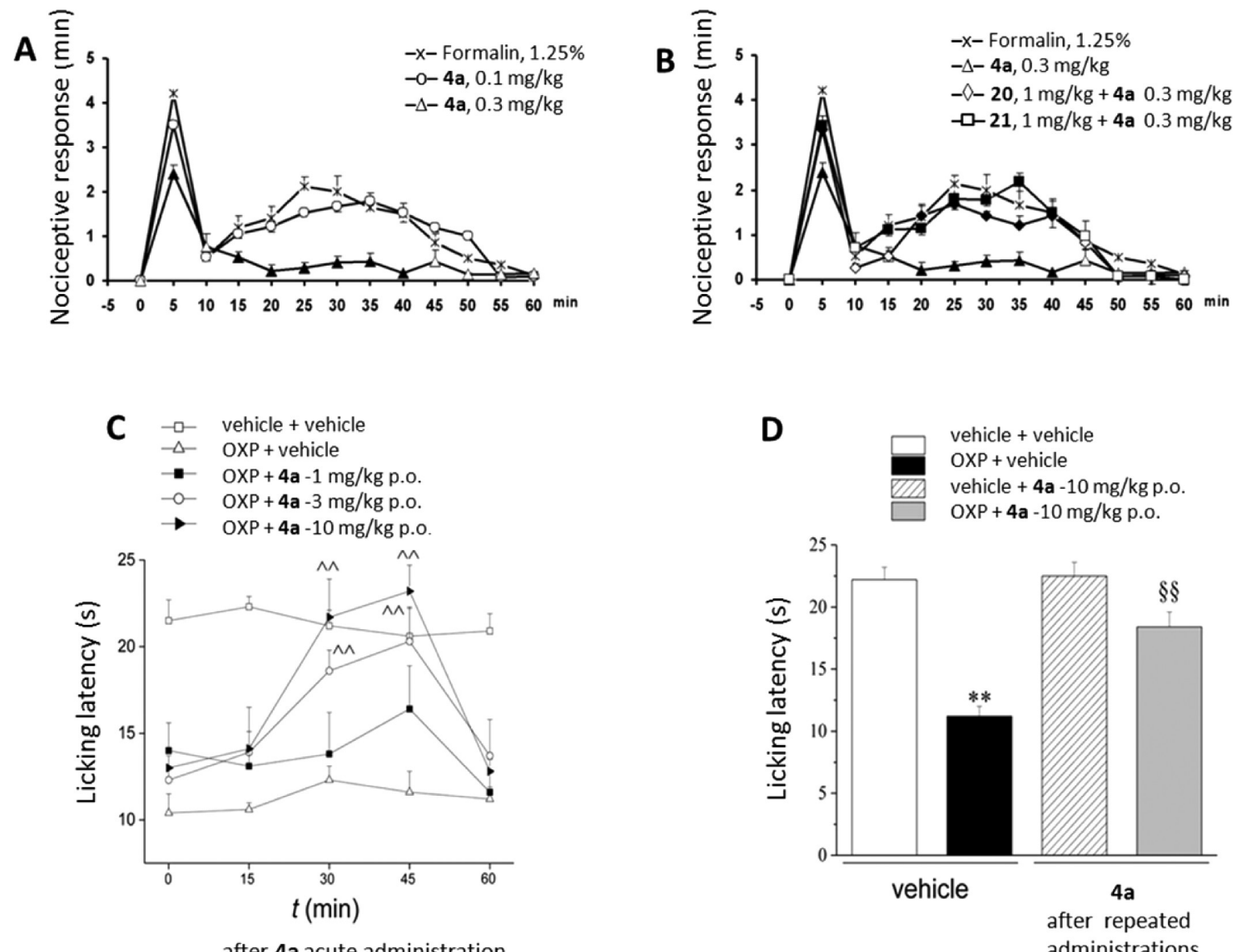

after $\mathbf{4 a}$ acute administration

administrations

Figure 10. In vivo antinociceptive effects of compound 4a. (A,B) Effect of compound $4 a$ on formalin-induced acute pain in mice. The total time of the nociceptive response was measured every $5 \mathrm{~min}$ and expressed in min (see Supporting Information). Data are means \pm SEM from six mice and were analyzed by one-way ANOVA followed by the Newman-Keuls's post hoc test. (A) Effect of $4 \mathbf{a}$ administered ip 10 min before the injection of formalin $(1.25 \%$ in saline, $30 \mu \mathrm{L})$. Filled symbols denote statistically significant differences vs formalin $(P<0.05)$. In $(B)$ the selective $C B 1$ inverse agonist 20 or the CB2 inverse agonist 21 were injected ip 10 min before $4 a$. (C,D) Effect of $4 a$ on OXP-induced neuropathic pain. On day 14 of OXP administration $(2.4 \mathrm{mg} / \mathrm{kg}$ ip daily), the response to a thermal stimulus was evaluated by the cold plate test measuring the latency to pain-related behavior (lifting or licking of the paw). (C) Acute effect of $\mathbf{4 a}$ was evaluated after a single po administration (time 0) over time. (D) Subchronic effect of $4 \mathbf{a}$ was observed on day 14 after repeated administrations (daily starting from the first day of OXP treatment), and the measurement was performed $24 \mathrm{~h}$ after the last administration. $\hat{A} P<0.01$ respect to the value before treatment $(0)$; ${ }^{*} P<0.01$ in comparison to vehicle + vehicle; ${ }^{\S \S} P<0.01$ in comparison to OXP + vehicle. Each value is the mean of 12 mice.

Table 4. 2-AG Tissue Levels in Formalin Treated Mice Administered (ip) with $4 a$

\begin{tabular}{lcccr} 
& \multicolumn{4}{c}{ 2-AG $(\mathrm{pmol} / \mathrm{g})^{a}$} \\
\cline { 2 - 5 } & vehicle/saline & $\mathbf{4 a} /$ saline & vehicle/formalin & $\mathbf{4 a} /$ formalin \\
spinal cord & $6.4 \pm 0.4$ & $9.7 \pm 1.3$ & $3.8 \pm 0.4$ & $6.6 \pm 0.7^{b}$ \\
paw skin & $6.1 \pm 0.3$ & $11.0 \pm 2.8$ & $10.8 \pm 1.5$ & $14.1 \pm 1.6^{b}$
\end{tabular}

${ }^{a}$ Means \pm SEM, $n=4$, analyzed by ANOVA + Bonferroni's posthoc test. ${ }^{b} P<0.05$ vs vehicle/formalin.

administered, $4 \mathrm{a}$ was efficacious $24 \mathrm{~h}$ after the last administration. These antinociceptive properties of $\mathbf{4 a}$ are related to conditions of hypersensitivity, such as neuropathic pain, because 4 a did not modify normal pain thresholds evaluated in the hot-plate test (Supporting Information, Table S1).

Collectively, the in vivo results are well consistent with the theory that the endocannabinoid signalosome ${ }^{31}$ may play a role in the modulation of the symptoms of $\mathrm{MS}^{32}$ as well as in the molecular events underlying nociception, thus pointing to selective inhibition of MGL as a potential strategy to produce beneficial effects against the clinical outcomes of MS.

\section{CONCLUSIONS}

Combining bioinformatics and molecular modeling efforts we generated an updated 3D pharmacophore model for the development of selective hMGL inhibitors. Synthetic accessibility, high potency and selectivity, and an interesting preliminary pharmacokinetic profile, including low geno/cardio-toxicity, characterize the novel $\beta$-lactam inhibitor 4a. We proved a stereoselective inhibition of MGL with the $(3 R, 4 S)$-4a enantiomer (Figure 3), being 70 times and 8 times more potent than 1 and its distomer, respectively, against the human enzyme (4a $\mathrm{IC}_{50}$ $h \mathrm{MGL}=4 \mathrm{nM}$ vs $\left.1 \mathrm{IC}_{50} h \mathrm{MGL}=285 \mathrm{nM}\right)$ (Table 1$)$. The mechanism of action (specific interaction with the catalytic Ser122) was assessed by top-down and bottom-up proteomics experiments while the high selectivity was assessed in binding experiments on CBRs and on a proteome-based assay of hydrolases including FAAH and ABHD (Figure 5). 4a lacks mutagenic effect in the $S$. typhimurium strains TA98 and TA100 (Figure 6) and cardiotoxicity as assessed by ECG measurements in Langendorff-isolated rat hearts. Additionally, 4a showed favorable solubility, chemical stability at both neutral and acidic $\mathrm{pH}$, metabolic stability to $h \mathrm{CYP} 3 \mathrm{~A} 4$ and high permeability 
through artificial membranes, and high brain penetration. Antinociceptive effects on inflammatory and neuropathic pain animal models were assessed after oral and ip administration of $4 a$. After ip administration of $0.3 \mathrm{mg} / \mathrm{kg}$, a marked analgesic action was registered, with inhibition of both the first and second phase of the nocifensive response to formalin. Oral administration of $4 a$ already at $1 \mathrm{mg} / \mathrm{kg}$ dose dependently reversed the lowering of the threshold to cold stimuli (cold plate test) induced by OXP, indicating its efficacy in the treatment of neuropathic pain. In vivo experiments evidenced a clear-cut dependence of the pain reliever profile of $\mathbf{4 a}$ from endocannabinoid system activation (Figure 7). 4a was also tested on the EAE animal model (ip administration, Figure 8), 4a elicited a striking beneficial effect on disease progression that could involve both CB1- and CB2-mediated signaling. Interestingly, in animals administered with either CBR antagonists/inverse agonists (20 and 21), the seriousness of the clinical symptoms was delayed when compared to control EAE mice, reaching however a maximum clinical score (at $21 \mathrm{dpi}$ ) that was comparable to that detected in untreated EAE mice (at $17 \mathrm{dpi}$ ). In line with these data, in EAE mice treated with $\mathbf{4 a}$, the histological evaluation of myelin, by Luxol Fast Blue staining, demonstrated a significant reduction of the demyelinated areas which was partially counteracted by the coadministration of $\mathbf{2 0}$ and $\mathbf{2 1}$ (Figure 8). Notably these outcomes were paralleled by those obtained when looking at microglia because $4 a$ decreased the number of Ibal positive cells, an effect that is in part prevented by coadministration of $\mathbf{2 0}$ or $\mathbf{2 1}$ (Figure 9). Because EAE is a disease model widely applied to study MS, these data could suggest MGL inhibition as an innovative therapeutic approach for treating MS symptoms.

\section{EXPERIMENTAL SECTION}

Chemistry. Unless otherwise specified, materials were purchased from commercial suppliers and used without further purification. Reaction progress was monitored by TLC using silica gel 60 F254 $(0.040-0.063 \mathrm{~mm})$ with detection by UV. Silica gel $60(0.040-$ $0.063 \mathrm{~mm})$ or aluminum oxide $90(0.063-0.200 \mathrm{~mm})$ were used for column chromatography. ${ }^{1} \mathrm{H}$ NMR and ${ }^{13} \mathrm{C}$ NMR spectra were recorded on a Varian $300 \mathrm{MHz}$ spectrometer by using the residual signal of the deuterated solvent as internal standard. Splitting patterns are described as singlet $(\mathrm{s})$, doublet $(\mathrm{d})$, triplet $(\mathrm{t})$, quartet $(\mathrm{q})$, quintet $(\mathrm{p})$, and broad (br); the value of chemical shifts $(\delta)$ are given in ppm and coupling constants $(J)$ in hertz $(\mathrm{Hz})$. ESI-MS spectra were performed by an Agilent 1100 series LC/MSD spectrometer. Melting points were determined in Pyrex capillary tubes using an Electrothermal 8103 apparatus and are uncorrected. Optical rotation values were measured at room temperature using a PerkinElmer model 343 polarimeter operating at $=589 \mathrm{~nm}$, corresponding to the sodium D line. Yields refer to purified products and are not optimized. All moisture-sensitive reactions were performed under argon atmosphere using oven-dried glassware and anhydrous solvents. ESI-MS spectra for exact mass determination were performed on a LTQ Orbitrap Thermo Fischer Scientific instrument. All final compounds were purified by flash column chromatography, and the purity of all compounds tested was $\geq 95 \%$ as determined by elemental analysis. Elemental analyses were performed in a PerkinElmer $240 \mathrm{C}$ elemental analyzer, and the results were within $\pm 0.4 \%$ of the theoretical values unless otherwise noted.

Experimental Procedures. trans-(1- $(1-(1 \mathrm{H}-1,2,4-T r i a z o l e-1-$ carbonyl)piperidin-4-yl)-4-benzo[d][1,3]dioxol-5-yl)-3-(4fluorophenyl)azetidin-2-one (( \pm$)-4 a)$. To a solution of $1 H-1,2,4$-triazole $(15 \mathrm{mg}, 0.22 \mathrm{mmol})$ in dry dichloromethane $(10.0 \mathrm{~mL})$, phosgene $20 \%$ solution in toluene $(115 \mu \mathrm{L}, 0.22 \mathrm{mmol})$ and DMAP $(55 \mathrm{mg}, 0.44 \mathrm{mmol})$ were added and the mixture was stirred at $25^{\circ} \mathrm{C}$ for $1 \mathrm{~h}$. Then a solution of amine $( \pm)-6 \mathrm{a}(40 \mathrm{mg}, 0.11 \mathrm{mmol})$ in dry dichloromethane $(5.0 \mathrm{~mL})$ was added and the reaction was stirred at $25{ }^{\circ} \mathrm{C}$ for $12 \mathrm{~h}$. The solvent was removed under reduced pressure. The crude was purified by means of chromatography on silica gel (1:1 ethyl acetate/n-hexane) to afford compound ( \pm )-4a (30 mg, 60\% yield) as a white solid. ${ }^{1} \mathrm{H}$ NMR $\left(300 \mathrm{MHz}, \mathrm{CDCl}_{3}\right) \delta 8.75(\mathrm{~s}, 1 \mathrm{H}), 7.97(\mathrm{~s}, 1 \mathrm{H}), 7.20(\mathrm{~m}, 2 \mathrm{H}), 7.03(\mathrm{t}, J=$ $8.6 \mathrm{~Hz}, 2 \mathrm{H}), 6.87(\mathrm{~s}, J=7.8 \mathrm{~Hz}, 1 \mathrm{H}), 6.82(\mathrm{~d}, J=0.7 \mathrm{~Hz}, 2 \mathrm{H}), 6.01(\mathrm{~d}, J=$ $1.4 \mathrm{~Hz}, 2 \mathrm{H}), 4.50(\mathrm{~m}, 2 \mathrm{H}), 4.38(\mathrm{~d}, J=2.3 \mathrm{~Hz}, 1 \mathrm{H}), 4.08(\mathrm{~d}, J=2.1 \mathrm{~Hz}$, $1 \mathrm{H}), 3.78(\mathrm{~m}, 1 \mathrm{H}), 3.13(\mathrm{~m}, 2 \mathrm{H}), 2.07(\mathrm{~m}, 2 \mathrm{H}), 1.89(\mathrm{dd}, J=13.4,3.2 \mathrm{~Hz}$, $1 \mathrm{H}), 1.63(\mathrm{qd}, J=11.5,4.1 \mathrm{~Hz}, 2 \mathrm{H}) \cdot{ }^{13} \mathrm{C}$ NMR $\left(75 \mathrm{MHz}, \mathrm{CDCl}_{3}\right) \delta$ $168.4,162.5\left(\mathrm{~d}, J_{\mathrm{C}-\mathrm{F}}=246.6 \mathrm{~Hz}\right), 152.3,148.9,148.6,148.5,146.9$, 132.0, $130.8\left(\mathrm{~d}, J_{\mathrm{C}-\mathrm{F}}=3.3 \mathrm{~Hz}\right), 129.1\left(\mathrm{~d}, J_{\mathrm{C}-\mathrm{F}}=8.1 \mathrm{~Hz}\right), 120.6,116.1$ $\left(\mathrm{d}, J_{\mathrm{C}-\mathrm{F}}=21.6 \mathrm{~Hz}\right), 108.9,106.2,101.7,64.0,63.4,50.7,45.5(2 \mathrm{C}), 30.4$, 30.1. ESI-MS $m / z: 464[\mathrm{M}+\mathrm{H}]^{+}, 486[\mathrm{M}+\mathrm{Na}]^{+}$. HRMS (ESI) $\mathrm{m} / z$ $[\mathrm{M}+\mathrm{H}]^{+}$calcd for $\mathrm{C}_{24} \mathrm{H}_{22} \mathrm{FN}_{5} \mathrm{O}_{4}$ 464.1729, found 464.1731, $[\mathrm{M}+\mathrm{Na}]^{+}$; calcd for $\mathrm{C}_{24} \mathrm{H}_{22} \mathrm{FN}_{5} \mathrm{O}_{4} 486.1548$, found 486.1551; $[\mathrm{M}+\mathrm{K}]^{+}$calcd for $\mathrm{C}_{24} \mathrm{H}_{22} \mathrm{FN}_{5} \mathrm{O}_{4}$ 502.1287, found 502.1289 (100). Anal. $\left(\mathrm{C}_{24} \mathrm{H}_{22} \mathrm{FN}_{5} \mathrm{O}_{4}\right) \mathrm{C}$, $\mathrm{H}, \mathrm{N}$.

(3R,4S)-1-(1-(1H-1,2,4-Triazole-1-carbonyl)piperidin-4-yl)-4benzo[d][1,3]dioxol-5-yl)-3-(4-fluorophenyl)azetidin-2-one ((3R,4S)$(+)-4 a) .{ }^{1} \mathrm{H}$ NMR and ${ }^{13} \mathrm{C}$ NMR are identical to those reported for $( \pm)-4 a$.

(3S,4R)-1-(1-(1H-1,2,4-Triazole-1-carbonyl)piperidin-4-yl)-4benzo[d][1,3]dioxol-5-yl)-3-(4-fluorophenyl)azetidin-2-one ((3S,4R)$(-)-4 a) .{ }^{1} \mathrm{H}$ NMR and ${ }^{13} \mathrm{C}$ NMR are identical to those reported for $( \pm)-4 a$.

4-Nitrophenyl-4-((trans-2-(benzo[d][1,3]dioxol-5-yl)-3-(4-fluorophenyl)-4-oxoazetidin-1-yl)piperidine-1-carboxylate (4b). To a stirred solution of $( \pm)-6 \mathrm{a}(40 \mathrm{mg}, 0.11 \mathrm{mmol})$ in dry dichloromethane $(15.0 \mathrm{~mL})$, 4-nitrophenyl chloroformate $(33 \mathrm{mg}, 0.17 \mathrm{mmol})$ and TEA ( $45 \mu \mathrm{L}, 0.33 \mathrm{mmol}$ ) were added and the mixture was stirred at $25{ }^{\circ} \mathrm{C}$ under $\mathrm{Ar}$ atmosphere for $12 \mathrm{~h}$. The solvent was removed under reduced pressure. The crude was purified by means of chromatography on silica gel ( $1: 4$ ethyl acetate $/ n$-hexane) to afford title compound (30 mg, $52 \%$ yield) as an amorphous white solid. ${ }^{1} \mathrm{H} \mathrm{NMR}\left(300 \mathrm{MHz}, \mathrm{CDCl}_{3}\right) \delta 8.24$ $(\mathrm{d}, J=8.9 \mathrm{~Hz}, 2 \mathrm{H}), 7.42-7.15(\mathrm{~m}, 4 \mathrm{H}), 7.05(\mathrm{t}, J=8.5 \mathrm{~Hz}, 2 \mathrm{H}), 6.90(\mathrm{~s}$, $1 \mathrm{H}), 6.84(\mathrm{~s}, 2 \mathrm{H}), 6.03(\mathrm{~s}, 2 \mathrm{H}), 4.40(\mathrm{br} \mathrm{s}, 1 \mathrm{H}), 4.37-4.02(\mathrm{~m}, 3 \mathrm{H}), 3.71$ $(\mathrm{m}, 1 \mathrm{H}), 3.24-2.79(\mathrm{~m}, 2 \mathrm{H}), 2.23-1.74(\mathrm{~m}, 3 \mathrm{H}), 1.57(\mathrm{~m}, 1 \mathrm{H}) .{ }^{13} \mathrm{C}$ NMR $\left(75 \mathrm{MHz}, \mathrm{CDCl}_{3}\right) \delta 168.4,162.5\left(\mathrm{~d}, J_{\mathrm{C}-\mathrm{F}}=246.6 \mathrm{~Hz}\right), 156.3$, $152.3,148.9,148.6,145.1,132.2,130.9\left(\mathrm{~d}, J_{\mathrm{C}-\mathrm{F}}=3.0 \mathrm{~Hz}\right), 129.1(\mathrm{~d}$, $\left.J_{\mathrm{C}-\mathrm{F}}=8.1 \mathrm{~Hz}\right), 125.3,122.5,120.7,116.2\left(\mathrm{~d}, J_{\mathrm{C}-\mathrm{F}}=21.6 \mathrm{~Hz}\right), 109.0$, $106.3,101.8,63.9,63.5,50.8,43.8$ (2C), 30.2 (2C). ESI-MS $m / z: 534$ $[\mathrm{M}+\mathrm{H}]^{+}$. Anal. $\left(\mathrm{C}_{28} \mathrm{H}_{24} \mathrm{FN}_{3} \mathrm{O}_{7}\right) \mathrm{C}, \mathrm{H}, \mathrm{N}$.

trans-1-(1-(1H-Imidazole-1-carbonyl)piperidin-4-yl)-4-(benzo[d][1,3]dioxol-5-yl)-3-(4-fluorophenyl)azetidin-2-one (4c). To a solution of $( \pm)-6 \mathrm{a}(40 \mathrm{mg}, 0.11 \mathrm{mmol})$ in dry dichloromethane $(15.0 \mathrm{~mL}), 1,1-$ carbonyldiimidazole $(35 \mathrm{mg}, 0.22 \mathrm{mmol}$ ) was added and the mixture was stirred at $25{ }^{\circ} \mathrm{C}$ for $12 \mathrm{~h}$. The solvent was removed under reduced pressure. The crude was purified by means of chromatography on silica gel (1:1 ethyl acetate $/ n$-hexane) to afford title compound $(20 \mathrm{mg}, 40 \%$ yield) as an amorphous white solid. ${ }^{1} \mathrm{H}$ NMR $\left(300 \mathrm{MHz}, \mathrm{CDCl}_{3}\right) \delta 7.82$ (s, 1H), $7.21(\mathrm{~m}, 2 \mathrm{H}), 7.15(\mathrm{~s}, 1 \mathrm{H}), 7.06(\mathrm{~m}, 3 \mathrm{H}), 6.88(\mathrm{~d}, J=1.0 \mathrm{~Hz}$, $1 \mathrm{H}), 6.83(\mathrm{~d}, J=1.2 \mathrm{~Hz}, 2 \mathrm{H}), 6.03(\mathrm{~s}, 2 \mathrm{H}), 4.38(\mathrm{~d}, J=2.2 \mathrm{~Hz}, 1 \mathrm{H}), 4.09$ $(\mathrm{m}, 3 \mathrm{H}), 3.73(\mathrm{~m}, 1 \mathrm{H}), 3.23-3.01(\mathrm{~m}, 2 \mathrm{H}), 2.07(\mathrm{~m}, 2 \mathrm{H}), 1.89(\mathrm{~m}, 1 \mathrm{H})$, $1.59(\mathrm{~m}, 1 \mathrm{H}) .{ }^{13} \mathrm{C} \mathrm{NMR}\left(75 \mathrm{MHz}, \mathrm{CDCl}_{3}\right) \delta 168.4,162.5\left(\mathrm{~d}, J_{\mathrm{C}-\mathrm{F}}=\right.$ $246.7 \mathrm{~Hz}), 151.0,149.0,148.6,137.1,131.9,130.7\left(\mathrm{~d}, J_{\mathrm{C}-\mathrm{F}}=3.2 \mathrm{~Hz}\right)$, $129.9,129.0\left(\mathrm{~d}, J_{\mathrm{C}-\mathrm{F}}=8.1 \mathrm{~Hz}\right), 120.6,118.2,116.2\left(\mathrm{~d}, J_{\mathrm{C}-\mathrm{F}}=21.5 \mathrm{~Hz}\right)$, $109.0,106.2,101.8,63.9,63.5,50.6,45.6,45.4,30.4,30.1$. ESI-MS $m / z$ : $463[\mathrm{M}+\mathrm{H}]^{+}, 485[\mathrm{M}+\mathrm{Na}]^{+}$. Anal. $\left(\mathrm{C}_{25} \mathrm{H}_{23} \mathrm{FN}_{4} \mathrm{O}_{4}\right) \mathrm{C}, \mathrm{H}, \mathrm{N}$.

1,1,1,3,3,3-Hexafluoropropan-2-yl-4-(2-(benzo[d][1,3]dioxol-5yl)-3-(4-fluorophenyl)-4-oxoazetidin-1-yl)piperidine-1-carboxylate (4d). To a stirred solution of 1,1,1,3,3,3-hexafluoroisopropanol (13 mg, $0.08 \mathrm{mmol})$ in dry dichloromethane $(5.0 \mathrm{~mL})$, triphosgene $(12 \mathrm{mg}$, $0.04 \mathrm{mmol})$ and DIPEA $(30 \mu \mathrm{L}, 0.16 \mathrm{mmol})$ were added and the mixture was stirred at $\mathrm{rt}$ under $\mathrm{Ar}$ atmosphere for $30 \mathrm{~min}$. Then, a solution of $( \pm)-6 \mathrm{a}(25 \mathrm{mg}, 0.07 \mathrm{mmol})$ in dry dichloromethane $(2.5 \mathrm{~mL})$ was added and the mixture was stirred at $\mathrm{rt}$ for $12 \mathrm{~h}$. The solvent was removed under reduced pressure, and the crude was purified by means of flash chromatography (1:2 ethyl acetate/ $n$-hexane) to afford title compound (11 mg, 30\% yield) as colorless oil. ${ }^{1} \mathrm{H}$ NMR $\left(300 \mathrm{MHz}, \mathrm{CDCl}_{3}\right) \delta 7.22(\mathrm{~m}, 2 \mathrm{H}), 7.04(\mathrm{~m}, 2 \mathrm{H}), 6.87(\mathrm{~d}, J=1.0 \mathrm{~Hz}$, $1 \mathrm{H}), 6.82(\mathrm{~d}, J=1.1 \mathrm{~Hz}, 2 \mathrm{H}), 6.02(\mathrm{~s}, 2 \mathrm{H}), 5.70(\mathrm{p}, J=6.2 \mathrm{~Hz}, 1 \mathrm{H}), 4.36$ $(\mathrm{d}, J=2.3 \mathrm{~Hz}, 1 \mathrm{H}), 4.26-3.90(\mathrm{~m}, 3 \mathrm{H}), 3.66(\mathrm{~m}, 1 \mathrm{H}), 2.92(\mathrm{~m}, 2 \mathrm{H})$, $2.14-1.98(\mathrm{~m}, 1 \mathrm{H}), 1.93(\mathrm{~m}, 2 \mathrm{H}), 1.51(\mathrm{~m}, 1 \mathrm{H}) .{ }^{13} \mathrm{C} \mathrm{NMR}(75 \mathrm{MHz}$, 
$\left.\mathrm{CDCl}_{3}\right) \delta 168.3,162.50\left(\mathrm{~d}, J_{\mathrm{C}-\mathrm{F}}=246.8 \mathrm{~Hz}\right), 151.5,148.9,148.6,132.0$, $130.8\left(\mathrm{~d}, J_{\mathrm{C}-\mathrm{F}}=3.3 \mathrm{~Hz}\right), 129.0\left(\mathrm{~d}, J_{\mathrm{C}-\mathrm{F}}=8.1 \mathrm{~Hz}\right), 120.8\left(\mathrm{~d}, J_{\mathrm{C}-\mathrm{F}}=\right.$ $283.3 \mathrm{~Hz}), 120.6,116.2\left(\mathrm{~d}, J_{\mathrm{C}-\mathrm{F}}=21.6 \mathrm{~Hz}\right), 108.9,106.2,101.7,68.4$, $63.9,63.43,50.5,44.0,43.4,30.0(2 \mathrm{C})$. ESI-MS $m / z: 563[\mathrm{M}+\mathrm{H}]^{+}, 585$ $[\mathrm{M}+\mathrm{Na}]^{+}$. Anal. $\left(\mathrm{C}_{25} \mathrm{H}_{21} \mathrm{~F}_{7} \mathrm{~N}_{2} \mathrm{O}_{5}\right) \mathrm{C}, \mathrm{H}, \mathrm{N}$.

trans-1-(1-(1H-1,2,4-Triazole-1-carbonyl)piperidin-4-yl)-4(benzo[d][1,3]dioxol-5-yl)-3-(4-methoxyphenyl)azetidin-2-one (4e). Title compound was obtained starting from $\mathbf{6 b}$ as described for compound $( \pm)-\mathbf{4 a}$. The crude was purified by means of chromatography on silica gel (1:1 ethyl acetate/ $n$-hexane) to afford pure title compound (30 mg, 57\% yield) as an amorphous white solid. ${ }^{1} \mathrm{H}$ NMR $(300 \mathrm{MHz}$, $\left.\mathrm{CDCl}_{3}\right) \delta 8.76(\mathrm{~s}, 1 \mathrm{H}), 7.98(\mathrm{~s}, 1 \mathrm{H}), 7.15(\mathrm{~d}, J=7.1 \mathrm{~Hz}, 2 \mathrm{H}), 6.90(\mathrm{~m}$, $3 \mathrm{H}), 6.82(\mathrm{~s}, 2 \mathrm{H}), 6.02(\mathrm{~s}, 2 \mathrm{H}), 4.70-4.27(\mathrm{~m}, 3 \mathrm{H}), 4.05(\mathrm{br} \mathrm{s}, 1 \mathrm{H}), 3.79$ $(\mathrm{m}, 4 \mathrm{H}), 3.15(\mathrm{~m}, 2 \mathrm{H}), 2.09(\mathrm{~m}, 2 \mathrm{H}), 1.90(\mathrm{~d}, J=12.3 \mathrm{~Hz}, 1 \mathrm{H}), 1.66(\mathrm{~m}$, 1H). ${ }^{13} \mathrm{C}$ NMR (75 MHz, $\left.\mathrm{CDCl}_{3}\right) \delta 169.1,159.4,152.4,148.8,148.7$, 148.4, 132.4, 128.6, 127.1, 120.6, 114.6, 108.9, 106.3, 101.7, 64.3, 63.7, 55.6, 50.6, 45.4, 30.4, 30.2. ESI-MS $m / z: 476[\mathrm{M}+\mathrm{H}]^{+}, 498[\mathrm{M}+\mathrm{Na}]^{+}$. Anal. $\left(\mathrm{C}_{25} \mathrm{H}_{25} \mathrm{~N}_{5} \mathrm{O}_{5}\right) \mathrm{C}, \mathrm{H}, \mathrm{N}$.

trans-1-(1-(1H-1,2,4-Triazole-1-carbonyl)piperidin-4-yl)-4-(3,4-dimethoxyphenyl)-3-(4-methoxyphenyl)azetidin-2-one (4f). Title compound was obtained starting from $6 c$ as described for compound $( \pm)-4 a$. The crude was purified by means of chromatography on silica gel (1:1 ethyl acetate $/ n$-hexane) to afford title compound $(25 \mathrm{mg}, 52 \%$ yield $)$ as an amorphous white solid. ${ }^{1} \mathrm{H}$ NMR $\left(300 \mathrm{MHz}, \mathrm{CDCl}_{3}\right) \delta 8.74(\mathrm{~s}, 1 \mathrm{H})$, $7.96(\mathrm{~s}, 1 \mathrm{H}), 7.16(\mathrm{~d}, J=8.3 \mathrm{~Hz}, 2 \mathrm{H}), 6.97-6.78(\mathrm{~m}, 5 \mathrm{H}), 4.70-4.29$ (m, 3H), 4.09 (br s, $1 \mathrm{H}), 3.89(\mathrm{~s}, 6 \mathrm{H}), 3.84-3.72(\mathrm{~m}, 4 \mathrm{H}), 3.13(\mathrm{~m}$, $2 \mathrm{H}), 2.11(\mathrm{~m}, 2 \mathrm{H}), 1.87(\mathrm{dd}, J=13.3,3.0 \mathrm{~Hz}, 1 \mathrm{H}), 1.62(\mathrm{qd}, J=12.0$, $4.0 \mathrm{~Hz}, 1 \mathrm{H}) .{ }^{13} \mathrm{C} \mathrm{NMR}\left(75 \mathrm{MHz}, \mathrm{CDCl}_{3}\right) \delta 169.3,159.4,152.3,149.9$, 149.8, 148.6, 146.9, 130.9, 128.6, 127.2, 119.4, 114.7, 111.6, 109.0, 64.2, 63.8, 56.3, 56.2, 55.6, 50.6, 45.4, 30.4, 30.2. ESI-MS $m / z: 492[\mathrm{M}+\mathrm{H}]^{+}$, $514[\mathrm{M}+\mathrm{Na}]^{+}$. Anal. $\left(\mathrm{C}_{26} \mathrm{H}_{29} \mathrm{~N}_{5} \mathrm{O}_{5}\right) \mathrm{C}, \mathrm{H}, \mathrm{N}$.

trans-1-(1-(1H-1,2,4-Triazole-1-carbonyl)piperidin-4-yl)-3,4-bis(3,4-dimethoxyphenyl)azetidin-2-one (4g). Title compound was obtained starting from $\mathbf{6 d}$ as described for compound ( \pm )-4a. The crude was purified by means of chromatography on silica gel (1:1 ethyl acetate $/ n$-hexane) to afford title compound ( $20 \mathrm{mg}, 45 \%$ yield) as an amorphous white solid. ${ }^{1} \mathrm{H}$ NMR $\left(300 \mathrm{MHz}, \mathrm{CDCl}_{3}\right) \delta 8.76(\mathrm{~s}, 1 \mathrm{H})$, $7.98(\mathrm{~s}, 1 \mathrm{H}), 7.03-6.79(\mathrm{~m}, 5 \mathrm{H}), 6.75(\mathrm{~s}, 1 \mathrm{H}), 4.71-4.33(\mathrm{~m}, 3 \mathrm{H}), 4.11$ $(\mathrm{d}, J=1.7 \mathrm{~Hz}, 1 \mathrm{H}), 3.99-3.73(\mathrm{~m}, 13 \mathrm{H}), 3.15(\mathrm{~m}, 2 \mathrm{H}), 2.11(\mathrm{~m}, 2 \mathrm{H})$, $1.88(\mathrm{~m}, 1 \mathrm{H}), 1.66(\mathrm{~m}, 1 \mathrm{H}) .{ }^{13} \mathrm{C} \mathrm{NMR}\left(75 \mathrm{MHz}, \mathrm{CDCl}_{3}\right) \delta 169.1,152.3$, $150.0,149.8,149.5,148.9,148.7,130.9,127.6,119.5,111.0,111.7,110.8$, $108.9,64.5,63.8,56.3,56.2,56.2,50.6,45.3,30.4,30.2$. ESI-MS $m / z: 522$ $[\mathrm{M}+\mathrm{H}]^{+}, 544[\mathrm{M}+\mathrm{Na}]^{+}$. Anal. $\left(\mathrm{C}_{27} \mathrm{H}_{31} \mathrm{~N}_{5} \mathrm{O}_{6}\right) \mathrm{C}, \mathrm{H}, \mathrm{N}$.

trans-1-(1-(1H-1,2,4-Triazole-1-carbonyl)piperidin-4-yl)-3,4-bis(4methoxyphenyl)azetidin-2-one (4h). Title compound was obtained starting from $\mathbf{6 d}$ as described for compound $( \pm)-\mathbf{4 a}$. The crude was purified by means of chromatography on silica gel (1:1 ethyl acetate/ $n$-hexane) to afford title compound ( $24 \mathrm{mg}, 47 \%$ yield) as an amorphous white solid. ${ }^{1} \mathrm{H}$ NMR $\left(300 \mathrm{MHz}, \mathrm{CDCl}_{3}\right) \delta 8.74(\mathrm{~s}, 1 \mathrm{H}), 7.97(\mathrm{~s}, 1 \mathrm{H})$, $7.30(\mathrm{~m}, 2 \mathrm{H}), 7.15(\mathrm{~d}, J=8.7 \mathrm{~Hz}, 2 \mathrm{H}), 6.99-6.78(\mathrm{~m}, 4 \mathrm{H}), 4.76-4.30$ $(\mathrm{m}, 3 \mathrm{H}), 4.07(\mathrm{~d}, J=2.1 \mathrm{~Hz}, 1 \mathrm{H}), 3.83-3.67(\mathrm{~m}, 7 \mathrm{H}), 3.1(\mathrm{~m}, 2 \mathrm{H}), 2.09$ $(\mathrm{m}, 2 \mathrm{H}), 1.85(\mathrm{dd}, J=13.2,3.5 \mathrm{~Hz}, 1 \mathrm{H}), 1.61(\mathrm{~m}, 1 \mathrm{H}) .{ }^{13} \mathrm{C}$ NMR $\left(75 \mathrm{MHz}, \mathrm{CDCl}_{3}\right) \delta 169.2,160.3,159.4,152.2,148.6,146.9,130.4$, 128.6, 127.9, 127.2, 114.8, 114.6, 64.3, 63.4, 55.6, 55.5, 50.5, 45.5, 30.4, 30.2. ESI-MS $m / z: 462[\mathrm{M}+\mathrm{H}]^{+}, 484[\mathrm{M}+\mathrm{Na}]^{+}$. Anal. $\left(\mathrm{C}_{25} \mathrm{H}_{27} \mathrm{~N}_{5} \mathrm{O}_{4}\right)$ $\mathrm{C}, \mathrm{H}, \mathrm{N}$.

trans-4-(Benzo[d][1,3]dioxol-5-yl)-1-(1-benzylpiperidin-4-yl)-3-(4fluorophenyl)azetidin-2-one (( \pm )-5a). A solution of 4-fluorophenylacetic acid $(385 \mathrm{mg}, 2.49 \mathrm{mmol})$ and triphosgene $(245 \mathrm{mg}, 0.83 \mathrm{mmol})$ in dry dichloromethane $(15.0 \mathrm{~mL})$ was heated at $50^{\circ} \mathrm{C}$ for $30 \mathrm{~min}$. Then a solution of imine $11 \mathrm{a}(1.66 \mathrm{mmol})$ in dry dichloromethane $(5.0 \mathrm{~mL})$ was added dropwise, followed by the addition of TEA $(695 \mu \mathrm{L}$, $4.98 \mathrm{mmol}$ ), and the mixture was heated at $50{ }^{\circ} \mathrm{C}$ for $12 \mathrm{~h}$. The solvent was removed under reduced pressure. The crude was purified by means of flash chromatography on silica gel (1:2 ethyl acetate/ $n$-hexane) to afford compound $\mathbf{5 a}\left(460 \mathrm{mg}, 61 \%\right.$ yield) as a pale-yellow oil. ${ }^{1} \mathrm{H}$ NMR $\left(300 \mathrm{MHz}, \mathrm{CDCl}_{3}\right) \delta 7.24(\mathrm{~m}, 7 \mathrm{H}), 7.02(\mathrm{t}, J=8.6 \mathrm{~Hz}, 2 \mathrm{H}), 6.89$ $(\mathrm{s}, 1 \mathrm{H}), 6.81(\mathrm{~m}, 2 \mathrm{H}), 5.98(\mathrm{~s}, 2 \mathrm{H}), 4.37(\mathrm{~d}, J=2.2 \mathrm{~Hz}, 1 \mathrm{H}), 4.02(\mathrm{~d}, J=$ $1.6 \mathrm{~Hz}, 1 \mathrm{H}), 3.58(\mathrm{~m}, 1 \mathrm{H}), 3.44(\mathrm{~s}, 2 \mathrm{H}), 2.83(\mathrm{dd}, J=34.7,11.2 \mathrm{~Hz}, 2 \mathrm{H})$, $1.98(\mathrm{~m}, 4 \mathrm{H}), 1.71(\mathrm{dd}, J=12.6,2.9 \mathrm{~Hz}, 1 \mathrm{H}), 1.52(\mathrm{qd}, J=11.9,3.9 \mathrm{~Hz}$,
$1 \mathrm{H}) .{ }^{13} \mathrm{C} \mathrm{NMR}\left(75 \mathrm{MHz}, \mathrm{CDCl}_{3}\right) \delta 168.4,162.6\left(\mathrm{~d}, J_{\mathrm{C}-\mathrm{F}}=246.3 \mathrm{~Hz}\right)$, $148.7,148.3,138.4,132.9,131.3\left(\mathrm{~d}, J_{\mathrm{C}-\mathrm{F}}=3.2 \mathrm{~Hz}\right), 129.3,129.2(\mathrm{~d}$, $\left.J_{\mathrm{C}-\mathrm{F}}=8.1 \mathrm{~Hz}\right), 128.4,127.3,120.5,116.1\left(\mathrm{~d}, J_{\mathrm{C}-\mathrm{F}}=21.5 \mathrm{~Hz}\right), 108.8$, 106.4, 101.6, 63.9, 63.3, 63.2, 52.6, 52.40, 51.3, 30.7, 30.4. ESI-MS $m / z$ : $459[\mathrm{M}+\mathrm{H}]^{+}, 481[\mathrm{M}+\mathrm{Na}]^{+}$. Anal. $\left(\mathrm{C}_{28} \mathrm{H}_{27} \mathrm{FN}_{2} \mathrm{O}_{3}\right) \mathrm{C}, \mathrm{H}, \mathrm{N}$.

trans-4-(Benzo[d][1,3]dioxol-5-yl)-1-(1-benzylpiperidin-4-yl)-3-(4methoxyphenyl)azetidin-2-one (5b). Starting from 4-methoxylphenylacetic acid $(415 \mathrm{mg}, 2.49 \mathrm{mmol})$ and imine $11 \mathrm{a}(1.66 \mathrm{mmol})$, the title compound was obtained following the same procedure reported for $( \pm)-5 a$. The crude was purified by means of flash chromatography on silica gel ( $1: 2$ ethyl acetate $/ n$-hexane) to afford title compound ( $500 \mathrm{mg}$, $64 \%$ yield $)$ as a pale-yellow oil. ${ }^{1} \mathrm{H}$ NMR $\left(300 \mathrm{MHz}, \mathrm{CDCl}_{3}\right) \delta 7.26(\mathrm{~m}$, $5 \mathrm{H}), 7.16(\mathrm{~m}, 2 \mathrm{H}), 6.88(\mathrm{~m}, 3 \mathrm{H}), 6.80(\mathrm{~m}, 2 \mathrm{H}), 5.99(\mathrm{~s}, 2 \mathrm{H}), 4.36(\mathrm{~d}, J=$ $2.2 \mathrm{~Hz}, 1 \mathrm{H}), 3.97(\mathrm{~d}, J=2.1 \mathrm{~Hz}, 1 \mathrm{H}), 3.77(\mathrm{~s}, 3 \mathrm{H}), 3.59(\mathrm{~m}, 1 \mathrm{H}), 3.44(\mathrm{~s}$, $2 \mathrm{H}), 2.83(\mathrm{~m}, 2 \mathrm{H}), 2.01(\mathrm{~m}, 4 \mathrm{H}), 1.70(\mathrm{dd}, J=12.7,2.8 \mathrm{~Hz}, 1 \mathrm{H}), 1.52$ (qd, $J=11.6,3.9 \mathrm{~Hz}, 1 \mathrm{H})$. ESI-MS $m / z: 471[\mathrm{M}+\mathrm{H}]^{+}, 493[\mathrm{M}+\mathrm{Na}]^{+}$.

trans-1-(1-Benzylpiperidin-4-yl)-4-(3,4-dimethoxyphenyl)-3-(4methoxyphenyl)azetidin-2-one (5c). Starting from 4-methoxyphenylacetic acid $(415 \mathrm{mg}, 2.49 \mathrm{mmol})$ and imine $11 \mathbf{b}(1.66 \mathrm{mmol})$, the title compound was obtained following the same procedure reported for $( \pm)-5$ a. The crude was purified by means of flash chromatography on silica gel ( $1: 2$ ethyl acetate $/ n$-hexane) to afford title compound ( $440 \mathrm{mg}$, $54 \%$ yield $)$ as a pale-yellow oil. ${ }^{1} \mathrm{H}$ NMR $\left(300 \mathrm{MHz}, \mathrm{CDCl}_{3}\right) \delta 7.24(\mathrm{~m}$, $5 \mathrm{H}), 7.15(\mathrm{~m}, 2 \mathrm{H}), 6.89(\mathrm{~m}, 5 \mathrm{H}), 4.38(\mathrm{~d}, J=2.2 \mathrm{~Hz}, 1 \mathrm{H}), 4.01(\mathrm{~d}, J=$ $2.1 \mathrm{~Hz}, 1 \mathrm{H}), 3.86(\mathrm{~s}, 6 \mathrm{H}), 3.75(\mathrm{~s}, 3 \mathrm{H}), 3.60(\mathrm{~m}, 1 \mathrm{H}), 3.41(\mathrm{~s}, 2 \mathrm{H}), 2.80$ $(\mathrm{dd}, J=36.3,9.4 \mathrm{~Hz}, 2 \mathrm{H}), 1.98(\mathrm{~m}, 4 \mathrm{H}), 1.68(\mathrm{dd}, J=12.3,2.4 \mathrm{~Hz}, 1 \mathrm{H})$, $1.50(\mathrm{qd}, J=11.8,3.7 \mathrm{~Hz}, 1 \mathrm{H})$. ESI-MS $m / z: 487[\mathrm{M}+\mathrm{H}]^{+}, 509$ $[\mathrm{M}+\mathrm{Na}]^{+}$.

trans-1-(1-Benzylpiperidin-4-yl)-3,4-bis(3,4-dimethoxyphenyl)azetidin-2-one (5d). Starting from 3,4-dimethoxyphenylacetic acid $(490 \mathrm{mg}, 2.49 \mathrm{mmol})$ and imine $11 \mathrm{~b}(1.66 \mathrm{mmol})$, the title compound was obtained following the same procedure reported for $( \pm)-5 a$. The crude was purified by means of flash-chromatography on silica gel (1:2 ethyl acetate $/ n$-hexane) to afford title compound ( $385 \mathrm{mg}, 45 \%$ yield) as pale-yellow oil. ${ }^{1} \mathrm{H}$ NMR $\left(300 \mathrm{MHz}, \mathrm{CDCl}_{3}\right) \delta 7.25(\mathrm{~m}, 5 \mathrm{H}), 7.02-6.61$ $(\mathrm{m}, 6 \mathrm{H}), 4.40(\mathrm{~d}, J=2.1 \mathrm{~Hz}, 1 \mathrm{H}), 4.01(\mathrm{~d}, J=2.1 \mathrm{~Hz}, 1 \mathrm{H}), 3.88(\mathrm{~s}, 6 \mathrm{H})$, $3.83(\mathrm{~s}, 6 \mathrm{H}), 3.62(\mathrm{~m}, 1 \mathrm{H}), 3.43(\mathrm{~m}, 2 \mathrm{H}), 2.97(\mathrm{dd}, J=12.6,1.7 \mathrm{~Hz}, 1 \mathrm{H})$, $2.81(\mathrm{dd}, J=37.6,10.3 \mathrm{~Hz}, 1 \mathrm{H}), 1.99(\mathrm{~m}, 4 \mathrm{H}), 1.68(\mathrm{~d}, J=10.6 \mathrm{~Hz}, 1 \mathrm{H})$, $1.50(\mathrm{qd}, J=11.5,2.7 \mathrm{~Hz}, 1 \mathrm{H})$. ESI-MS $m / z: 517[\mathrm{M}+\mathrm{H}]^{+}, 539$ $[\mathrm{M}+\mathrm{Na}]^{+}$.

trans-1-(1-Benzylpiperidin-4-yl)-3,4-bis(4-methoxyphenyl)azetidin-2-one (5e). Starting from 4-methoxyphenylacetic acid $(415 \mathrm{mg}, 2.49 \mathrm{mmol})$ and imine $11 \mathrm{c}(1.66 \mathrm{mmol})$, the title compound was obtained following the same procedure reported for $( \pm)-5 a$. The crude was purified by means of flash-chromatography on silica gel (1:2 ethyl acetate $/ n$-hexane) to afford title compound ( $440 \mathrm{mg}, 59 \%$ yield) as a pale-yellow oil. ${ }^{1} \mathrm{H}$ NMR $\left(300 \mathrm{MHz}, \mathrm{CDCl}_{3}\right) \delta 7.35-7.21(\mathrm{~m}, 7 \mathrm{H})$, $7.13(\mathrm{~m}, 2 \mathrm{H}), 6.88(\mathrm{~m}, 4 \mathrm{H}), 4.39(\mathrm{~d}, J=2.0 \mathrm{~Hz}, 1 \mathrm{H}), 3.99(\mathrm{~d}, J=2.0 \mathrm{~Hz}$, $1 \mathrm{H}), 3.82(\mathrm{~s}, 3 \mathrm{H}), 3.79(\mathrm{~s}, 3 \mathrm{H}), 3.59(\mathrm{~m}, 1 \mathrm{H}), 3.43(\mathrm{~s}, 2 \mathrm{H}), 2.81(\mathrm{~m}$, $2 \mathrm{H}), 2.00(\mathrm{~m}, 4 \mathrm{H}), 1.65(\mathrm{dd}, J=12.6,3.1 \mathrm{~Hz}, 1 \mathrm{H}), 1.45(\mathrm{qd}, J=12.0$, $3.9 \mathrm{~Hz}, 1 \mathrm{H})$. ESI-MS $m / z: 457[\mathrm{M}+\mathrm{H}]^{+}$.

trans-4-(Benzo[d][1,3]dioxol-5-yl)-3-(4-fluorophenyl)-1-(piperidin-4-yl)azetidin-2-one $(( \pm)-6 a)$. To a solution of $( \pm)-5$ a $(100 \mathrm{mg}$, $0.22 \mathrm{mmol})$ in methanol $(25.0 \mathrm{~mL})$, a catalytic amount of Pd/C $10 \%$ was added and the mixture was stirred under hydrogen atmosphere at $1 \mathrm{~atm}$ for $2 \mathrm{~h}$. Then $\mathrm{Pd} / \mathrm{C}$ was filtered off and the solvent was removed under reduced pressure. The crude transparent oil (quantitative yield) was used in the following step without any further purification. ${ }^{1} \mathrm{H}$ NMR $\left(300 \mathrm{MHz}, \mathrm{CD}_{3} \mathrm{OD}\right) \delta 7.30(\mathrm{~m}, 2 \mathrm{H}), 7.11(\mathrm{~m}, 2 \mathrm{H}), 7.01(\mathrm{~s}, 1 \mathrm{H}), 6.96$ $(\mathrm{d}, J=8.0 \mathrm{~Hz}, 1 \mathrm{H}), 6.85(\mathrm{~d}, J=7.9 \mathrm{~Hz}, 1 \mathrm{H}), 5.98(\mathrm{~s}, 2 \mathrm{H}), 4.65(\mathrm{~d}, J=$ $2.1 \mathrm{~Hz}, 1 \mathrm{H}), 4.19(\mathrm{~d}, J=1.8 \mathrm{~Hz}, 1 \mathrm{H}), 3.72(\mathrm{~m}, 1 \mathrm{H}), 3.41(\mathrm{~m}, 2 \mathrm{H}), 3.31$ $(\mathrm{m}, 1 \mathrm{H}), 3.03(\mathrm{~m}, 2 \mathrm{H}), 2.21(\mathrm{~m}, 2 \mathrm{H}), 2.09(\mathrm{dd}, J=14.1,3.5 \mathrm{~Hz}, 1 \mathrm{H})$, $1.87(\mathrm{qd}, J=11.6,4.0 \mathrm{~Hz}, 1 \mathrm{H}) .{ }^{13} \mathrm{C} \mathrm{NMR}\left(75 \mathrm{MHz}, \mathrm{CD}_{3} \mathrm{OD}\right) \delta 169.5$, $162.6\left(\mathrm{~d}, J_{\mathrm{C}-\mathrm{F}}=245.1 \mathrm{~Hz}\right), 148.9,148.6,131.7,131.0\left(\mathrm{~d}, J_{\mathrm{C}-\mathrm{F}}=3.2 \mathrm{~Hz}\right)$, $129.3\left(\mathrm{~d}, J_{\mathrm{C}-\mathrm{F}}=8.2 \mathrm{~Hz}\right), 120.1,115.6\left(\mathrm{~d}, J_{\mathrm{C}-\mathrm{F}}=21.8 \mathrm{~Hz}\right), 108.5,106.4$, 101.7, 63.3, 42.8, 42.7, 27.1, 26.7. ESI-MS $m / z: 369[\mathrm{M}+\mathrm{H}]^{+}$. Anal. $\left(\mathrm{C}_{21} \mathrm{H}_{21} \mathrm{FN}_{2} \mathrm{O}_{3}\right) \mathrm{C}, \mathrm{H}, \mathrm{N}$.

trans-4-(Benzo[d][1,3]dioxol-5-yl)-3-(4-methoxyphenyl)-1-(piperidin-4-yl)azetidin-2-one (6b). Starting from $5 \mathbf{b}(100 \mathrm{mg}, 0.21 \mathrm{mmol})$, title compound was obtained following the same procedure used for 
( \pm )-6a. ${ }^{1} \mathrm{H}$ NMR (300 MHz, $\left.\mathrm{CDCl}_{3}\right) \delta 7.15(\mathrm{~d}, J=8.4 \mathrm{~Hz}, 2 \mathrm{H}), 6.86$ $(\mathrm{m}, 3 \mathrm{H}), 6.78(\mathrm{~m}, 2 \mathrm{H}), 5.99(\mathrm{~s}, 2 \mathrm{H}), 4.37(\mathrm{~d}, J=1.9 \mathrm{~Hz}, 1 \mathrm{H}), 4.00(\mathrm{~d}, J=$ $1.7 \mathrm{~Hz}, 1 \mathrm{H}), 3.79(\mathrm{~s}, 3 \mathrm{H}), 3.67(\mathrm{~m}, 1 \mathrm{H}), 3.05(\mathrm{~m}, 2 \mathrm{H}), 2.58(\mathrm{~m}, 2 \mathrm{H})$, $1.86(\mathrm{~m}, 4 \mathrm{H}), 1.37(\mathrm{qd}, J=12.3,4.2 \mathrm{~Hz}, 1 \mathrm{H})$. ESI-MS $m / z: 381[\mathrm{M}+$ $\mathrm{H}]^{+}$.

trans-4-(3,4-Dimethoxyphenyl)-3-(4-methoxyphenyl)-1-(piperidin-4-yl)azetidin-2-one (6c). Starting from $5 \mathrm{c}(100 \mathrm{mg}, 0.21 \mathrm{mmol})$, title compound was obtained following the same procedure used for (土)-6a. ${ }^{1} \mathrm{H}$ NMR $\left(300 \mathrm{MHz}, \mathrm{CDCl}_{3}\right) \delta 7.15(\mathrm{~d}, J=8.6 \mathrm{~Hz}, 2 \mathrm{H}), 6.87$ $(\mathrm{m}, 5 \mathrm{H}), 4.39(\mathrm{~d}, J=2.2 \mathrm{~Hz}, 1 \mathrm{H}), 4.03(\mathrm{~d}, J=2.0 \mathrm{~Hz}, 1 \mathrm{H}), 3.88(\mathrm{~s}, 6 \mathrm{H})$, $3.77(\mathrm{~s}, 3 \mathrm{H}), 3.67(\mathrm{~m}, 1 \mathrm{H}), 3.03(\mathrm{~m}, 2 \mathrm{H}), 2.56(\mathrm{~m}, 2 \mathrm{H}), 1.83(\mathrm{~m}, 4 \mathrm{H})$, 1.35 (qd, $J=12.1,4.1 \mathrm{~Hz}, 1 \mathrm{H})$. ESI-MS $m / z: 397[\mathrm{M}+\mathrm{H}]^{+}$.

trans-3,4-Bis(3,4-dimethoxyphenyl)-1-(piperidin-4-yl)azetidin-2one $(6 d)$. Starting from $5 \mathrm{~d}(100 \mathrm{mg}, 0.19 \mathrm{mmol})$, title compound was obtained following the same procedure used for $( \pm)-6 \mathrm{a} .{ }^{1} \mathrm{H}$ NMR $\left(300 \mathrm{MHz}, \mathrm{CDCl}_{3}\right) \delta 7.06-6.62(\mathrm{~m}, 6 \mathrm{H}), 4.41(\mathrm{~d}, J=2.3 \mathrm{~Hz}, 1 \mathrm{H}), 4.04$ $(\mathrm{d}, J=1.9 \mathrm{~Hz}, 1 \mathrm{H}), 3.89(\mathrm{~s}, 3 \mathrm{H}), 3.88(\mathrm{~s}, 3 \mathrm{H}), 3.86(\mathrm{~s}, 3 \mathrm{H}), 3.85(\mathrm{~s}, 3 \mathrm{H})$, $3.68(\mathrm{~m}, 1 \mathrm{H}), 2.97(\mathrm{~m}, 2 \mathrm{H}), 2.58(\mathrm{~m}, 2 \mathrm{H}), 1.87(\mathrm{~m}, 4 \mathrm{H}), 1.39(\mathrm{~m}, 1 \mathrm{H})$. ESI-MS $m / z: 427[\mathrm{M}+\mathrm{H}]^{+}$.

trans-3,4-Bis(4-methoxyphenyl)-1-(piperidin-4-yl)azetidin-2-one (6e). Starting from 5e $(100 \mathrm{mg}, 0.22 \mathrm{mmol})$, title compound was obtained following the same procedure used for $( \pm)-6 \mathrm{a}$. ${ }^{1} \mathrm{H}$ NMR $\left(300 \mathrm{MHz}, \mathrm{CDCl}_{3}\right) \delta 7.28(\mathrm{~m}, 2 \mathrm{H}), 7.15(\mathrm{~d}, J=8.4 \mathrm{~Hz}, 2 \mathrm{H}), 6.88(\mathrm{~m}$, $4 \mathrm{H}), 4.40(\mathrm{~d}, J=1.9 \mathrm{~Hz}, 1 \mathrm{H}), 4.02(\mathrm{~d}, J=1.7 \mathrm{~Hz}, 1 \mathrm{H}), 3.82(\mathrm{~s}, 3 \mathrm{H}), 3.78$ $(\mathrm{s}, 3 \mathrm{H}), 3.67(\mathrm{~m}, 1 \mathrm{H}), 3.02(\mathrm{~m}, 2 \mathrm{H}), 2.56(\mathrm{~m}, 2 \mathrm{H}), 1.82(\mathrm{~m}, 4 \mathrm{H}), 1.32$ $(\mathrm{m}, 1 \mathrm{H})$. ESI-MS $m / z: 367[\mathrm{M}+\mathrm{H}]^{+}$.

(4-((2S,3S)-2-(Benzo[d][1,3]dioxol-5-yl)-3-(4-fluorophenyl)azetidin-1-yl)piperidin-1-yl)(1H-1,2,4-triazol-1-yl)methanone (( \pm$)-7)$. Starting from $1 \mathrm{H}-1,2,4$-triazole $(32 \mathrm{mg}, 0.46 \mathrm{mmol})$ and compound $( \pm)-13(80 \mathrm{mg}, 0.23 \mathrm{mmol})$, the title compound was obtained following the same procedure reported for $( \pm)-\mathbf{4 a}$. The crude was purified by means of flash chromatography (dichloromethane/methanol 10:1) to afford pure compound $( \pm)-7$ as a transparent oil (yield). ${ }^{1} \mathrm{H}$ NMR $\left(300 \mathrm{MHz}, \mathrm{CDCl}_{3}\right) \delta 8.73(\mathrm{~s}, 1 \mathrm{H}), 7.97(\mathrm{~s}, 1 \mathrm{H}), 7.09(\mathrm{~m}, 2 \mathrm{H})$, $6.97(\mathrm{t}, J=8.4 \mathrm{~Hz}, 2 \mathrm{H}), 6.64(\mathrm{~d}, J=7.8 \mathrm{~Hz}, 1 \mathrm{H}), 6.52(\mathrm{~s}, 1 \mathrm{H}), 6.45(\mathrm{~d}, J=$ $7.8 \mathrm{~Hz}, 1 \mathrm{H}), 5.89(\mathrm{~s}, 2 \mathrm{H}), 4.32(\mathrm{br} \mathrm{s}, 1 \mathrm{H}), 3.30-2.52(\mathrm{~m}, 8 \mathrm{H}), 1.88(\mathrm{~d}$, $J=11.6 \mathrm{~Hz}, 2 \mathrm{H}), 1.46-1.26(\mathrm{~m}, 2 \mathrm{H})$. ESI-MS $m / z: 450[\mathrm{M}+\mathrm{H}]^{+}$. Anal. $\left(\mathrm{C}_{24} \mathrm{H}_{24} \mathrm{FN}_{5} \mathrm{O}_{3}\right) \mathrm{C}, \mathrm{H}, \mathrm{N}$.

trans-4-(Benzo[d][1,3]dioxol-5-yl)-3-(4-fluorophenyl)azetidin-2one (( \pm$)-8)$. To a stirred solution of compound $( \pm)-18(50 \mathrm{mg}$, $0.11 \mathrm{mmol})$ in dry tetrahydrofuran $(1.0 \mathrm{~mL})$, a $0.1 \mathrm{~N}$ solution of $\mathrm{SmI}_{2}$ in tetrahydrofuran $(6.6 \mathrm{~mL}, 0.66 \mathrm{mmol})$ was added and the reaction was stirred at $25^{\circ} \mathrm{C}$ under Ar atmosphere for $15 \mathrm{~min}$. A saturated solution of $\mathrm{NaHCO}_{3}$ was added, and the aqueous phase was extracted with ethyl acetate $(3 \times 10.0 \mathrm{~mL})$.The combined organic layers were dried over $\mathrm{Na}_{2} \mathrm{SO}_{4}$, filtered, and evaporated. The crude was purified by means of flash-chromatography on silica gel (1:2 ethyl acetate $/ n$-hexane) to afford pure compound $( \pm)-8(20 \mathrm{mg}, 65 \%$ yield $)$ as a white solid. ${ }^{1} \mathrm{H}$ NMR $\left(300 \mathrm{MHz}, \mathrm{CDCl}_{3}\right) \delta 7.33-7.18(\mathrm{~m}, 2 \mathrm{H}), 7.03(\mathrm{t}, J=8.5 \mathrm{~Hz}, 2 \mathrm{H}), 6.93-$ $6.67(\mathrm{~m}, 3 \mathrm{H}), 6.44(\mathrm{~s}, 1 \mathrm{H}), 5.97(\mathrm{~s}, 2 \mathrm{H}), 4.51(\mathrm{~d}, J=2.4 \mathrm{~Hz}, 1 \mathrm{H}), 4.10$ $(\mathrm{d}, J=2.4 \mathrm{~Hz}, 1 \mathrm{H}) .{ }^{13} \mathrm{C} \mathrm{NMR}\left(75 \mathrm{MHz}, \mathrm{CDCl}_{3}\right) \delta 168.9,162.5(\mathrm{~d}$, $\left.J_{\mathrm{C}-\mathrm{F}}=246.6 \mathrm{~Hz}\right), 148.7,148.1,133.4,130.7\left(\mathrm{~d}, J_{\mathrm{C}-\mathrm{F}}=3.3 \mathrm{~Hz}\right), 129.2$ $\left(\mathrm{d}, J_{\mathrm{C}-\mathrm{F}}=8.1 \mathrm{~Hz}\right), 119.4,116.1\left(\mathrm{~d}, J_{\mathrm{C}-\mathrm{F}}=21.6 \mathrm{~Hz}\right), 108.8,105.9,101.6$, 65.8, 60.5. ESI-MS $m / z: 286[\mathrm{M}+\mathrm{H}]^{+}, 308[\mathrm{M}+\mathrm{Na}]^{+}$. Anal. $\left(\mathrm{C}_{16} \mathrm{H}_{12} \mathrm{FNO}_{3}\right) \mathrm{C}, \mathrm{H}, \mathrm{N}$.

Piperidin-1-yl(1H-1,2,4-triazol-1-yl)methanone (9). To a solution of $1 \mathrm{H}-1,2,4$-triazole $(325 \mathrm{mg}, 4.70 \mathrm{mmol}$ ) in dry dichloromethane $(20.0 \mathrm{~mL})$, phosgene $20 \%$ solution in toluene $(2.3 \mathrm{~mL}, 4.70 \mathrm{mmol})$ and 4-(dimethylamino)pyridine $(1.15 \mathrm{~g}, 9.4 \mathrm{mmol})$ were added and the mixture was stirred at $25^{\circ} \mathrm{C}$ for $1 \mathrm{~h}$. Then a solution of piperidine (19, $230 \mu \mathrm{L}, 2.35 \mathrm{mmol})$ in dry dichloromethane $(5.0 \mathrm{~mL})$ was added and the reaction was stirred under Ar atmosphere for $12 \mathrm{~h}$. The solvent was removed under reduced pressure. The crude was purified by means of chromatography on silica gel (1:1 ethyl acetate/n-hexane) to afford compound 9 (quantitative yield) as a yellow oil. ${ }^{1} \mathrm{H}$ NMR $(300 \mathrm{MHz}$, $\left.\mathrm{CDCl}_{3}\right) \delta 8.75(\mathrm{~s}, 1 \mathrm{H}), 7.99(\mathrm{~s}, 1 \mathrm{H}), 3.74($ br s, $4 \mathrm{H}), 1.71(\mathrm{br} \mathrm{s}, 6 \mathrm{H})$. ESI-MS $m / z: 219[\mathrm{M}+\mathrm{K}]^{+}$. Anal. $\left(\mathrm{C}_{8} \mathrm{H}_{12} \mathrm{~N}_{4} \mathrm{O}\right) \mathrm{C}, \mathrm{H}, \mathrm{N}$.

$\mathrm{N}$-(Benzo[d] [1,3]dioxol-5-ylmethylene)-1-benzylpiperidin-4amine (11a). A solution of 4-amino-1-benzylpiperidine (340 $\mu \mathrm{L}$, $1.66 \mathrm{mmol}$ ) and (3,4-methylendioxy)benzaldehyde (10a) (250 mg,
$1.66 \mathrm{mmol})$ in absolute ethanol $(25.0 \mathrm{~mL})$ was heated at $80^{\circ} \mathrm{C}$ for $12 \mathrm{~h}$. The mixture was cooled to $\mathrm{rt}$, and the solvent was removed under reduced pressure. The crude imine (quantitative yield) was used in the following step without any further purification. ESI-MS $m / z: 323$ $[\mathrm{M}+\mathrm{H}]^{+}$.

$\mathrm{N}$-(3,4-Dimethoxybenzylidene)-1-benzylpiperidin-4-amine (11b). Starting from 4-amino-1-benzylpiperidine $(340 \mu \mathrm{L}, 1.66 \mathrm{mmol})$ and 3,4dimethoxybenzaldehyde $(\mathbf{1 0 b}, 275 \mathrm{mg}, 1.66 \mathrm{mmol})$, the title compound was obtained following the same procedure reported for 11a. ESI-MS $m / z: 339[\mathrm{M}+\mathrm{H}]^{+}$.

$N$-(4-Methoxybenzylidene)-1-benzylpiperidin-4-amine (11c). Starting from 4-amino-1-benzylpiperidine $(340 \mu \mathrm{L}, 1.66 \mathrm{mmol})$ and 4-methoxybenzaldehyde (11c, $200 \mu \mathrm{L}, 1.66 \mathrm{mmol})$, the title compound was obtained following the same procedure reported for 11a. ESI-MS $m / z: 309[\mathrm{M}+\mathrm{H}]^{+}$.

4-(trans-2-(Benzo[d][1,3]dioxol-5-yl)-3-(4-fluorophenyl)azetidin1-yl)-1-benzylpiperidine (( \pm -12). To a stirred suspension of $\mathrm{AlCl}_{3}$ $(205 \mathrm{mg}, 1.54 \mathrm{mmol})$ in dry diethyl ether, cooled to $0{ }^{\circ} \mathrm{C}$, a suspension of $\mathrm{LiAlH}_{4}(97.0 \mathrm{mg}, 2.6 \mathrm{~mL})$ in dry tetrahydrofuran was added and the mixture was stirred for $1 \mathrm{~h}$ under Ar atmosphere. Then $( \pm)-5 \mathrm{a}(200 \mathrm{mg}$, $0.44 \mathrm{mmol}$ ) dissolved in dry tetrahydrofuran was added dropwise and the mixture was stirred for 45 min before adding a solution of $\mathrm{NaOH}$ $10 \%$ in water $(1.0 \mathrm{~mL})$. The reaction was stirred for further $30 \mathrm{~min}$ at $0{ }^{\circ} \mathrm{C}$. The aqueous phase was extracted with ethyl acetate $(3 \times 10.0 \mathrm{~mL})$, and the combined organic layers were dried over $\mathrm{Na}_{2} \mathrm{SO}_{4}$, filtered, and evaporated. The crude was purified by means of flash chromatography on silica gel (1:2 ethyl acetate/ $n$-hexane) to afford compound $( \pm)-12$ $(110 \mathrm{mg}, 56 \%$ yield $)$ as a yellow oil. ${ }^{1} \mathrm{H}$ NMR $\left(300 \mathrm{MHz}, \mathrm{CDCl}_{3}\right) \delta 7.31$ (m, 5H), $7.14(\mathrm{~m}, 2 \mathrm{H}), 7.06(\mathrm{~s}, 1 \mathrm{H}), 6.98(\mathrm{t}, J=8.5 \mathrm{~Hz}, 2 \mathrm{H}), 6.76(\mathrm{dd}$, $J=28.8,7.9 \mathrm{~Hz}, 2 \mathrm{H}), 5.93(\mathrm{~s}, 2 \mathrm{H}), 3.88(\mathrm{~d}, J=8.0 \mathrm{~Hz}, 1 \mathrm{H}), 3.78(\mathrm{t}, J=$ $6.8 \mathrm{~Hz}, 1 \mathrm{H}), 3.47(\mathrm{q}, J=13.2 \mathrm{~Hz}, 2 \mathrm{H}), 3.34(\mathrm{dd}, J=16.3,8.1 \mathrm{~Hz}, 1 \mathrm{H})$, $2.97(\mathrm{~m}, 1 \mathrm{H}), 2.86(\mathrm{~d}, J=11.1 \mathrm{~Hz}, 1 \mathrm{H}), 2.67(\mathrm{~d}, J=11.1 \mathrm{~Hz}, 1 \mathrm{H}), 2.26$ $(\mathrm{t}, J=9.7 \mathrm{~Hz}, 1 \mathrm{H}), 2.05(\mathrm{t}, J=10.8 \mathrm{~Hz}, 1 \mathrm{H}), 1.90(\mathrm{t}, J=10.9 \mathrm{~Hz}, 1 \mathrm{H})$, $1.77(\mathrm{~d}, J=12.2 \mathrm{~Hz}, 1 \mathrm{H}), 1.49(\mathrm{dd}, J=23.8,11.5 \mathrm{~Hz}, 2 \mathrm{H}), 1.23(\mathrm{~m}, 1 \mathrm{H})$. ESI-MS $m / z: 445[\mathrm{M}+\mathrm{H}]^{+}$.

4-(trans-2-(Benzo[d][1,3]dioxol-5-yl)-3-(4-fluorophenyl)azetidin1-yl)piperidine (( \pm$)-13)$. Starting from compound $( \pm)-12(110 \mathrm{mg}$, $0.25 \mathrm{mmol}$ ), the title compound was obtained following the same procedure reported for $( \pm$ )-6a. The crude transparent oil (quantitative yield) was used in the following step without any further purification. ${ }^{1} \mathrm{H}$ NMR $\left(300 \mathrm{MHz}, \mathrm{CDCl}_{3}\right) \delta 7.05(\mathrm{~m}, 2 \mathrm{H}), 6.96(\mathrm{~m}, 2 \mathrm{H}), 6.60(\mathrm{~d}, J=$ $7.9 \mathrm{~Hz}, 1 \mathrm{H}), 6.50(\mathrm{~d}, J=1.3 \mathrm{~Hz}, 1 \mathrm{H}), 6.45(\mathrm{~m}, 1 \mathrm{H}), 5.88(\mathrm{~s}, 2 \mathrm{H}), 3.15-$ $2.53(\mathrm{~m}, 7 \mathrm{H}), 2.45-2.25(\mathrm{~m}, 1 \mathrm{H}), 2.23-2.19(\mathrm{~m}, 1 \mathrm{H}), 2.07-1.81$ (m, 2H), 1.81-1.59 (m, 1H), 1.40-0.99 (m, 2H). ESI-MS $m / z: 393$ $[\mathrm{M}+\mathrm{K}]^{+}$.

3-(Benzo[d]thiazol-2-ylamino)propan-1-ol (15). To a stirred solution of 2-chlorobenzothiazole $(14,790 \mu \mathrm{L}, 6.05 \mathrm{mmol})$ in chlorobenzene $(20.0 \mathrm{~mL})$, 3-amino-1-propanol $(510 \mu \mathrm{L}, 6.66 \mathrm{mmol})$ and DIPEA $(4.2 \mathrm{~mL}, 24.20 \mathrm{mmol}$ ) were added and the mixture was stirred at $130^{\circ} \mathrm{C}$ under Ar atmosphere for $4 \mathrm{~h}$. The reaction was cooled to $25^{\circ} \mathrm{C}$, and the solvent was removed under reduce pressure. Water was added, and the aqueous phase was extracted with ethyl acetate $(3 \times$ $15.0 \mathrm{~mL}$ ). The combined organic layers were dried over $\mathrm{Na}_{2} \mathrm{SO}_{4}$, filtered, and evaporated. Crude title compound was used in the following step without any further purification $\left(1.02 \mathrm{~g}, 81 \%\right.$ yield). ${ }^{1} \mathrm{H}$ NMR $\left(300 \mathrm{MHz}, \mathrm{CDCl}_{3}\right) \delta 7.53(\mathrm{t}, J=8.6 \mathrm{~Hz}, 1 \mathrm{H}), 7.30(\mathrm{dd}, J=7.4,1.2 \mathrm{~Hz}$, $1 \mathrm{H}), 7.09(\mathrm{t}, J=7.6 \mathrm{~Hz}, 1 \mathrm{H}), 5.46(\mathrm{br} \mathrm{s}, 1 \mathrm{H}), 3.85-3.58(\mathrm{~m}, 4 \mathrm{H})$, $1.95-1.75(\mathrm{~m}, 2 \mathrm{H}), 1.63($ br s, $1 \mathrm{H})$. ESI-MS $m / z: 209[\mathrm{M}+\mathrm{H}]^{+}, 231$ $[\mathrm{M}+\mathrm{Na}]^{+}$.

3,4-Dihydro-2H-benzo[4,5]thiazolo[3,2-a]pyrimidine (16). To a stirred solution of alcohol $15(1.02 \mathrm{~g}, 4.90 \mathrm{mmol})$ in dry dichloromethane $(50.0 \mathrm{~mL})$ cooled to $0{ }^{\circ} \mathrm{C}$, TEA $(2.05 \mathrm{~mL}, 14.70 \mathrm{mmol})$ and mesyl chloride $(570 \mu \mathrm{L}, 7.35 \mathrm{mmol})$ were added and the mixture was stirred at $25^{\circ} \mathrm{C}$ under Ar atmosphere for $1.5 \mathrm{~h}$. Methanol $(300 \mu \mathrm{L})$ was added to quench the excess of mesyl chloride, and the reaction was treated with a further amount of TEA $(2.05 \mathrm{~mL}, 14.70 \mathrm{mmol})$ and stirred at $50{ }^{\circ} \mathrm{C}$ for $1.5 \mathrm{~h}$. Water was added, and the aqueous phase was extracted with dichloromethane $(3 \times 15.0 \mathrm{~mL})$. The combined organic layers were dried over $\mathrm{Na}_{2} \mathrm{SO}_{4}$, filtered, and evaporated. The crude was suspended in ethyl acetate and stirred at reflux for $15 \mathrm{~min}$, then $1 \mathrm{~h}$ at 
$25{ }^{\circ} \mathrm{C}$, and finally cooled to $0{ }^{\circ} \mathrm{C}$. The precipitate was filtered and washed with cold ethyl acetate to obtain pure compound 16 (865 mg, $93 \%$ yield) as a dark solid. ${ }^{1} \mathrm{H}$ NMR $\left(300 \mathrm{MHz}, \mathrm{CDCl}_{3}\right) \delta 7.19(\mathrm{t}, J=$ $7.8 \mathrm{~Hz}, 2 \mathrm{H}), 6.99(\mathrm{t}, J=7.6 \mathrm{~Hz}, 1 \mathrm{H}), 6.75(\mathrm{~d}, J=8.0 \mathrm{~Hz}, 1 \mathrm{H}), 3.78(\mathrm{t}, J=$ $6.0 \mathrm{~Hz}, 2 \mathrm{H}), 3.57(\mathrm{t}, J=5.5 \mathrm{~Hz}, 2 \mathrm{H}), 2.10-1.97(\mathrm{~m}, 2 \mathrm{H})$. ESI-MS $m / z$ : $191[\mathrm{M}+\mathrm{H}]^{+}, 213[\mathrm{M}+\mathrm{Na}]^{+}$.

(E)- $N$-(Benzo[d][1,3]dioxol-5-ylmethylene)-4-methylbenzenesulfonamide (17). A solution of 4-toluenesulfonamide $(570 \mathrm{mg}$, $3.33 \mathrm{mmol}$ ) and (3,4-methylendioxy)benzaldehyde (10, $500 \mathrm{mg}$, $3.33 \mathrm{mmol})$ in dry toluene $(20.0 \mathrm{~mL})$ was stirred at $120{ }^{\circ} \mathrm{C}$ before adding $\mathrm{BF}_{3} \cdot \mathrm{Et}_{2} \mathrm{O}(65 \mu \mathrm{L}, 0.53 \mathrm{mmol})$. The reaction was stirred at reflux under $\mathrm{Ar}$ atmosphere for $12 \mathrm{~h}$. The solvent was removed under reduced pressure, and crude imine 17 (quantitative yield) was used in the following step without any further purification. ESI-MS $\mathrm{m} / z: 304$ $[\mathrm{M}+\mathrm{H}]^{+}$.

trans-4-(Benzo[d][1,3]dioxol-5-yl)-3-(4-fluorophenyl)-1-tosylazetidin-2-one (( \pm$)-18)$. To a stirred solution of 4-fluorophenylacetic acid $(89 \mathrm{mg}, 0.58 \mathrm{mmol})$ in dry dichloromethane $(10.0 \mathrm{~mL})$ cooled to $0{ }^{\circ} \mathrm{C}$, tosyl chloride (165 mg, $0.87 \mathrm{mmol})$ and DIPEA $(150 \mu \mathrm{L}, 0.87 \mathrm{mmol})$ were added and the reaction was stirred under $\mathrm{Ar}$ atmosphere for $30 \mathrm{~min}$. Then, a solution of imine $17(150 \mathrm{mg}, 0.58 \mathrm{mmol})$ in dry dichloromethane was added, followed by the addition of catalyst 16 $(23 \mathrm{mg}, 0.12 \mathrm{mmol})$ and DIPEA $(150 \mu \mathrm{L}, 0.87 \mathrm{mmol})$. The mixture was stirred at $25^{\circ} \mathrm{C}$ for $5 \mathrm{~h}$ before adding a $2 \mathrm{~N}$ solution of $\mathrm{HCl}$. The aqueous phase was extracted with dichloromethane $(3 \times 10.0 \mathrm{~mL})$, and the combined organic layers were dried over $\mathrm{Na}_{2} \mathrm{SO}_{4}$, filtered, and evaporated. The crude was purified by means of flash-chromatography on silica gel ( $1: 5$ ethyl acetate $/ n$-hexane) to afford pure compound $( \pm)$-18 (100 mg, 40\% yield) as a slightly yellow oil. ${ }^{1} \mathrm{H}$ NMR $(300 \mathrm{MHz}$, $\left.\mathrm{CDCl}_{3}\right) \delta 7.73(\mathrm{~d}, J=8.4 \mathrm{~Hz}, 2 \mathrm{H}), 7.30(\mathrm{~d}, J=8.0 \mathrm{~Hz}, 2 \mathrm{H}), 7.09-6.93$ $(\mathrm{m}, 4 \mathrm{H}), 6.79-6.73(\mathrm{~m}, 2 \mathrm{H}), 6.67(\mathrm{~s}, 1 \mathrm{H}), 5.97(\mathrm{~s}, 2 \mathrm{H}), 4.83(\mathrm{~d}, J=$ $3.3 \mathrm{~Hz}, 1 \mathrm{H}), 4.20(\mathrm{~d}, J=3.2 \mathrm{~Hz}, 1 \mathrm{H}), 2.45(\mathrm{~s}, 3 \mathrm{H})$. ESI-MS $m / z: 440$ $[\mathrm{M}+\mathrm{H}]^{+}, 462[\mathrm{M}+\mathrm{Na}]^{+}$.

Enzyme Assays. MGL and FAAH activities were detected by using different enzymatic sources. In particular, 2-AG hydrolysis was measured by incubating the $10000 \mathrm{~g}$ cytosolic fraction of the commercially available human recombinant MGL $(0.05 \mu \mathrm{g} / \mathrm{sample}$; Cayman Chemicals, Ann Arbor, MI, USA) in Tris- $\mathrm{HCl} 50 \mathrm{mM}$, at pH 7.0 at $37^{\circ} \mathrm{C}$ for $20 \mathrm{~min}$, with synthetic 2 -arachidonoyl- $\left[{ }^{3} \mathrm{H}\right]$-glycerol $(40 \mathrm{Ci} / \mathrm{mmol}$, ARC St. Louis, MO, USA) properly diluted with 2-AG (Cayman Chemicals, Ann Arbor, MI, USA). After incubation, the amount of $\left[{ }^{3} \mathrm{H}\right]$ glycerol produced was measured by scintillation counting of the aqueous phase after extraction of the incubation mixture with 2 volumes of $\mathrm{CHCl}_{3} / \mathrm{MeOH}$ 1:1 (by vol.). For time-course experiments, the effect of compounds on MGL activity was measured after $10 \mathrm{~min}$ of preincubation with the enzyme followed by a $20 \mathrm{~min}$ of incubation with the specific substrate. AEA hydrolysis was measured by incubating the $10000 \mathrm{~g}$ membrane fraction of rat brain $(70 \mu \mathrm{g} / \mathrm{sample})$ or the commercially available human recombinant FAAH (2 $\mu \mathrm{g} /$ sample; Cayman Chemicals, Ann Arbor, MI, USA) in Tris- $\mathrm{HCl} 50 \mathrm{mM}$, at $\mathrm{pH} 9.5$ at $37{ }^{\circ} \mathrm{C}$ for $30 \mathrm{~min}$, with synthetic $\mathrm{N}$-arachidonoyl- $\left[{ }^{14} \mathrm{C}\right]$ ethanolamine $(110 \mathrm{mCi} / \mathrm{mmol}$, ARC St. Louis, MO, USA) properly diluted with AEA (Tocris Bioscience, Avonmouth, Bristol, UK). After incubation, the amount of $\left[{ }^{14} \mathrm{C}\right]$-ethanolamine produced was measured by scintillation counting of the aqueous phase after extraction of the incubation mixture with 2 volumes of $\mathrm{CHCl}_{3} / \mathrm{MeOH} 1: 1$ (by vol).

Binding Assays. Membranes from HEK-293 cells stably transfected with the human recombinant $\mathrm{CB} 1\left(B_{\max }=2.9 \mathrm{pmol} / \mathrm{mg}\right.$ protein $)$ and human recombinant $\mathrm{CB} 2\left(B_{\max }=6.0 \mathrm{pmol} / \mathrm{mg}\right.$ protein $)$ were incubated with $\left[{ }^{3} \mathrm{H}\right]-\mathrm{CP}-55940\left(0.4 \mathrm{nM} / K_{\mathrm{d}}=0.11 \mathrm{nM}\right.$ and $0.53 \mathrm{nM} / K_{\mathrm{d}}=$ $0.19 \mathrm{nM}$, respectively, for $\mathrm{CB} 1$ and $\mathrm{CB} 2$ ) as the high affinity ligand and displaced with $10 \mu \mathrm{M}$ WIN 55212-2 as the heterologous competitor for nonspecific binding $\left(K_{\mathrm{i}}\right.$ values 8.8 and $0.9 \mathrm{nM}$, respectively, for CB1 and CB2). All compounds were tested following the procedure described by the manufacturer (PerkinElmer, Italia). Displacement curves were generated by incubating drugs with $\left[{ }^{3} \mathrm{H}\right]-\mathrm{CP}-55,940$ for $90 \mathrm{~min}$ at $30^{\circ} \mathrm{C}$.

Mass Studies. MGL Purification. Purified MGL protein was prepared as described by King and co-workers ${ }^{12}$ with minor modification. Briefly, $r$ MGL cDNA was cloned in the $\mathrm{pET} 15 \mathrm{~b}$ vector containing an $\mathrm{N}$-terminal histidine tag (Novagen, La Jolla, CA), and the protein was expressed in Rosetta 2(DE3)pLysS Escherichia coli cells (Novagen) using $1 \mathrm{mM}$ isopropyl- $\beta$-D-thiogalactopyranoside (IPTG). The cells were collected in lysis buffer ( $50 \mathrm{mM}$ HEPES, pH 7.4, $300 \mathrm{mM} \mathrm{NaCl}$, $10 \mathrm{mM} \mathrm{MgCl}_{2}, 3 \mathrm{mM} \beta$-mercaptoethanol, $0.5 \mathrm{mM}$ benzamidine, $10 \mu \mathrm{M}$ $\mathrm{E}-64$, and $10 \mu \mathrm{g} / \mathrm{mL}$ aprotinin), homogenized, and the soluble fraction was loaded onto a TALON column (Clontech, Mountain View, CA) equilibrated with $50 \mathrm{mM}$ HEPES ( $\mathrm{pH} 7.4$ ), $300 \mathrm{mM} \mathrm{NaCl}, 3 \mathrm{mM}$ $\beta$-mercaptoethanol, $0.1 \%$ Triton X-100 (buffer A). After wash, the protein was eluted from the column by using a step gradient of imidazole ranging from 10 to $200 \mathrm{mM}$ imidazole in buffer A.

Incubation of MGL with 4a. Purified $r$ MGL was incubated with $4 a$ at a molar ratio of $1: 10$, for $1 \mathrm{~h}$ at $37^{\circ} \mathrm{C}$. The incubation buffer was the same used for the final MGL purification (buffer A plus imidazole). A reference incubation with DMSO was also included.

Intact MGL Analysis. After incubation, intact MGL was centrifuged ( $10000 \mathrm{~g}$ for $5 \mathrm{~min}$ ). A small aliquot of the supernatant was diluted 10 -fold in water added with $0.1 \%$ formic acid and was analyzed by LC-MS using a Synapt G2 qTOF mass spectrometer coupled with an Acquity UPLC system. The protein was loaded on a BEH C4 column $(1 \mathrm{~mm} \times 100 \mathrm{~mm})$ and eluted with a linear gradient of acetonitrile in water (both added with $0.1 \%$ formic acid). Column and LC-MS/MS system were purchased from Waters, Milford, USA. Mass spectra were acquired in positive ion mode in the $500-4000 \mathrm{~m} / z$ range. Leucine encephalin was infused in the ion source at $2 \mathrm{ng} / \mathrm{mL}$ as lock mass for spectra recalibration.

Bottom-Up Analysis of MGL. After the incubation process reported above, MGL was digested with trypsin (proteomic grade, Sigma, Milano, Italia) at $1: 50$ ratio $(\mathrm{w} / \mathrm{w})$ at $37^{\circ} \mathrm{C}$ for $12 \mathrm{~h}$. After digestion, the sample was centrifuged at $10000 \mathrm{~g}$ for $5 \mathrm{~min}$. A small aliquot of the supernatant was diluted 10 -fold in water added with $0.1 \%$ formic acid and was analyzed by LC-MS/MS using the same system described above. The column was a BEH C18 $(1 \mathrm{~mm} \times 100 \mathrm{~mm})$ purchased from Waters. Peptides were eluted with a $12 \mathrm{~min}, 3-60 \%$ gradient of acetonitrile in water. Tandem mass data were acquired in data dependent acquisition mode, selecting multiple charged states as precursors. Collision energy was automatically set by the acquisition software (Supporting Information, Figure S3). We incubated the purified MGL with 4 a, or control DMSO, at a molar ratio of $1: 10$ for $1 \mathrm{~h}$ at $37^{\circ} \mathrm{C}$. Then, the proteins were digested with trypsin at $37^{\circ} \mathrm{C}$ for $12 \mathrm{~h}$, and the tryptic fragments were analyzed by LC-MS/MS as described above (Supporting Information, Figure S4). We compared the mass spectra of the native peptide $(\mathrm{m} / z=1067$, red) and the modified peptide from the 4a-treated MGL $(m / z=1146$, green). Compared to the fragments from naive MGL, 4a adducts display a mass increase of $395 \mathrm{Da}$ (Supporting Information, Figure S5). The amino acid sequence shown on the top corresponds to MGL tryptic peptide 110-160, bearing six serine residues. MS/MS spectra of $m / z 1067$ (naïve, bottom) and $m / z$ 1146 (4a adduct, top) both display the y fragment ion series for a part of the peptide, as indicated in Figure S5. From this analysis, three Ser residues are excluded from being the binding site of compound $\mathbf{4 a}$ (Supporting Information, Figure S6). Following a closer investigation of the tandem mass spectra, two internal acylium ions were found. These ions are unmatched between MS/MS spectra of $m / z 1067$ (naïve) and $m / z 1146$ (4a adduct). In particular, the presence of internal acylium ion EVPVFLLGHS(+395)MGG in the $\mathbf{4 a - a d d u c t ~ t a n d e m ~ m a s s ~ s p e c t r u m ~}$ only indicates that compound $4 \mathrm{a}$ binds to the catalytic Ser122 as represented in Figure 2C.

Chiral Resolution of Amine ( \pm )-6a. Racemic mixture ( \pm )-6a was separated by using a cellulose-carbamate (OD) column (Daicel) eluted with a mixture of $50 \%$ of 2 -propanol in $n$-hexane as eluent, flow $1 \mathrm{~mL} / \mathrm{min}$, injection volume $50 \mu \mathrm{L}$. This method allowed us to efficiently split the two enantiomers that were collected and analyzed before the calculation of the $\alpha$-value. The first peak of the chromatogram corresponds to the $(+)$-enantiomer $\left([\alpha]_{20} \mathrm{D}=+68.88\right)$, and the second one was the $(-)$-enantiomer $\left([\alpha]_{20}{ }^{D}=-69.05\right)$ (Supporting Information, Figure S2). Both the fractions were analyzed after collection to check their optical purity. The analytical conditions were identical to those above-described for the racemate separation. In Supporting Information, Figure S2 are reported the chromatograms obtained for respectively $(+)-6 \mathbf{a}$ and $(-)-6 \mathbf{a}$. 
Stereochemical Characterization of (+)-trans-6a. Experimental $\mathrm{ECD}$ and UV spectroscopic analysis was carried out at $25^{\circ} \mathrm{C}$ on a Jasco (Tokyo, Japan) J-810 spectropolarimeter equipped with a PTC-423S Peltier-type temperature control system, using a $2 \mathrm{~nm}$ spectral bandwidth, a $50 \mathrm{~nm} \mathrm{~min}^{-1}$ scanning speed, and a $2 \mathrm{~s}$ data integration time; spectra were averaged over three accumulation cycles. Quartz cells (Hellma, Milan, Italy) with a $1 \mathrm{~mm}$ path length were used to measure spectra in the 320-200 $\mathrm{nm}$ spectral range. Samples for electronic ECD and UV spectroscopic analysis on (+)-trans-6a were prepared using HPLC-grade 2-propanol (Sigma-Aldrich, Milan, Italy) at a $135 \mu \mathrm{M}$ concentration.

Computational Spectroscopy. The theoretical chiroptical properties of $(3 R, 4 S)$-6a (Supporting Information, Figure S8) were determined according to the standard protocol for stereochemical characterization by time-dependent density functional theory (TD-DFT) calculations. ${ }^{33}$ A preliminary conformational search was performed by molecular mechanics (MM) calculations using the MMFF94s force field ${ }^{34}$ and the Spartan'02 software (Spartan'02 Wave function, Inc., Irvine, CA, 2002). DFT geometry optimization and frequency calculations were carried out on the 15 conformers, labeled $(R, S)-6 \mathbf{a} 1-6 a 15$, having relative MM energy $\left(\Delta E_{\mathrm{MM}}\right)$ below $3 \mathrm{kcal} \mathrm{mol}^{-1}$, using the Gaussian 09 software (Gaussian09, Revision C.01; Gaussian Inc.: Wallingford CT, 2010). The B97D functiona ${ }^{35}$ the TZ2P basis set consisting in Dunning's [ $5 \mathrm{~s} 3 \mathrm{p} / 3 \mathrm{~s}$ ] contraction of Huzinaga's primitive $[10 \mathrm{~s} 6 \mathrm{p} / 5 \mathrm{~s}]$ set with two sets of polarization functions $\left(\alpha_{p}=1.5,0.375\right.$ for $\mathrm{H} ; \alpha_{d}=1.5,0.375$ for $\mathrm{C}$; $\alpha_{d}=$ 1.6, 0.4 for $\mathrm{N} ; \alpha_{d}=1.7,0.425$ for O; $\alpha_{d}=2.0,0.5$ for F) and the IEFPCM solvation model $^{36}$ for 2-propanol were employed. Conformational clustering was performed with a RMSD threshold value of $0.01 \AA$ for heavy atoms; conformer $(R, S)$-6a4 converged to the same geometry as conformer $(R, S)$-6al and was consequently not considered in further calculations. A detailed structural description of conformers $(R, S)-6 \mathbf{a} 1-$ 6a15 is given in Supporting Information, Tables S2 and S3 and Figure S9, while thermodynamic data are reported in Supporting Information, Table S4; the optimized structure of the lowest-energy conformer of $(3 R, 4 S)-6 \mathbf{a}$ and $(R, S)-6 \mathbf{1 3}$, is depicted in Supporting Information, Figure S10. TD-DFT calculations were also carried out using the Gaussian 09 software (Gaussian09, Revision C.01; Gaussian Inc.: Wallingford CT, 2010). The PBE0 functional ${ }^{37,38}$ was used in combination with the TZ2P basis set and the IEFPCM solvation model for 2-propanol; calculations were performed on all optimized conformers. Theoretical values of oscillator strength $\left(f_{j}\right)$, rotational strength in dipole velocity formalism $\left(R_{\mathrm{j}}\right)$, and excitation energies (expressed as wavelengths, $\lambda_{j}$ ) were calculated for the 50 lowest-energy electronic transitions of each optimized conformer and are reported in Supporting Information, Tables S5 and S6. The theoretical spectra of optimized conformers were then derived by approximation of $f_{j}$ and $R_{j}$ values to Gaussian bands with a $\Delta \sigma$ value of $0.25 \mathrm{eV} .^{39}$ The theoretical UV and ECD spectra of $(3 R, 4 S)$-6a were finally derived as the weighted average of the contribution of all conformers, according to their equilibrium populations at $298.15 \mathrm{~K}$ and $1 \mathrm{~atm}(\chi)$ as determined by Boltzmann statistics based on relative free energies $(\Delta G)$ and compared to the experimental spectra (Figure 1).

Computational Studies. All calculations performed in this work were carried out on two Cooler Master Centurion 5 (Intel Core-i5 Quad CPU Q6600@ @.40 GHz) with Ubuntu 10.04 LTS (long-term support) operating system running Maestro 9.2 (Schrödinger, LLC, New York, NY, 2011) and GOLD 5.2 (The Cambridge Crystallographic Data Centre, Cambridge, UK). All the pictures presented in this study were generated by PyMOL (PyMOL v1.6-alpha; Schrödinger, LLC, New York, 2013).

Molecules Preparation. Three-dimensional structures of both enantiomers of compound ( \pm -4a were built by means of Maestro (Maestro, version 9.2, Schrödinger, LLC, New York, NY, 2011). Molecular energy minimizations were performed by means of MacroModel using the Optimized Potentials for Liquid Simulationsall atom (OPLS-AA) force field 2005 . $^{40}$ The solvent effects are simulated using the analytical Generalized-Born/Surface Area (GB/SA) model, ${ }^{41}$ and no cutoff for nonbonded interactions was selected. Polak-Ribiere conjugate gradient (PRCG) method with 1000 maximum iterations and 0.001 gradient convergence threshold was employed. Compound 4a was treated by LigPrep application (LigPrep, version 2.5, Schrödinger, LLC, New York, NY, 2011), implemented in Maestro suite 2011, generating the most probable ionization state of any possible enantiomers and tautomers at cellular $\mathrm{pH}$ value $(7 \pm 0.5)$.

Protein Preparation. The three-dimensional structures of the $h \mathrm{MGL}$ and $h$ FAAH were taken from PDB ( $h$ MGL PDB ID, 3PE $6{ }^{42} h$ FAAH $\mathrm{PDB}$ ID, $3 \mathrm{PPM}^{43}$ ) and imported into Schrödinger Maestro molecular modeling environment. The structures were submitted to Protein Preparation Wizard implemented in Maestro suite 2011 (Protein Preparation Wizard workflow 2011). This protocol, through a series of computational steps, allowed us to obtain a reasonable starting structure of the proteins for molecular docking calculations by a series of computational steps. In particular, we performed three steps to (1) add hydrogens, (2) optimize the orientation of hydroxyl groups, Asn, and Gln, and the protonation state of His, and (3) perform a constrained refinement with the impref utility, setting the max RMSD of 0.30 . The impref utility consists of a cycles of energy minimization based on the impact molecular mechanics engine and on the OPLS_2005 force field. ${ }^{40}$

Noncovalent Docking. Noncovalent docking studies were carried out by Glide (Grid-Based Ligand Docking with Energetics) (Glide, version 5.7, Schrödinger, LLC, New York, 2011) using the ligands and proteins prepared as above-mentioned, applying Glide extra precision (XP) method, as previously reported. ${ }^{44}$ Energy grids were prepared using default value of protein atom scaling factor $(1.0 \AA)$ within a cubic box centered on the catalytic Ser122 (for hMGL) and Ser241 (for $h \mathrm{FAAH}$, Figure 5 ). After grid generation, the ligands were docked into the enzymes with default parameters (no constraints were added). The number of poses entered to postdocking minimization was set to 50. Glide XP score was evaluated.

Covalent Docking. Concerning the covalent docking available in GOLD 5.2 program, ${ }^{23}$ the representative poses of the most populated cluster of docked solutions obtained by Glide for both enantiomers of compound 4a into $h \mathrm{MGL}$ enzyme were redocked into binding site, through a covalent linkage between electrophilic carbon atom close to the triazole moiety and the hydroxyl side chain of the catalytic residue (Ser122). In fact, both protein and ligand files were set up with the link atom included. During docking runs, the link atom in the ligand is forced to fit onto the link atom in the protein. To ensure that the geometry of the bound ligand was correct, an angle-bending energy term for the link atom was included in the calculation of the fitness score. ${ }^{45}$ Both enantiomers of compound $4 \mathrm{a}$ was docked 50 times with early termination if the top three poses were within $1.5 \AA$ RMSD. The obtained $h \mathrm{MGL}-$ $(3 R, 4 S)-\mathbf{4 a}$ and $h \mathrm{MGL}-(3 S, 4 R)-\mathbf{4 a}$ tetrahedral complexes was energy minimized using MacroModel using the Optimized Potentials for Liquid Simulations-All Atom (OPLS-AA) force field $2005 .^{40}$ The solvent effects are simulated using the analytical Generalized-Born/ Surface Area (GB/SA) model, ${ }^{41}$ and no cutoff for nonbonded interactions was selected. Polak-Ribiere conjugate gradient (PRCG) method with 100000 maximum iterations and 0.001 gradient convergence threshold was employed.

Free-Binding Energies Calculation. The Prime/MM-GBSA method implemented in Prime software (Prime, version 3.0, Schrödinger, LLC, New York, 2011) consists in computing the change between the free and the complex state of both the ligand and the protein after energy minimization. The technique was used on the docking complexes ( $h$ MGL$(3 R, 4 S)-\mathbf{4 a}$ and $h \mathrm{MGL}-(3 S, 4 R)-\mathbf{4 a} ; h$ FAAH- $(3 R, 4 S)-\mathbf{4 a}$ and $h$ FAAH$(3 S, 4 R)-4 a)$ in order to calculate the free-binding energy $\left(\Delta G_{\text {bind }}\right)$. Prime/MM-GBSA was used employing the calculation of ligand strain energies and using the minimization as sampling method, defining as flexible residues, those comprised in $10 \AA$ from the ligand.

Selectivity in an Affinity-Based Proteomic Profiling (ABPP) Assay. Rat brain membranes were prepared according to previously reported methods and diluted to $1 \mathrm{mg} / \mathrm{mL}$ prior to use. ${ }^{46}$ Proteomes $(50 \mu \mathrm{L})$ were preincubated with either DMSO or $1-1000 \mathrm{nM}$ concentrations of inhibitor at $37^{\circ} \mathrm{C}$. After $20 \mathrm{~min}, \mathrm{FP}-\mathrm{Rh}(1.0 \mu \mathrm{L}$, $50 \mu \mathrm{M}$ in DMSO, a kind gift of Ben Cravatt) was added and the mixture was incubated for another $30 \mathrm{~min}$ at $37^{\circ} \mathrm{C}$. Reactions were quenched with SDS loading buffer $(12.5 \mu \mathrm{L}, 5 \times)$ and run on SDS-PAGE (sodium dodecyl sulfate polyacrylamide gel electrophoresis). ${ }^{47}$ Following gel 
imaging, serine hydrolase activity was determined by measuring fluorescent intensity of gel bands corresponding to MAGL, ABHD6, and FAAH using Image $1.43 \mathrm{u}$ software.

Mutagenicity Studies and Pharmacokinetic Profiling Procedures. Ames Test. Ames test was performed as previously described. ${ }^{48}$

Solubility and Chemical Stability. Standard and sample solutions are prepared from a $10 \mathrm{mM}$ DMSO stock solution using an automated dilution procedure. For compound $\mathbf{4 a}$, three solutions are prepared; one to be used as standard and the other two as test solutions.

- Standard: $250 \mu \mathrm{M}$ standard solution in acetonitrile/buffer, with a final DMSO content of $2.5 \%(\mathrm{v} / \mathrm{v})$.

- Test sample for $\mathrm{pH}$ 3.0:250 $\mu \mathrm{M}$ sample solution in acetic acid $50 \mathrm{mM}, \mathrm{pH}=3$, with a final DMSO content of $2.5 \%(\mathrm{v} / \mathrm{v})$.

- Test sample for $\mathrm{pH}$ 7.4: a $250 \mu \mathrm{M}$ sample solution in ammonium acetate buffer $50 \mathrm{mM}, \mathrm{pH}=7.4$, with a final DMSO content of $2.5 \%(\mathrm{v} / \mathrm{v})$.

The $250 \mu \mathrm{M}$ product suspensions/solutions in the aqueous buffers are prepared directly in Millipore MultiScreen-96 filter plates $(0.4 \mu \mathrm{m}$ PTCE membrane) and sealed. Plates are left for $24 \mathrm{~h}$ at $\mathrm{rt}$ under orbital shaking to achieve "pseudo-thermodynamic equilibrium" and to presaturate the membrane filter. Product suspensions/solutions are then filtered using centrifugation, diluted 1:2 with the same buffer solution, and analyzed by UPLC/UV/TOF-MS, using UV-detection at $254 \mathrm{~nm}$ for quantitation. An aliquot of the $\mathrm{pH} 7.4$ solution is transferred in a microplate, left for $24 \mathrm{~h}$ at $\mathrm{rt}$, and analyzed by UPLC/UV/TOF-MS for the chemical stability assay.

Metabolic Stability on Human CYP3A4. Compound 4a in $10 \mathrm{mM}$ DMSO solution was added to an incubation mixture in a 96-well microplate containing $20 \mathrm{pmol} / \mathrm{mL}$ of $h$ CYP $3 A 4(0.1-0.2 \mathrm{mg} / \mathrm{mL}$ protein). The mixture is split in two aliquots: one receiving a NADPH regenerating system, the other an equal amount of phosphate buffer. The final substrate concentration is $1 \mu \mathrm{M}$ along with $0.25 \%$ of organic solvent. Incubation proceeds for $1 \mathrm{~h}$ at $37^{\circ} \mathrm{C}$ and is then stopped by addition of $\mathrm{MeCN}$ to precipitate proteins.

Permeability Assay (PAMPA). Compound 4a $(10 \mu \mathrm{M}$ in HBSS + Hepes buffer) are added to the donor chamber and incubated (together with a reference compound, warfarin, to verify membrane integrity) for $4 \mathrm{~h}$ at $37^{\circ} \mathrm{C}$ and $80 \%$ humidity. Concentrations of reference, donor, and acceptor solutions are measured by UPLC-MS-TOF (references, donor, and acceptor are injected in UPLC-MS in this order for compare the MS quantitative signal).

Brain Penetration. Transport across the blood-brain barrier was tested using a human in vitro blood-brain barrier model consisting of a coculture of endothelial cells derived from hematopoietic stem cells and pericytes. ${ }^{49}$ After 6 days of coculture, compound $4 a$ ( $100 \mu \mathrm{M}$ in Ringer solution + Hepes) was added to the luminal side of endothelial cells (together with a nonpermeant compound, Lucifer yellow, to verify endothelium integrity) and incubated for 20,40 , and $60 \mathrm{~min}$ at $37^{\circ} \mathrm{C}$ and $80 \%$ humidity. Concentrations were measured at luminal and abluminal sides using fluorescence detection (synergy $\mathrm{H} 1$ multiplates reader; BioTek) for Lucifer yellow and LC-UV analysis for 4a. $P_{\text {app }}$ was determined according the equation $P_{\text {app }}=J / A C o$, where $J$ is the rate of appearance of the drug at the abluminal side, Co is the initial concentration at the luminal side, and $A$ is the surface area of the filter. ${ }^{50}$

Isolated Rat Heart Preparation and Perfusion. All animal care and experimental protocols conformed to the European Union Guidelines for the Care and the Use of Laboratory Animals (European Union Directive 2010/63/EU) and were approved by the Italian Department of Health (666/2015-PR). Male Sprague-Dawley rats ( 300 g; Charles River Italia, Calco, Italy) were anaesthetized (ip) with a mixture of Zoletil $100\left(7.5 \mathrm{mg} \mathrm{kg}{ }^{-1}\right.$ tiletamine and $7.5 \mathrm{mg} \mathrm{kg}{ }^{-1}$ zolazepam; Virbac Srl, Milano, Italy) and Xilor ( $4 \mathrm{mg} / \mathrm{kg}$ xylazine; Bio 98, San Lazzaro, Italy) containing heparin $(5000 \mathrm{U} / \mathrm{kg})$, decapitated, and bled. The hearts, spontaneously beating, were rapidly explanted and mounted on a Langendorff apparatus for retrograde perfusion via the aorta at a constant flow rate of $10 \mathrm{~mL} / \mathrm{min}$ with a Krebs-Henseleit solution of the following composition (mM): $\mathrm{NaCl} 118, \mathrm{KCl} 4.7, \mathrm{CaCl}_{2}$ 2.5, $\mathrm{MgSO}_{4} 1.2, \mathrm{NaHCO}_{3} 25, \mathrm{KH}_{2} \mathrm{PO}_{4} 1.2$, glucose 11.5, Na pyruvate 2, and EDTA 0.5, bubbled with a $95 \% \mathrm{O}_{2}-5 \% \mathrm{CO}_{2}$ gas mixture (pH 7.4), and kept at $37^{\circ} \mathrm{C}$, as described elsewhere. ${ }^{51}$

The hearts were allowed to equilibrate for at least $20 \mathrm{~min}$ before drug exposure.

Heart contractility was measured as left ventricle pressure (LVP) by means of latex balloon, inserted into the left ventricle via the mitral valve and connected to a pressure transducer (BLPR, WPI, Berlin, Germany). The balloon was inflated with deionized water from a microsyringe until a left ventricular end diastolic pressure of $10 \mathrm{mmHg}$ was obtained.

Alteration in coronary perfusion pressure (CPP), arising from changes in coronary vascular resistance, were recorded by pressure transducer (BLPR, WPI, Berlin, Germany) placed in the inflow line.

A surface electrocardiogram (ECG) was recorded at a sampling rate of $1 \mathrm{kHz}$ by means of two steel electrodes, one placed on the apex and the other on the left atrium of the heart. The ECG analysis included the following measurements: RR (cycle length), HR (frequency), PQ (atrioventricular conduction time), QRS (intraventricular conduction time), and QT (overall action potential duration). ${ }^{52}$

LVP, CPP, and ECG were recorded with a digital PowerLab data acquisition system (PowerLab 8/30; ADInstruments, Castle Hill, Australia) and analyzed by using Chart Pro for Windows software (PowerLab; ADInstruments, Castle Hill, Australia).

LVP was calculated by subtracting the left ventricular diastolic pressure from the left ventricular systolic pressure. As the QT interval is affected by heart rate changes (e.g., it shortens with rapid heart rate), Bazett's formula $\left(\mathrm{QTc}=\mathrm{QT} /(\mathrm{RR})^{1 / 2}\right)$ was routinely used to avoid confounding effects.

Compound 4a was dissolved in DMSO. Solvents failed to alter the response of the preparations (data not shown).

Statistical Analysis. Data are reported as mean \pm SEM; $n$ (indicated in parentheses) represents the number of rat hearts. Analysis of data was accomplished using GraphPad Prism version 5.04 (GraphPad Software, U.S.A.). Statistical analyses and significance as measured by repeated measures ANOVA (followed by Dunnett's post test) were obtained using GraphPad InStat version 3.06 (GraphPad Software, U.S.A.). In all comparisons, $P<0.05$ was considered significant.

Pharmacological in Vivo Studies. Animal handling was carried out according to the European Community guidelines for animal care (DL 116/92, application of the European Communities Council Directive $86 / 609 / E E C)$. The ethical policy of the University of Florence and the Second University of Naples conforms with the Guide for the Care and Use of Laboratory Animals of the U.S. National Institutes of Health (NIH Publication no. 85-23, revised 1996; University of Florence assurance number A5278-01). Formal approval to conduct the experiments described herein was obtained from the animal subjects review board of the University of Florence and Second University of Naples.

Formalin Experiments. For the formalin experiments, male CD-1 mice received formalin $(1.25 \%$ in saline, $30 \mu \mathrm{L})$ in the dorsal surface of one side of the hind paw. Each mouse was randomly assigned to one of the experimental groups $(n=6)$ and placed in a plexiglass cage and allowed to move freely for $15-20 \mathrm{~min}$. A mirror was placed at a $45^{\circ}$ angle under the cage to allow full view of the hind paws. Lifting, favoring, licking, shaking, and flinching of the injected paw were recorded as nociceptive responses. ${ }^{53}$ The total time of the nociceptive response was measured every $5 \mathrm{~min}$ and expressed in min (mean \pm SEM). Recording of nociceptive behavior commenced immediately after formalin injection and was continued for $60 \mathrm{~min}$. Mice received vehicle $(0.5 \%$ DMSO in saline) or different doses of $4 \mathbf{a}(0.1$ or $0.3 \mathrm{mg} / \mathrm{kg}$, ip) $10 \mathrm{~min}$ before formalin injection. For the combination experiments, 20 or 21 $(1 \mathrm{mg} / \mathrm{kg}$, ip) were injected before $4 \mathrm{a}$. For the oxyplatin experiment, male Swiss albino mice $(23-25 \mathrm{~g})$ were used. The animals were fed with a standard laboratory diet and tap water ad libitum and kept at $23 \pm 1{ }^{\circ} \mathrm{C}$ with a $12 \mathrm{~h}$ light/dark cycle, light on at 7 a.m.

Extraction, Purification, and Analysis of 2-AG Tissue Levels. Methods. Tissues (paw skin or spinal cords) from vehicle/saline, vehicle/formalin, compound $1 \mathrm{a} /$ saline, and compound $4 \mathrm{a} /$ formalintreated mice were homogenized in 5 volumes of chloroform/methanol/ Tris $\mathrm{HCl} 50 \mathrm{mM}(2: 1: 1)$ containing 20 pmol each of d5-2-AG. Homogenates were centrifuged at $13000 \mathrm{~g}$ for $16 \mathrm{~min}\left(4{ }^{\circ} \mathrm{C}\right)$, and the 
aqueous phase plus debris was collected and extracted again twice with 1 volume of chloroform. The organic phases from the three extractions were pooled and the organic solvents evaporated in a rotating evaporator. Lyophilized samples were then stored frozen at $-80{ }^{\circ} \mathrm{C}$ under nitrogen atmosphere to be analyzed later. Lyophilized extracts were resuspended in chloroform/methanol 99:1 by volumes. The solutions were then purified by open bed chromatography on silica as described. ${ }^{54}$ Fractions eluted with chloroform/methanol 9:1 by volume (containing 2-AG) were collected, the excess solvent evaporated with a rotating evaporator, and aliquots analyzed by isotope dilution liquid chromatography/atmospheric pressure chemical ionization/mass spectrometry (LC-MS) carried out under conditions described previously and allowing the gross purification of 2-AG. Mass spectrometric detection was carried out in the selected ion monitoring mode using $\mathrm{m} / z$ values of 384 and 379 (molecular ions +1 for deuterated and undeuterated 2-AG). The areas of the peaks corresponding to the 1(3)-and 2-isomers of 2-AG were added together. The amounts of the compounds were expressed as picomol/milligram of tissue.

Oxaliplatin Experiments. Oxaliplatin, a third-generation platinum analogue, has become a first-line chemotherapy in metastatic colorectal cancer and a valid option as adjuvant therapy in several types of cancer. ${ }^{55}$ The major dose-limiting side effect is a painful neuropathy that persists between cycles ${ }^{56}$ and correlated with characteristic alterations of the nervous system. Oxaliplatin neuropathy was induced in mice administering $2.4 \mathrm{mg} / \mathrm{kg}$ oxaliplatin intraperitoneally (ip) for 5 consecutive days every week for 2 weeks (we followed Cavaletti protocol ${ }^{57}$ adapted to mice). Oxaliplatin was dissolved in $5 \%$ glucose solution. Control animals received an equivalent volume of $5 \%$ glucose ip (vehicle). Behavioral tests were performed on day $14.4 a(1-30 \mathrm{mg} / \mathrm{kg})$ was suspended in the vehicle (1\% carboxymethylcellulose) and per os (po) acutely administered on day 14 . Alternatively, $4 \mathrm{a}(10 \mathrm{mg} / \mathrm{kg})$ was daily administered starting from the first day of oxaliplatin treatment to day 13; behavioral measurements were performed $24 \mathrm{~h}$ after the last administration. For analgesia measurements performed by Hot plate test, animals were acutely po treated $(4 \mathrm{a}, 3$ and $10 \mathrm{mg} / \mathrm{kg})$.

Cold and Hot Plate Tests. The cold plate test was performed placing animals in a stainless box $(12 \mathrm{~cm} \times 20 \mathrm{~cm} \times 10 \mathrm{~cm})$ with a cold plate as floor. The temperature of the cold plate was kept constant at $4{ }^{\circ} \mathrm{C} \pm 1{ }^{\circ} \mathrm{C}$. Pain-related behaviors (i.e., lifting and licking of the hind paw) were observed, and the time (s) of the first sign was recorded. The cutoff time of the latency of paw lifting or licking was set at $60 \mathrm{~s}$.

Hot-plate test (Supporting Information, Table S1) was carried out accordingly with O'Callaghan and Holzman. ${ }^{58}$ Mice were placed inside a stainless steel container, thermostatically set at $52.5 \pm 0.1{ }^{\circ} \mathrm{C}$ in a precision water-bath from KW Mechanical Workshop, Siena, Italy. Reaction times (s) were measured with a stop-watch before and at regular intervals up to a maximum of $60 \mathrm{~min}$ after treatment. The end point used was the licking of the fore or hind paws. Before treating animals with $\mathbf{4 a}$, a pretest was performed: those mice scoring below 12 and over $18 \mathrm{~s}$ were rejected. An arbitrary cutoff time of $45 \mathrm{~s}$ was adopted.

Animals and EAE Induction. Female mice (C57BL/6J; 18-20 g, 6-8 weeks) were obtained from Charles River (Calco, Italy) and were housed in the animal facility of DIFAR, Section of Pharmacology and Toxicology (authorization no. 484 of June 8, 2004). Female mice were immunized according to a standard protocol previously described, ${ }^{59}$ with minor modifications. Briefly, animals were subcutaneously injected with incomplete Freund's adjuvant containing $4 \mathrm{mg} / \mathrm{mL}$ Mycobacterium tuberculosis (strain $\mathrm{H} 37 \mathrm{Ra}$ ) and $200 \mu \mathrm{g}$ of the $\mathrm{MOG}_{35-55}$ peptide. Immunization with $\mathrm{MOG}_{35-55}$ was followed by ip administration of 250 $\mathrm{ng}$ of pertussis toxin on day 0 and after $48 \mathrm{~h}$. Clinical scores $(0=$ healthy, $1=\operatorname{limp}$ tail, 2 = ataxia and/or paresis of hindlimbs, $3=$ paralysis of hindlimbs and/or paresis of forelimbs, $4=$ tetraparalysis, $5=$ moribund or death) were recorded daily. All efforts were made to minimize animal suffering and to use the minimal number of animals necessary to produce reliable results.

All the experimental procedures described here were in accordance with the Italian legislation (no. 26, March 4, 2014) and the European legislation (2010/63/UE, September 22, 2010) and the ARRIVE guidelines, and they were approved by the Italian Ministry of Health (protocol number no. 50/2011-B). Experiments were performed following the Guidelines for Animal Care and Use of the National Institutes of Health.

Histological Analysis. Luxol Fast Blue (LFB). Luxol Fast Blue is an histological staining for myelin.

Spinal cord were formalin-fixed and cryoprotected in a 20 and $30 \%$ sucrose solution. Spinal cords were cut with a cryostat, and $10 \mu \mathrm{m}$ thick coronal sections were collected. Tissue sections were immersed overnight in $0.1 \%$ Luxol Fast Blue solution (Solvent Blue 38, SigmaAldrich, St. Louis, MO, USA) at $56-60{ }^{\circ} \mathrm{C}$. Sections were rinsed in deionized water. Differentiation was initiated with immersion in $0.05 \%$ aqueous lithium carbonate for $15-17 \mathrm{~s}$, followed by differentiation in multiple immersions in fresh $70 \%$ ethanol until gray, and white matter could be distinguished and nuclei decolourized. After washing in deionized water, sections were immersed in $0.8 \%$ periodic acid (SigmaAldrich, St Louis, MO, USA) for $10 \mathrm{~min}$ and then rinsed in distillated water. Sections were incubated with Schiffs Reagent (Bio Optica, Milan, Italy) for $20 \mathrm{~min}$, dehydrated in 50 and $100 \%$ ethanol and xylene $(3 \times 1 \mathrm{~min}$ each $)$, and finally coverslipped. Sections were examined using an Olympus BX40 microscope and photographed using a digital camera Olympus DP50 (Olympus, Milan, Italy).

Immunofluorescence Staining. IBA1. Formalin-fixed cryostat sections $(10 \mu \mathrm{m})$ were washed $3 \times$ phosphate-buffered saline (PBS) and $0.3 \%$ Triton X-100 for $5 \mathrm{~min}$ and then were incubated, at room temperature, for $1 \mathrm{~h}$ in blocking solution (PBS, 0.3\% Triton X-100, 5\% albumin bovine serum; PBST). Slices were incubated overnight at $4{ }^{\circ} \mathrm{C}$ in PBST containing rabbit primary antibody directed against ionized calcium binding adapter molecule 1 (Iba1; rabbit, 1:1000; Wako, Richmond, VA, USA) for microglial staining. The following day, slides were washed $3 \times$ PBS, $0.3 \%$ Triton X-100 for 5 min and then sections were incubated in goat antirabbit IgG secondary antibody labeled with Alexa Fluor 568 (1:500; Invitrogen, Carlsbad, USA) and DAPI (4',6-diamidin-2-fenilindolo; 1:2000; Life Technologies-Thermo scientific, Rockford, IL, USA), a nuclei marker, in PBST at room temperature for $2 \mathrm{~h}$, in the dark. After $3 \times$ PBS $0.3 \%$ Triton X-100 wash for $10 \mathrm{~min}$, slices were mounted using ProLong Gold (Life Technologies-Thermo scientific, Rockford, IL, USA) as a mounting medium.

Negative control sections (no exposure to the primary antisera) were processed concurrently with the other sections for immunohistochemical studies in order to exclude the presence of nonspecific immunofluorescent staining or cross-immunostaining.

Images were acquired by using an Olympus BX63 microscope equipped with an Olympus XM10 camera and coupled to CellSense Dimension Software (Olympus, Milan, Italy).

Quantitative analysis of Iba1-positive cells was performed by collecting a field through a $10 \times 0.25 \mathrm{NA}$ objective in the white matter anterior fasciculus of three mice spinal cord for group. Iba1-positive cells were counted in the anterior fasciculus using the "cell counter" plugin of ImageJ (NIH, Bethesda, Maryland, USA).

Statistical Analysis for Histological Measurements. Number of Ibal positive cells/optic field are performed on three rats per group, evaluating section of anterior fasciculus in the white matter spinal cord for each animal. Data are expressed as mean \pm SEM and One-Way ANOVA followed by Bonferroni's post hoc comparison test was performed. Data were analyzed using the Origin 8.1 software (OriginLab, Northampton, USA). Differences were considered significant at a $P<0.05$.

Drug Treatments. Starting at 6 days post immunization (dpi), mice were randomly assigned to the following groups: untreated EAE mice, 4a (3 mg/kg ip)-treated EAE mice; 4 a (3 mg/kg ip)/20 (1 mg/kg)treated EAE mice; $\mathbf{4 a}(3 \mathrm{mg} / \mathrm{kg}$ ip $) / \mathbf{2 1}(1 \mathrm{mg} / \mathrm{kg})$-treated $\mathrm{EAE}$ mice. 20 and 21 were administered $10 \mathrm{~min}$ before $\mathbf{4 a}$.

\section{ASSOCIATED CONTENT}

\section{Supporting Information}

The Supporting Information is available free of charge on the ACS Publications website at DOI: 10.1021/acs.jmedchem.5b01812.

Revised pharmacophore model for 3,4-disubstituted $\beta$-lactam-based MGL inhibitors, HPLC separation of racemic mixture $( \pm)-6 a$, top-down and bottom-up 
proteomics studies, pharmacokinetic profiling of $4 a$, analgesic effect of $\mathbf{4 a}$ in the mouse hot plate test, determination of the absolute configuration of $(3 R, 4 S)$ 6a, ${ }^{1} \mathrm{H}$ and ${ }^{13} \mathrm{C}$ NMR spectra of compounds $( \pm)-4 a$, $( \pm)-5 a$, and $( \pm)-6 a$, elemental analysis results for tested compounds (PDF)

Molecular formula strings (CSV)

\section{AUTHOR INFORMATION}

\section{Corresponding Author}

*Phone: 390577 234172. Fax: 390577 234333. E-mail: campiani@unisi.it.

\section{Notes}

The authors declare no competing financial interest.

\section{ACKNOWLEDGMENTS}

DFT and TD-DFT calculations for the stereochemical characterization of (+)-trans-6a were carried out on the computing cluster of Prof. R. Zanasi's research group (Department of Chemistry and Biology, University of Salerno, Italy). We are grateful to Dr. M. Allarà and Dr. V. Palmieri for assistance in the in vitro bioassays.

\section{ABBREVIATIONS USED}

ABHD6, abhydrolase domain-containing protein 6; ABHD12, abhydrolase domain-containing protein 12; ABPP, affinity-based proteomic profiling; AEA, anandamide; 2-AG, 2-arachidonoylsn-glycerol; $\mathrm{CB}$, cannabinoid; CBRs, cannabinoid receptors; $\mathrm{CPP}$, coronary perfusion pressure; dpi, days postimmunization; DCM, dichloromethane; N,N-DIPEA, diisopropylethylamine; DMAP, 4-dimethylaminopyridine; ECG, electrocardiogram; ECD, electronic circular dichroism; ECs, endocannabinoids; EAE, experimental autoimmune encephalomyelitis; FAAH, fatty acid amide hydrolase; $h \mathrm{FAAH}$, humanFAAH; GB/SA, generalized-Born/surface area; IPTG, isopropyl- $\beta$-D-thiogalactopyranoside; LVP, left ventricle pressure; LC-MS, liquid chromatography/atmospheric pressure chemical ionization/mass spectrometry; LFB, Luxol Fast Blue; LYPLA1/2, lysophopholipase A1/2; MGL, monoacylglycerol lipase; hMGL, human MGL; $r$ MGL, rat MGL; MS, multiple sclerosis; $\mathrm{MOG}_{35-55}$, myelin glycoprotein 35-55; OPLS-AA, optimized potentials for liquid simulations-all atom; OXP, oxaliplatin; PRCG, Polak-Ribiere conjugate gradient; SDS-PAGE, sodium dodecyl sulfate polyacrylamide gel electrophoresis; THF, tetrahydrofuran; TLC, thin layer chromatography; TD-DFT, time-dependent density functional theory; TEA, triethylamine

\section{REFERENCES}

(1) Bhat, R.; Steinman, L. Innate and adaptive autoimmunity directed to the central nervous system. Neuron 2009, 64, 123-132.

(2) Di Marzo, V.; Stella, N.; Zimmer, A. Endocannabinoid signalling and the deteriorating brain. Nat. Rev. Neurosci. 2015, 16, 30-42.

(3) Bisogno, T.; Di Marzo, V. Cannabinoid receptors and endocannabinoids: role in neuroinflammatory and neurodegenerative disorders. CNS Neurol. Disord.: Drug Targets 2010, 9, 564-573.

(4) Hauser, S. L.; Chan, J. R.; Oksenberg, J. R. Multiple sclerosis: Prospects and promise. Ann. Neurol. 2013, 74, 317-327.

(5) Lublin, F. D.; Reingold, S. C.; Cohen, J. A.; Cutter, G. R.; Sorensen, P. S.; Thompson, A. J.; Wolinsky, J. S.; Balcer, L. J.; Banwell, B.; Barkhof, F.; Bebo, B., Jr.; Calabresi, P. A.; Clanet, M.; Comi, G.; Fox, R. J.; Freedman, M. S.; Goodman, A. D.; Inglese, M.; Kappos, L.; Kieseier, B. C.; Lincoln, J. A.; Lubetzki, C.; Miller, A. E.; Montalban, X.; O'Connor, P. W.; Petkau, J.; Pozzilli, C.; Rudick, R. A.; Sormani, M. P.; Stuve, O.;
Waubant, E.; Polman, C. H. Defining the clinical course of multiple sclerosis: the 2013 revisions. Neurology 2014, 83, 278-286.

(6) Deshmukh, V. A.; Tardif, V.; Lyssiotis, C. A.; Green, C. C.; Kerman, B.; Kim, H. J.; Padmanabhan, K.; Swoboda, J. G.; Ahmad, I.; Kondo, T.; Gage, F. H.; Theofilopoulos, A. N.; Lawson, B. R.; Schultz, P. G.; Lairson, L. L. A regenerative approach to the treatment of multiple sclerosis. Nature 2013, 502, 327-332.

(7) Mackie, K. Cannabinoid receptors: where they are and what they do. J. Neuroendocrinol. 2008, 20 (Suppl s1), 10-14.

(8) Di Marzo, V.; Petrosino, S. Endocannabinoids and the regulation of their levels in health and disease. Curr. Opin. Lipidol. 2007, 18, 129-140.

(9) Labar, G.; Bauvois, C.; Borel, F.; Ferrer, J. L.; Wouters, J.; Lambert, D. M. Crystal structure of the human monoacylglycerol lipase, a key actor in endocannabinoid signaling. ChemBioChem 2010, 11, 218-227.

(10) Hohmann, A. G.; Suplita, R. L.; Bolton, N. M.; Neely, M. H.; Fegley, D.; Mangieri, R.; Krey, J. F.; Walker, J. M.; Holmes, P. V.; Crystal, J. D.; Duranti, A.; Tontini, A.; Mor, M.; Tarzia, G.; Piomelli, D. An endocannabinoid mechanism for stress-induced analgesia. Nature 2005, 435, 1108-1112.

(11) Makara, J. K.; Mor, M.; Fegley, D.; Szabo, S. I.; Kathuria, S.; Astarita, G.; Duranti, A.; Tontini, A.; Tarzia, G.; Rivara, S.; Freund, T. F.; Piomelli, D. Selective inhibition of 2-AG hydrolysis enhances endocannabinoid signaling in hippocampus. Nat. Neurosci. 2005, 8, 1139-1141.

(12) King, A. R.; Duranti, A.; Tontini, A.; Rivara, S.; Rosengarth, A.; Clapper, J. R.; Astarita, G.; Geaga, J. A.; Luecke, H.; Mor, M.; Tarzia, G.; Piomelli, D. URB602 inhibits monoacylglycerol lipase and selectively blocks 2-arachidonoylglycerol degradation in intact brain slices. Chem. Biol. 2007, 14, 1357-1365.

(13) Bisogno, T.; Ortar, G.; Petrosino, S.; Morera, E.; Palazzo, E.; Nalli, M.; Maione, S.; Di Marzo, V. Development of a potent inhibitor of 2arachidonoylglycerol hydrolysis with antinociceptive activity in vivo. Biochim. Biophys. Acta, Mol. Cell Biol. Lipids 2009, 1791, 53-60.

(14) Long, J. Z.; Li, W.; Booker, L.; Burston, J. J.; Kinsey, S. G.; Schlosburg, J. E.; Pavon, F. J.; Serrano, A. M.; Selley, D. E.; Parsons, L. H.; Lichtman, A. H.; Cravatt, B. F. Selective blockade of 2arachidonoylglycerol hydrolysis produces cannabinoid behavioral effects. Nat. Chem. Biol. 2009, 5, 37-44.

(15) Hoornaert, C., Triazolopyridine carboxamide derivatives, preparation thereof and therapeutic use thereof. PCT Int. Appl. WO 2008145842, 2008.

(16) Aaltonen, N.; Savinainen, J. R.; Ribas, C. R.; Ronkko, J.; Kuusisto, A.; Korhonen, J.; Navia-Paldanius, D.; Hayrinen, J.; Takabe, P.; Kasnanen, H.; Pantsar, T.; Laitinen, T.; Lehtonen, M.; PasonenSeppanen, S.; Poso, A.; Nevalainen, T.; Laitinen, J. T. Piperazine and piperidine triazole ureas as ultrapotent and highly selective inhibitors of monoacylglycerol lipase. Chem. Biol. 2013, 20, 379-390.

(17) Ransohoff, R. M. Animal models of multiple sclerosis: the good, the bad and the bottom line. Nat. Neurosci. 2012, 15, 1074-1077.

(18) Hart, D. J.; Ha, D. C. The ester enolate imine condensation route to beta-lactams. Chem. Rev. 1989, 89, 1447-1465.

(19) Morrill, L. C.; Douglas, J.; Lebl, T.; Slawin, A. M. Z.; Fox, D. J.; Smith, A. D. Isothiourea-mediated asymmetric Michael-lactonisation of trifluoromethylenones: a synthetic and mechanistic study. Chem. Sci. 2013, 4, 4146-4155.

(20) Smith, S. R.; Douglas, J.; Prevet, H.; Shapland, P.; Slawin, A. M.; Smith, A. D. Isothiourea-catalyzed asymmetric synthesis of beta-lactams and beta-amino esters from arylacetic acid derivatives and $\mathrm{N}$ sulfonylaldimines. J. Org. Chem. 2014, 79, 1626-1639.

(21) Autschbach, J. Computing chiroptical properties with firstprinciples theoretical methods: background and illustrative examples. Chirality 2009, 21, E116-E152.

(22) Bertrand, T.; Auge, F.; Houtmann, J.; Rak, A.; Vallee, F.; Mikol, V.; Berne, P. F.; Michot, N.; Cheuret, D.; Hoornaert, C.; Mathieu, M. Structural basis for human monoglyceride lipase inhibition. J. Mol. Biol. 2010, 396, 663-673.

(23) Jones, G.; Willett, P.; Glen, R. C. Molecular recognition of receptor sites using a genetic algorithm with a description of desolvation. J. Mol. Biol. 1995, 245, 43-53. 
(24) Brindisi, M.; Butini, S.; Franceschini, S.; Brogi, S.; Trotta, F.; Ros, S.; Cagnotto, A.; Salmona, M.; Casagni, A.; Andreassi, M.; Saponara, S.; Gorelli, B.; Weikop, P.; Mikkelsen, J. D.; Scheel-Kruger, J.; SandagerNielsen, K.; Novellino, E.; Campiani, G.; Gemma, S. Targeting dopamine D3 and serotonin 5-HT1A and 5-HT2A receptors for developing effective antipsychotics: synthesis, biological characterization, and behavioral studies. J. Med. Chem. 2014, 57, 9578-9597.

(25) Di Prisco, S.; Merega, E.; Milanese, M.; Summa, M.; Casazza, S.; Raffaghello, L.; Pistoia, V.; Uccelli, A.; Pittaluga, A. CCL5-glutamate interaction in central nervous system: Early and acute presynaptic defects in EAE mice. Neuropharmacology 2013, 75, 337-346.

(26) Gold, R.; Hartung, H. P.; Toyka, K. V. Animal models for autoimmune demyelinating disorders of the nervous system. Mol. Med. Today 2000, 6, 88-91.

(27) Gatley, S. J.; Gifford, A. N.; Volkow, N. D.; Lan, R.; Makriyannis, A. 123I-labeled AM251: a radioiodinated ligand which binds in vivo to mouse brain cannabinoid CB1 receptors. Eur. J. Pharmacol. 1996, 307, 331-338.

(28) Hosohata, K.; Quock, R. M.; Hosohata, Y.; Burkey, T. H.; Makriyannis, A.; Consroe, P.; Roeske, W. R.; Yamamura, H. I. AM630 is a competitive cannabinoid receptor antagonist in the guinea pig brain. Life Sci. 1997, 61, PL115-118.

(29) Piscitelli, F.; Di Marzo, V. "Redundancy" of endocannabinoid inactivation: new challenges and opportunities for pain control. ACS Chem. Neurosci. 2012, 3, 356-363.

(30) Di Cesare Mannelli, L.; Pacini, A.; Bonaccini, L.; Zanardelli, M.; Mello, T.; Ghelardini, C. Morphologic features and glial activation in rat oxaliplatin-dependent neuropathic pain. J. Pain 2013, 14, 1585-1600.

(31) Jung, K. M.; Sepers, M.; Henstridge, C. M.; Lassalle, O.; Neuhofer, D.; Martin, H.; Ginger, M.; Frick, A.; Dipatrizio, N. V.; Mackie, K.; Katona, I.; Piomelli, D.; Manzoni, O. J. Uncoupling of the endocannabinoid signalling complex in a mouse model of fragile $\mathrm{X}$ syndrome. Nat. Commun. 2012, 3, 1080.

(32) Baker, D.; Pryce, G.; Croxford, J. L.; Brown, P.; Pertwee, R. G.; Makriyannis, A.; Khanolkar, A.; Layward, L.; Fezza, F.; Bisogno, T.; Di Marzo, V. Endocannabinoids control spasticity in a multiple sclerosis model. FASEB J. 2000, 15, 300-302.

(33) Goerigk, L.; Grimme, S. Efficient and accurate double-hybridmeta-GGA density functionals-evaluation with the extended GMTKN30 database forgeneral main group thermochemistry, kinetics, and noncovalent interactions. J. Chem. Theory Comput. 2011, 7, 291-309.

(34) Halgren, T. A. MMFF VI. MMFF94s option for energy minimization studies. J. Comput. Chem. 1999, 20, 720-729.

(35) Grimme, S. Semiempirical GGA-type density functional constructed with a long-range dispersion correction. J. Comput. Chem. 2006, 27, 1787-1799.

(36) Tomasi, J.; Mennucci, B.; Cammi, R. Quantum mechanical continuum solvation models. Chem. Rev. 2005, 105, 2999-3093.

(37) Perdew, J. P.; Burke, K.; Ernzerhof, M. Generalized gradient approximation made simple. Phys. Rev. Lett. 1996, 77, 3865-3868.

(38) Adamo, C.; Barone, V. Toward reliable density functional methods without adjustable parameters: The PBE0 model. J. Chem. Phys. 1999, 110, 6158-6170.

(39) Stephens, P. J.; Harada, N. ECD cotton effect approximated by the Gaussian curve and other methods. Chirality 2010, 22, 229-233.

(40) Jorgensen, W. L.; Maxwell, D. S.; TiradoRives, J. Development and testing of the OPLS all-atom force field on conformational energetics and properties of organic liquids. J. Am. Chem. Soc. 1996, 118, $11225-11236$.

(41) Still, W. C.; Tempczyk, A.; Hawley, R. C.; Hendrickson, T. Semianalytical treatment of solvation for molecular mechanics and dynamics. J. Am. Chem. Soc. 1990, 112, 6127-6129.

(42) Schalk-Hihi, C.; Schubert, C.; Alexander, R.; Bayoumy, S.; Clemente, J. C.; Deckman, I.; DesJarlais, R. L.; Dzordzorme, K. C.; Flores, C. M.; Grasberger, B.; Kranz, J. K.; Lewandowski, F.; Liu, L.; Ma, H.; Maguire, D.; Macielag, M. J.; McDonnell, M. E.; Mezzasalma Haarlander, T.; Miller, R.; Milligan, C.; Reynolds, C.; Kuo, L. C. Crystal structure of a soluble form of human monoglyceride lipase in complex with an inhibitor at 1.35 A resolution. Protein Sci. 2011, 20, 670-683.
(43) Mileni, M.; Garfunkle, J.; Ezzili, C.; Cravatt, B. F.; Stevens, R. C.; Boger, D. L. Fluoride-mediated capture of a noncovalent bound state of a reversible covalent enzyme inhibitor: X-ray crystallographic analysis of an exceptionally potent alpha-ketoheterocycle inhibitor of fatty acid amide hydrolase. J. Am. Chem. Soc. 2011, 133, 4092-4100.

(44) (a) Butini, S.; Brindisi, M.; Gemma, S.; Minetti, P.; Cabri, W.; Gallo, G.; Vincenti, S.; Talamonti, E.; Borsini, F.; Caprioli, A.; Stasi, M. A.; Di Serio, S.; Ros, S.; Borrelli, G.; Maramai, S.; Fezza, F.; Campiani, G.; Maccarrone, M. Discovery of potent inhibitors of human and mouse fatty acid amide hydrolases. J. Med. Chem. 2012, 55, 6898-6915. (b) Butini, S.; Gemma, S.; Brindisi, M.; Maramai, S.; Minetti, P.; Celona, D.; Napolitano, R.; Borsini, F.; Cabri, W.; Fezza, F.; Merlini, L.; Dallavalle, S.; Campiani, G.; Maccarrone, M. Identification of a novel arylpiperazine scaffold for fatty acid amide hydrolase inhibition with improved drug disposition properties. Bioorg. Med. Chem. Lett. 2013, 23, 492-495.

(45) Verdonk, M. L.; Cole, J. C.; Hartshorn, M. J.; Murray, C. W.; Taylor, R. D. Improved protein-ligand docking using GOLD. Proteins: Struct. Funct. Genet. 2003, 52, 609-623.

(46) Chang, J. W.; Niphakis, M. J.; Lum, K. M.; Cognetta, A. B., 3rd; Wang, C.; Matthews, M. L.; Niessen, S.; Buczynski, M. W.; Parsons, L. H.; Cravatt, B. F. Highly selective inhibitors of monoacylglycerol lipase bearing a reactive group that is bioisosteric with endocannabinoid substrates. Chem. Biol. 2012, 19, 579-588.

(47) Chang, J. W.; Cognetta, A. B., 3rd; Niphakis, M. J.; Cravatt, B. F. Proteome-wide reactivity profiling identifies diverse carbamate chemotypes tuned for serine hydrolase inhibition. ACS Chem. Biol. 2013, 8, $1590-1599$.

(48) Gemma, S.; Camodeca, C.; Sanna Coccone, S.; Joshi, B. P.; Bernetti, M.; Moretti, V.; Brogi, S.; Bonache de Marcos, M. C.; Savini, L.; Taramelli, D.; Basilico, N.; Parapini, S.; Rottmann, M.; Brun, R.; Lamponi, S.; Caccia, S.; Guiso, G.; Summers, R. L.; Martin, R. E.; Saponara, S.; Gorelli, B.; Novellino, E.; Campiani, G.; Butini, S. Optimization of 4-aminoquinoline/clotrimazole-based hybrid antimalarials: further structure-activity relationships, in vivo studies, and preliminary toxicity profiling. J. Med. Chem. 2012, 55, 6948-6967.

(49) Cecchelli, R.; Aday, S.; Sevin, E.; Almeida, C.; Culot, M.; Dehouck, L.; Coisne, C.; Engelhardt, B.; Dehouck, M. P.; Ferreira, L. A stable and reproducible human blood-brain barrier model derived from hematopoietic stem cells. PLoS One 2014, 9, e99733.

(50) Lundquist, S.; Renftel, M.; Brillault, J.; Fenart, L.; Cecchelli, R.; Dehouck, M. P. Prediction of drug transport through the blood-brain barrier in vivo: a comparison between two in vitro cell models. Pharm. Res. 2002, 19, 976-981.

(51) Saponara, S.; Ferrara, A.; Gorelli, B.; Shah, A.; Kawase, M.; Motohashi, N.; Molnar, J.; Sgaragli, G.; Fusi, F. 3,5-dibenzoyl-4-(3phenoxyphenyl)-1,4-dihydro-2,6-dimethylpyridine (DP7): a new multidrug resistance inhibitor devoid of effects on Langendorff-perfused rat heart. Eur. J. Pharmacol. 2007, 563, 160-163.

(52) Ferrara, A.; Fusi, F.; Gorelli, B.; Sgaragli, G.; Saponara, S. Effects of freeze-dried red wine on cardiac function and ECG of the Langendorffperfused rat heart. Can. J. Physiol. Pharmacol. 2014, 92, 171-174.

(53) Abbott, F. V.; Franklin, K. B.; Westbrook, R. F. The formalin test: scoring properties of the first and second phases of the pain response in rats. Pain 1995, 60, 91-102.

(54) Marsicano, G.; Wotjak, C. T.; Azad, S. C.; Bisogno, T.; Rammes, G.; Cascio, M. G.; Hermann, H.; Tang, J.; Hofmann, C.; Zieglgansberger, W.; Di Marzo, V.; Lutz, B. The endogenous cannabinoid system controls extinction of aversive memories. Nature 2002, 418, 530-534.

(55) Andre, T.; Boni, C.; Mounedji-Boudiaf, L.; Navarro, M.; Tabernero, J.; Hickish, T.; Topham, C.; Zaninelli, M.; Clingan, P.; Bridgewater, J.; Tabah-Fisch, I.; de Gramont, A. Oxaliplatin, fluorouracil, and leucovorin as adjuvant treatment for colon cancer. N. Engl. J. Med. 2004, 350, 2343-2351.

(56) Kannarkat, G.; Lasher, E. E.; Schiff, D. Neurologic complications of chemotherapy agents. Curr. Opin. Neurol. 2007, 20, 719-725.

(57) Cavaletti, G.; Tredici, G.; Petruccioli, M. G.; Donde, E.; Tredici, P.; Marmiroli, P.; Minoia, C.; Ronchi, A.; Bayssas, M.; Griffon Etienne, 
G. Effects of different schedules of oxaliplatin treatment on the peripheral nervous system of the rat. Eur. J. Cancer 2001, 37, 2457-2463.

(58) O'Callaghan, J. P.; Holtzman, S. G. Quantification of the analgesic activity of narcotic antagonists by a modified hot-plate procedure. $J$. Pharmacol. Exp. Ther. 1975, 192, 497-505.

(59) Di Prisco, S.; Merega, E.; Lanfranco, M.; Casazza, S.; Uccelli, A.; Pittaluga, A. Acute desipramine restores presynaptic cortical defects in murine experimental autoimmune encephalomyelitis by suppressing central CCL5 overproduction. Br. J. Pharmacol. 2014, 171, 2457-2467. 